
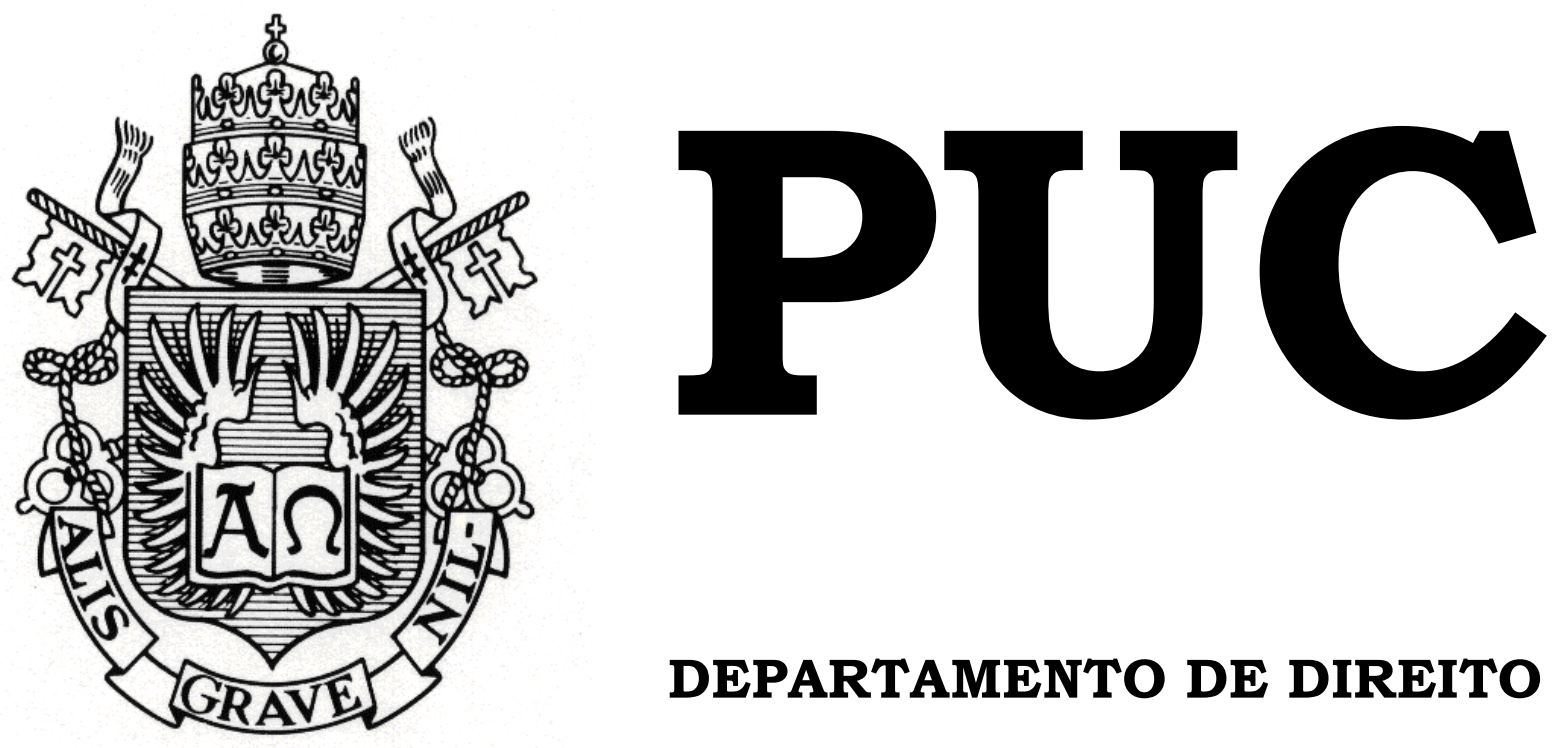

DEPARTAMENTO DE DIREITO

\title{
A JURISDICIZAÇÃO DO AFETO E A RESPONSABILIDADE CIVIL POR ABANDONO AFETIVO
}

por

GIULIA RABE BENNESBY

Orientador: MARCELO JUNQUEIRA CALIXTO

2015.2

PONTIFÍCIA UNIVERSIDADE CATÓLICA DO RIO DE JANEIRO

RUA MARQUÊS DE SÃO VICENTE, 225 - CEP 22453-900

RIO DE JANEIRO - BRASIL 


\title{
A JURISDICIZAÇÃO DO AFETO E A RESPONSABILIDADE CIVIL POR ABANDONO AFETIVO
}

\author{
por \\ GIULIA RABE BENNESBY \\ Monografia apresentada ao \\ Departamento de Direito da \\ Pontificia Universidade \\ Católica do Rio de Janeiro \\ (PUC-Rio) como requisito \\ para a obtenção do Título \\ de Bacharel em Direito.
}

Orientador: Marcelo Junqueira Calixto 


\section{AGRADECIMENTOS}

Agradeço primeiramente a Deus, o principal guia dos meus passos. Junto a ele, agradeço aos meus pais, Dreyfus e Merisa, por todo o carinho, amor, paciência e por não medirem esforços para que possa chegar o mais perto dos meus sonhos. Bem como aos meus quatro avós Moises, Olinda, Mery Eliza e Isaac, pelos exemplos de vida e dedicação, ao qual sempre me espelhei, refletindo a batalha da vida e que é preciso lutar para vencer.

Agradeço também aos meus irmãos, Nathan e Daniel, que são, indubitavelmente, meus melhores e mais fiéis companheiros de vida. Sempre estiveram comigo e são minha certeza do para sempre.

Ao meu querido namorado, Felipe, pelo eterno incentivo e, principalmente, pelo incomparável apoio diário nas escolhas que devo tomar.

Aos amigos que construí ao longo de minha vida, que são, indubitavelmente, a família que escolhi. Aos amigos desde o colégio e à todos os queridos amigos que fiz durante os cinco maravilhosos anos na faculdade.

À todos os professores, pela dedicação demonstrada ao longo dos cinco anos de curso. Em especial aos professores que lecionam nas aulas das sete da manhã que esboçavam sorrisos e empenho mesmo em horários nem sempre tão agradáveis.

Por fim, agradeço a meu Orientador neste trabalho, Marcelo Junqueira Calixto, por todo empenho, atenção e dedicação, durante o tempo de orientação e, muito além disso, por me fazer acreditar que o magistério é incomparável eme criar um novo sonho: o de dar aula na Universidade que me formou. 


\section{RESUMO}

BENNESBY, Giulia Rabe. A JURISDICIZAÇÃO DO AFETO E A RESPONSABILIDADE CIVIL POR ABANDONO AFETIVO. Rio de Janeiro, 2015. 125 p. Monografia de final de curso - Departamento de Direito, Pontifícia Universidade Católica do Rio de Janeiro.

O presente trabalho tem por objetivoimpulsionar e perfazer uma reflexão ponderada e criteriosa do que se entende por abandono afetivo e a forma pela qual a doutrina e a jurisprudência se comportam em relação as consequências a que devemsofrer os pais em caso de inobservância dos deveres jurídicos decorrentes do poder familiar. Nesse sentido, o presente trabalho visa o estudo da responsabilidade civil no âmbito das relações familiares, a fim de que se conheça as possíveisimplicações jurídicas acarretadas pelo abandono afetivo.

Para tanto, analisar-se-ãoas peculiaridadesda responsabilidade civil aplicada ao direito de família, bem como suasrepercussões na atual jurisprudência dos tribunais.

Em busca do alcance do objetivo proposto pelo trabalho, será realizada uma investigação acerca da jurisdicização e a patrimonialização do afeto a fim de que se enfrente a problemática da conduta do abandono afetivo, através de uma perspectiva jurídica singular.

Além disso, abordar-se-ão, a partir de uma visão interdisciplinar, temas da psicanálise para que sejam estabelecidos os pontos de encontro e de ruptura entre o direito e a psicanálise, estabelecendo marcos importantes de ambas as áreas do saber.

Palavras chave:Direito Civil. Direito de Família. Responsabilidade civil. Abandono afetivo. Jurisdicização do afeto. Patrimonialização do afeto. Direito e Psicanálise. Ética. 


\section{SUMÁRIO}

INTRODUÇÃO .............................................................................................. 7

Capítulo I - ABANDONO AFETIVO _...............................................9

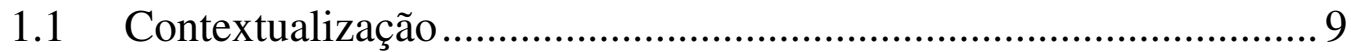

1.1.1 Conceito e Reflexos Jurídicos ................................................. 13

1.1.2 Princípio da Afetividade como Direito Fundamental da

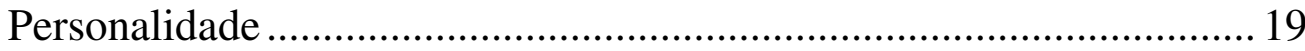

1.1.3 Princípio da Paternidade Responsável como Obrigação Legal da Família 25

1.1.4 Dos Maus Tratos à Ausência de Trato ..................................... 27

1.2 A Jurisdicização do Afeto ................................................................. 29

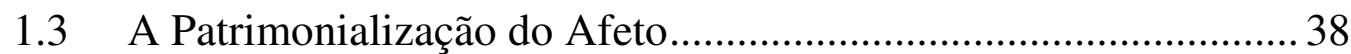

$\begin{array}{lllll}\text { Capítulo II } & - & \text { NOÇÕES FUNDAMENTAIS DE }\end{array}$ RESPONSABILIDADE CIVIL E SUA APLICAÇÃO NAS RELAÇÕES FAMILIARES................................................................... 42

2.1 A Evolução da Responsabilidade Civil nas Relações Familiares.. 42

2.2 Pressupostos Gerais da Responsabilidade Civil ............................. 45

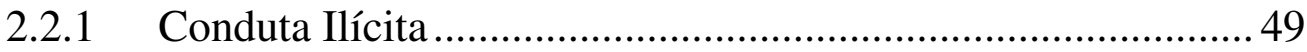

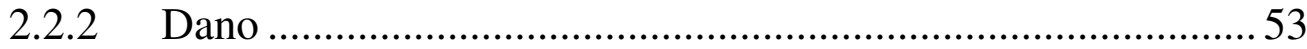

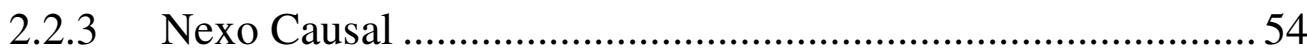

Capítulo III - A RESPONSABILIDADE POR ABANDONO

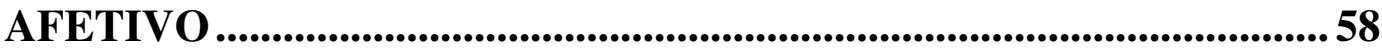

3.1 A Intervenção Estatal nas Relações Familiares ...............................58

3.2 A Espécie de Responsabilidade Civil Aplicável aos Casos de Abandono Afetivo 65

3.3 O Alcance da Responsabilidade Civil nas Relações do Abandono Afetivo pela Parentalidade: da Perda do Poder Familiar à Indenização

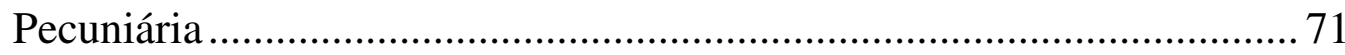

3.3.1 Indenização Cível: a Resposta do Poder Judiciário .................. 73 
3.3.2 Punição Criminal: Tentativa Louvável de Esforço pelo Poder

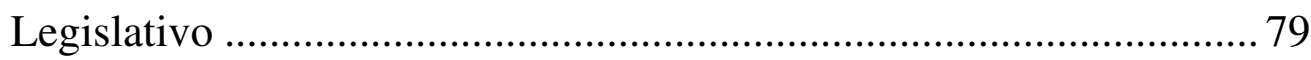

3.4 Comentários ao REsp. 11.59242/SP que Reconheceu a Procedência do Pedido de Indenização por Abandono Afetivo ....................................... 85

3.5 Mediação como Modo Mais Efetivo para a Solução do Conflito .91

Capítulo IV - DIREITO E PSICANÁLISE ..............................................98

4.1 O Interesse da Psicanálise para o Direito: Uma Visão

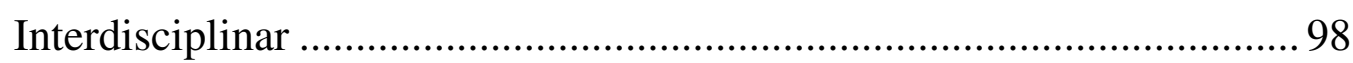

4.2 A Proposta da Psicanálise: a Subjetivação da Responsabilidade 102

4.3 A Ética Afetiva como Limite à Conduta Humana........................ 105

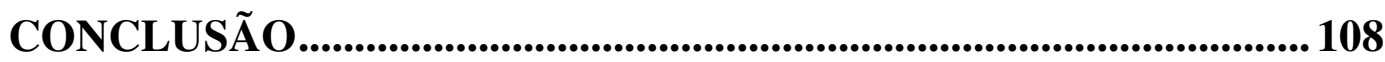

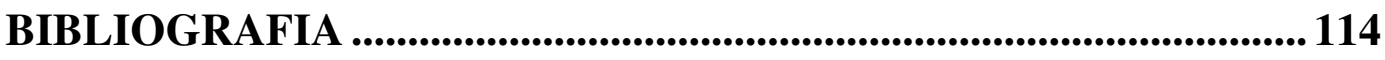




\section{LISTA DE ABREVIAÇÕES}
Art. -
Artigo
CRFB -
Constituição da República Federativa do Brasil
$\mathrm{CPC}-$
Código de Processo Civil
Des. - Desembargador
ECA - $\quad$ Estatuto da Criança e do Adolescente
IBDFAM - Instituo Brasileiro de Direito de Família
Inc. - Inciso
j. - Julgado
Min. - $\quad$ Ministro
p. - página
PL - $\quad$ Projeto de lei
Rel. - $\quad$ Relator
REsp - Recurso Especial
STF - $\quad$ Supremo Tribunal Federal
STJ - $\quad$ Superior Tribunal de Justiça 


\section{INTRODUÇÃO}

Ao Judiciário sempre se foi indagado quanto a possibilidade da responsabilização civil no âmbito das relações paterno-filiais e, por se mostrar um tema polêmico e muito instigante, esse será o objeto de discussão no presente trabalho.

O afeto, apesar de sempre conhecida a sua importância para o desenvolvimento do indivíduo, passou a ser encarado como fundamental dentro núcleo familiar, se configurando como um princípio constitucional e um dever decorrente do poder familiar. Tal cenário é resultado do entendimento de que o afeto é o meio capaz de fornecer a possibilidade de formação da individualidade e o contexto propício para o efetivo crescimento do sujeito. Assim, o ambiente familiar unido do afeto se revela como o único meio no qual a pessoa se sente livre para se tornar naquilo que seus desejos mais íntimos esperam.

Sobre o tema, CARLOS ROBERTO GONÇALVES explica que além do zelo material, a assistência moral se mostra como de extrema relevância para a formação do espírito e do caráter da prole:

\footnotetext{
O dever de dirigir a criação e educação dos filhos menores é o mais importante de todos. Incumbe aos pais velar não só pelo sustento dos filhos, como pela sua formação, a fim de torná-los úteis a si, à família e à sociedade. O encargo envolve, pois, além do zelo material, para que o filho fisicamente sobreviva, também o moral, para que, por meio da educação, forme seu espírito e seu caráter. ${ }^{1}$
}

Neste diapasão, diante da relevância do tema, a exposição do texto se dará dividido em quatrocapítulos. No primeiro, realizar-se-á uma digressão contextual acerca do abandono afetivo, demonstrandocomo o abandono sempre esteve presente na história da humanidade. Posteriormente, se 
alcançará o conceito de abandono afetivo e os reflexos jurídicos de tal conduta.

Explicar-se-á a importância da afetividade para o núcleo familiar e para o desenvolvimento do indivíduo, estabelecendo a afetividade como princípio previsto na Carta Magna e como direito fundamental da pessoa humana. Para tanto, a jurisdicização e a patrimonialização do afeto serão abordados de forma criteriosa, enfrentando a sua problemática.

O próximo passo, presente no capítulo II, será apresentar as noções fundamentais da responsabilidade civil e a sua evolução quando aplicada às relações familiares.

Uma vez expostas tais premissas básicas, passarão a ser enfrentadas, no capítulo III, as problemáticas da intervenção estatal no âmbito familiar, bem como a espécie e o alcance da responsabilidade civil nas relações de abandono afetivo. No mesmo capítulo, serão apresentados comentários ao Recurso Especial paradigma do tema, o qual previu a possibilidade de fixação do quantum indenizatório ao filho que sofreu a desassistência afetiva. Será, ainda, feita a apresentação da via mais efetiva para a solução do conflito existente nos casos de abandono afetivo, já que se mostra necessário o estudo da eficiência do Poder Judiciário para a resolução de tais conflitos.

Por fim, para ilustrar o tema, será feito um estudo interdisciplinar entre o Direito e a Psicanálise, por ser essa última intimamente ligada ao estudo dos problemas subjetivos e internos dos seres humanos. Para tanto, será apresentado o interesse da Psicanálise para o Direito, bem como a exposição da proposta da Psicanálise para a responsabilidade dos indivíduos por seus atos. Por último, será estabelecida uma relação de dependência entre a ética afetiva e o limite à conduta humana, a fim de que se observe a importância da doação dos pais aos seus filhos. 


\section{Capítulo I - ABANDONO AFETIVO}

\subsection{Contextualização}

O Brasil é marcado pelo crescente número de casos de negligência infanto-juvenil e de casos de abandono pelos seus familiares. O Estado, diante da falta de politicas públicas, começa a esboçar, através do Poder Judiciário, a tentativa de reparação pela falta do convívio com suas famílias.

O abandono familiar é, assim, um problema social, onde a invisibilidade das crianças e adolescentes abandonados acarreta graves consequências emocionais, contribuindo para uma má formação do indivíduo como um ser particular.

Não são raros os noticiários que narram casos que vão desde abandono derecém-nascidos emlixos das ruas até a retirada de adolescentes do ambiente familiar pelos órgãos de proteção à criança. A retirada do convívio do ambiente familiar se dá por motivos como a negligência familiar, a violênciadoméstica, destacando os abusos físicos e sexuais que acometem crianças e adolescentes, se mostrando necessário queessacriança ou o adolescente seja retirado do ambiente familiar e encaminhado para uma casa de abrigo que possa dar suporte as suas necessidades físicas, emocionais e capaz de abriga-los.

Apesar de casos de abandono de filhos estamparem cotidianamente as páginas da imprensa atual, o abandono, em geral, não é fenômeno exclusivo da atualidade. Ocorre em todos os tempos, lugares, classes sociais e situações financeiras das mais variadas.

O Código de Hamurabi, datado do $2^{\circ}$ milênio a.C., regulamentava o abandono de crianças, bem como, na Roma Antiga, o pai detinha do poder sobre a vida deu seus filhos, podendo, inclusive lhes decretar a morte.

Na mitologia grega, por sua vez, não são raros as personagens que protagonizam seus destinos trágicos em decorrência do abandono. Um dos 
maiores e mais conhecidos exemplos é a história de Édipo. Édipo foi abandonado por seus pais Laio e Jocasta, após uma tentativa frustrada de assassinato, cujo mito serviu para Freud estruturar e demonstrar o complexo das relações psíquicas originadas da relação triangular mãe-filho-pai. Outros mitos gregos como Júpiter - o Deus da luz, os gêmeos Zeto e Anfion, Poseidon - o Deus da água, Hércules e a deusa Cibele, todos sofreram o abandono.

Na Torá, a bíblia dos judeus, há também passagens de Ismael (Ishmael), filho de Abrão (Avraham), que fora abandonado no deserto e salvo por Deus, bem como há a história de Moises (Moshe), que segundo os registros bíblicos, fora abandonado por sua mãe Tzipora em um cesto no Rio Nilo para que fosse salvo.

Na Bíblia, na passagem Mateus 27:46, há o relato de que Jesus (Ioshua), já pregado na cruz e no auge de sua dor, questiona Deus, seu pai com as palavras "Eloki, Eloki, lamá sabactâni?" (Deus meu, Deus meu, por que me abandonaste?). Há, ainda, a passagem de José (Yossef), filho de Jacó (Yacov), que fora vendido pelos seus próprios irmãos para o Egito.

Desse modo, tanto a Torá como o Talmud (textos que explicam a Torá) trataram do abandono, conferindo poder ao pai inclusive de vender o filho caso entendesse necessário.

No Brasil, a cultura do abandono tem origem na colonização, uma vez que não há quaisquer provas de que os índios que aqui habitavam detinham, como costume, o abandono de suas crianças. Há relatos que, pelo contrário, os indígenas que habitavam o Brasil mantinham uma relação de extrema afetividade com suas crianças, com fortes vínculos entre a tribo e o núcleo familiar. Por essa razão, pode-se dizer que o abandono se constitui por um fenômeno importado, conforme conclusão a que chegou a historiadora DIANE VALDEZ, em seu estudo intitulado "Inocentes Expostos: O abandono de crianças na Província de Goiás no século XIX”, o qual objetivou a análise do fenômeno do abandono na sociedade goiana no século XIX e a influência dos indígenas que habitava a região: 
A prática de abandonar crianças não é um fenômeno recente. No decorrer da história é notável como o abandono de crianças permeia diferentes sociedades por inúmeros motivos

(...)

O costume de abandonar filhos, prática bastante usual na Europa, como foi anotado neste trabalho, chegou ao Brasil com o processo de colonização. A colônia adotou a prática, antes não conhecida, pois não há nada que comprove o abandono de filhos por parte da sociedade indígena ou dos escravos provindos da África. ${ }^{2}$

O abandono é encarado como uma forma grave de descuido, que gera o rompimento de um vínculo entre pai e filho, submetendo às vitimas de abandono a sofrimentos físicos e psíquicos influenciando em seu comportamento e atitudes ao longo de toda sua vida.

O ECA "situa a família como célula estrutural da sociedade e reforça a importância do vínculo familiar como fundamental no desenvolvimento da criança e adolescente, em consonância com as teorias psicológicas",3

Assim, a família tem grande influência na formação de um indivíduo, e o abandono é capaz de interromper ou estragar o bom desenvolvimento do caráter.

O sentimento de abandono, por ser tão amplo e profundo, perpassa a historia do homem e se coloca em sua subjetividade, podendo se manifestar desde a angustia de ter sido esquecido no colégio até a necessidade de um olhar de amparo e um aperto na mão.

\section{PAULO LÔBO ensina:}

Portanto, o "abandono afetivo" nada mais é que inadimplemento dos deveres jurídicos de paternidade. Seu campo não é exclusivamente o da moral, pois o direito o atraiu para si, conferindo-lhe consequências jurídicas que não podem ser desconsideradas.

Por isso, seria possível considerar a possibilidade da responsabilidade civil, para quem descumpre o múnus inerente ao poder familiar. "Afinal, se uma criança veio ao mundo - desejada ou não, planejada ou não — os pais devem arcar com a responsabilidade que esta escolha (consciente ou não) lhes demanda. ${ }^{4}$

\footnotetext{
${ }^{2}$ VALDEZ, Diane. Inocentes Expostos: O abandono de crianças na íncia de Goiás no século XIX. Rev. Fac. Educ. UFG, 29 (I), 2009. p. 107-113.

${ }^{3}$ MENDES. M. U. Vindo e Indo. In: MORATO, H. T. P; BARRETO, C. L. B. T; PRADO, A. N. Rio de Janeiro: Guanabara Koogan, 2009. cap.25. p.356-375

${ }^{4}$ LÔBO, Paulo. Direito civil: famílias. 4. ed. São Paulo: Saraiva, 2011. p.310-311
} 
Fato é que a família representa a célula essencial da sociedade, capaz de desenvolver valores éticos e morais do ser humano. Nessa esteira, o vínculo familiar é considerado de suma importância.

Cabe o destaque de o vínculo familiar não ser mais estabelecido apenas pelas relações de consanguinidade. A sociedade, por estar em constante transformação, além do aparecimento de novas formas de família, o vínculo afetivo tem prevalecido em detrimento ao vínculo puramente biológico, uma vez que a relação entre membros de uma família que se constitui pelo sangue não, obrigatoriamente, trazem consigo sentimentos saudáveis como o do amor, do respeito e da afetividade.

CODO e GAZZOTTI, ao observar a afetividade, a descrevem como o conjunto de:

(...) fenômenos psíquicos que se manifestam sob a forma de emoções, sentimentos e paixões, acompanhados sempre de impressão de dor ou prazer, de satisfação ou insatisfação, de agrado ou desagrado, de alegria ou de tristeza 5 .

Fato é que a afetividade pode ser considerada como uma construção cultural, com origens na convivência, desvinculada de quaisquer interesses materiais, que apenas surgem quando a tal afetividade se extingue.

A psicologia e a psicanálise são áreas do saber que estudam, como uma de suas vias de pesquisa, as consequências e os efeitos causados pelo abandono familiar em crianças e adolescentes. A psicologia entende que o abandono familiar é capaz de descontruir tudo que um sujeito acredita e confia, representando uma clara violação a sua dignidade como ser humano, lhe retirando o pilar de apoio que seria a sua família.

\footnotetext{
${ }^{5}$ CODO, W.; GAZZOTTI, A. A. Trabalho e afetividade. In: CODO, W. (Org.). Educação: carinho
} e trabalho. 3. ed. Petrópolis: Vozes, 1999, p.48-59 


\subsubsection{Conceito e Reflexos Jurídicos}

A bem da verdade, há que ser observada a existência de responsabilidade do Estado, da sociedade e da família, sobre os direitos e garantias das crianças e dos adolescentes.

É importante que cada membro da família cumpra seu dever, de modo que o afeto em favor dos membros familiares seja proporcionado como um dever de ordem moral, este que se violado vem a afrontar, sobretudo a ordem legal, em nível constitucional.

Não é desconhecida a importância do papel dos pais no crescimento e acompanhamento de seus filhos. O estágio de crescimento dos filhos é uma fase muito importante por ser a época na qual a criança forma o seu caráter e toda a sua estrutura emocional. $\mathrm{O}$ modo pelo qual os pais influenciam seus filhos na educação, na responsabilidade, no desenvolvimento psicológico, moral e afetivoacarretará na forma em que essas crianças irão se portar durante toda a sua vida, isto é, na fase adulta.

Fato é que toda criança deve receber amor, cuidado, afeto, carinho, incentivo, limites, educação e regras, para que não cresçam carentes, desamparadas e sem assistência.

A inércia, ou melhor, a omissão dos pais na criação e educação da prole reflete diretamente na sociedade, uma vez que, via de regra, filhos desamparados e que não receberam os devidos cuidados para uma vida digna, acabam por não se enquadrar na convivência social e, como uma consequência lógica, acabam por repetir os mesmos atos omissivos dos pais com seus futuros filhos, criando, assim, um ciclo vicioso.

É obvio que a Lei não obriga ninguém a amar ou proporcionar afeto aos filhos, porém enfatiza a obrigação de fornecimento de cuidados aos menores.

Ensinamentos de MONAGLE, citado por LIZETE PEIXOTO XAVIER SCHUH ${ }^{6}$, afirmam que apesar do papel dos pais ser difícil, se

${ }^{6}$ MONAGLE apud SCHUH, Lizete Peixoto Xavier. Responsabilidade civil por abandono afetivo: a valoração do elo perdido ou não consentido. Revista Brasileira de Direito de Família, Porto 
mostra como uma obrigação pela qual não há possibilidade de desoneração.

Um dos maiores desafios do século XXI é assegurar que as crianças cresçam transformando-se em adultos corretos e sábios. Sabe-se que são os pais responsáveis por essa tarefa árdua. Se a família é vista como o alicerce do grupo social, os pais são, portanto, como os primeiros professores das crianças, sendo essenciais para o desenvolvimento de uma pessoa saudável e equilibrada, que por sua vez exercerá a parentalidade com tranquilidade e segurança no futuro.

Conclui-se, assim, que a presença dos genitores além de ser para os filhos uma condição de desenvolvimento saudável e essencial para a formação de sua personalidade, é também vista pelo nosso ordenamento como responsabilidade legal dos genitores, de modo que haja a devida assistência estabelecida na Constituição Federal.

Três casos levados ao Judiciário marcaram a discussão sobre o tema. O primeiro caso, de Minas Gerais, versava sobre um pleito no qual o autor — que ingressou com a ação após a maioridade — afirmava que até os 6 anos manteve contato regular com seu pai. Posteriormente ao divórcio dos pais e o nascimento da irmã, fruto de novo relacionamento conjugal do pai, este se afastou definitivamente do filho, ainda que lhe pagando $20 \%$ de seus rendimentos líquidos, passando a tratá-lo com rejeição e frieza, inclusive em datas simbolicamente importantes, como aniversários, formaturas e aprovação em vestibular. Com fundamento nesses fatos e no art. 227 da Constituição, ingressou com ação por danos morais, julgada improcedente em primeira instância. O Tribunal de Justiça de origem acolheu apelação do filho, decidindo que " $a$ dor sofrida pelo filho, em virtude do abandono paterno, que o privou do direito à convivência, ao amparo afetivo, moral e psíquico, deve ser indenizável, com fulcro no princípio da dignidade da pessoa humana", fixando a indenização em 200 salários mínimos. O pai recorreu ao STJ (REsp 757.411) que, reformando a decisão recorrida por maioria, entendeu que "a indenização por dano moral pressupõe a prática de 
ato ilícito, não rendendo ensejo à aplicabilidade da norma do art. 159 do Código Civil de 1916 o abandono afetivo, incapaz de reparação pecuniária". Argumentou o relator que o descumprimento injustificado do dever de guarda, sustento e educação dos filhos leva à perda do poder familiar, como a mais grave pena civil a ser imputada a um pai; o voto vencido considerou que a perda do poder familiar não interfere na indenização por dano moral. O STF rejeitou o recurso extraordinário (RE 567.164), por entender que este é incabível para análise de indenização por danos morais.

O segundo caso, do Rio Grande do Sul, no ano de 2003, o juízo dos autos condenou um pai a pagar igualmente 200 salários mínimos à filha sob o fundamento de que "a educação abrange não somente a escolaridade, mas também a convivência familiar, o afeto, amor, carinho, ir ao parque, jogar futebol, brincar, passear, visitar, estabelecer paradigmas, criar condições para que a criança se autoafirme". A sentença transitou em julgado, por ter havido revelia.

Por fim, o terceiro caso, este de São Paulo, acarretou em uma sentença do juízo, prolatada em 2004, que acabou por condenar um pai a pagar indenização no valor de $\mathrm{R} \$ 50.000,00$ por danos morais e tratamento psicológico da filha. O pai havia abandonado sua filha com poucos meses de vida, quando se separou da mãe para constituir uma segunda família. A jovem abandonada sentiu-se rejeitada e humilhada em razão do tratamento frio dispensado a ela, especialmente por todos serem membros da colônia judaica, "crescendo envergonhada, tímida e embaraçada, com complexos de culpa e inferioridade", submetendo-se, por isso, a tratamento psicológico.

Os três supracitados casos se mostram como complexos, na medida em que pressupõeponderáveis reflexões de ambos os polos figurados pelas partes.Fica claro que o princípio da paternidade responsável,previsto no artigo 226 da Constituição, não pode ser resumido ao simples cumprimento do dever de assistência material, abrangendo, indubitavelmente, a 
assistência moral.

A assistência moral, por sua vez, deve ser considerada como um dever jurídico, cujo descumprimento acarretarána possibilidade da pretensão indenizatória. $\mathrm{O}$ art. 227 da Constituição confere à criança e ao adolescente os direitos "com absoluta prioridade", oponíveis à família, à vida, à saúde, à educação, ao lazer, à dignidade, ao respeito e à convivência familiar, que são direitos de conteúdo moral, integrantes da personalidade, cuja rejeição ou omissão provocará a pretensão indenizatória por dano morais.

Não custa lembrar que o poder familiar do pai separado não se finda com a separação, salvo no que concerne à guarda, permanecendo os deveres de criação, educação e companhia, previstos no art. 1.634 do Código Civil, que não se esgota na pensão alimentícia.

ROLF MADALENO explica que a guarda do menor em nada tem relação com o poder familiar, mantendo, por óbvio, todos os deveres do genitor mesmo após o divórcio.

A simples destituição da guarda física de filho pela separação dos pais não implica, sob nenhum aspecto a perda do poder familiar, e talvez até reforce o seu exercício pela redução do contato do genitor não-guardião com o seu filho que ficou sob a guarda do outro ascendente. Nem significa admitir sob qualquer pretexto, pudesse a cisão da guarda prejudicar por alguma forma o direito-dever dos genitores manterem uma sadia convivência familiar ${ }^{7}$.

Nessa esteira se encontra o dever jurídico dos genitores em fornecer todo o amparo decorrente da afetividade. LÔBO defende que "a afetividade é necessariamente presumida nas relações entre pais e filhos, ainda que na realidade da vida seja malferida, porque esse tipo de parentesco jamais se extingue." 8

\footnotetext{
${ }^{7}$ MADALENO, Rolf. A guarda compartilhada pela ótica dos direitos fundamentais. In, WELTER. Belmiro Pedro; MADALENO, Rolf (Coord). Direitos Fundamentais do Direito de Família. Porto Alegre: Livraria do Advogado, 2004, p. 347.

${ }^{8}$ LÔBO, Paulo Luiz Netto. Entidades Familiares Constitucionalizadas: para além do numerus clausus. Disponível em: <http://www.egov.ufsc.br/portal/sites/default/files/anexos/9408-9407-1PB.pdf>. Acesso em 09 set. 2015.
} 
A afetividade também está intrínseca no art. 1.566 do Código Civil ${ }^{9}$, o qual prevê que os filhos menores sujeitam-se ao poder familiar, ficando então, os pais submetidos ao dever de sustentá-los e tê-los sob sua guarda e de educá-los.

Na palavras de CARLOS ROBERTO GONÇALVES, o dever de dirigir a criação e educação aos filhos se mostra como o mais importante de todos, já que se revela como o mais relevante para a construção do caráter do indivíduo:

O dever de dirigir a criação e educação dos filhos menores é o mais importante de todos. Incumbe aos pais velar não só pelo sustento dos filhos, como pela sua formação, a fim de torná-los úteis a si, à família e à sociedade. O encargo envolve, pois, além do zelo material, para que o filho fisicamente sobreviva, também o moral, para que, por meio da educação, forma seu espírito e seu caráter $^{10}$.

Fato é que o dever de dirigir a criação e educação pressupõe a assistência moral e que essa última envolve o afeto. Difícil acreditar que exista alguém que crie uma criança com toda atenção que lhe é devida e preste a merecida assistência moral sem o afeto, por pura e mera obrigação legal.

Como consequência da ausência de assistência moral e o devido cumprimento dos deveres legais da paternidade, o STJ, em recente decisão, entendeu por reconhecer o direito requerido pelo filho abandonado de suprimir o seu sobrenome paterno e incluir o sobrenome de sua avó materna. É possível perceber através da ementa doacórdão do REsp n ${ }^{\circ}$ 1.304.718/SP:

RECURSO ESPECIAL. DIREITO CIVIL. REGISTRO CIVIL. NOME. ALTERAÇÃO. SUPRESSÃO DO PATRONÍMICO PATERNO. ABANDONO PELO PAI NA INFÂNCIA. JUSTO MOTIVO. RETIFICAÇÃO DO ASSENTO DE NASCIMENTO. INTERPRETAÇÃO DOS ARTIGOS 56 E 57 DA LEI No 6.015/73. PRECEDENTES.

1. O princípio da imutabilidade do nome não é absoluto no sistema jurídico brasileiro. $\square$

\footnotetext{
${ }^{9}$ Art. 1.566. São deveres de ambos os cônjuges:

(...)

IV - sustento, guarda e educação dos filhos;

${ }^{10}$ GONÇALVES, Carlos Roberto. Direito Civil Brasileiro - Direito de Família. Vol. 6. $12^{\text {a }}$ Ed. Rio de Janeiro: Saraiva. 2015, p. 418.
} 
2. O nome civil, conforme as regras dos artigos 56 e 57 da Lei de Registros Públicos, pode ser alterado no primeiro ano após atingida a maioridade, desde que não prejudique os apelidos de família, ou, ultrapassado esse prazo, por justo motivo, mediante apreciação judicial e após ouvido o Ministério Público.

3. Caso concreto no qual se identifica justo motivo no pleito do recorrente de supressão do patronímico paterno do seu nome, pois, abandonado pelo pai desde tenra idade, foi criado exclusivamente pela mãe e pela avó materna.

4. Precedentes específicos do STJ, inclusive da Corte Especial. $\square$ 5. RECURSO ESPECIAL PROVIDO [Grifou-se] ${ }^{11}$

O pleito em questão foi formulado no bojo de uma ação de retificação de registro público, fundamentando o pedido no fato de o recorrente ter sido criado exclusivamente pela mãe e pela avó materna, na medida em que o genitor o abandonou desde tenra idade, de modo que não desenvolveu com este qualquer vínculo afetivo.

A parte teve de recorrer ao STJ após ter o Tribunal de São Paulo mantido a decisão do Juízo da Sétima Vara Cível de Campinas - SP que acolhera parcialmente a pretensão do autor, apenas para autorizar a inclusão dos patronímicos da avó materna no seu assento de nascimento, preservando-se, contudo, o sobrenome paterno.

Como fundamento para o provimento do REsp, o ministro relator Tarso Sanseverino afirma que o recorrente não desenvolveu qualquer laço de afetividade com seu genitor e não há qualquer razão para a manutenção de seu sobrenome. Como se observa:

Com efeito, conforme se extrai da sentença (fls. 40/43), após o divórcio dos pais do recorrente, ocorrido quando contava este com tenra idade, seu pai afastou-se completamente da família, de modo que passou a infância, adolescência e juventude exclusivamente sob os cuidados de sua mãe e, especialmente, de sua avó materna, por quem nutre sentimentos de amor, carinho, amizade e respeito.

Não desenvolveu, assim, qualquer laço afetivo com a figura do pai, que, conforme afirmou, "teve mero enredo biológico em sua vida". [Grifou-se] ${ }^{12}$

O Ministro prossegue em seu voto dizendo que "o nome é elemento da personalidade, identificador e individualizador da pessoa na sociedade e no âmbito familiar, resta caracterizado o justo motivo do recorrente, nos

\footnotetext{
${ }^{11}$ STJ, $3^{\text {a }}$ Turma, Resp. 1.304.718 - SP (2011/0304875-5), Rel. Min. Paulo de Tarso Sanseverino. 18 dez. 2014. Disponível em <www.stj.jus.br>. Acesso em 03 set. 2015.

${ }^{12}$ Ibid.
} 
moldes preconizados por essa Corte"13.

Afirma, ainda, que existe o direito do sujeito de portar um nome que não lhe remeta à quaisquer angústias, sobretudo decorrente do abandono paterno do caso concreto, conforme se observa:

Ademais, o direito da pessoa de portar um nome que não lhe remeta às angústias decorrentes do abandono paterno e, especialmente, corresponda à sua realidade familiar, parece-me sobrepor ao interesse público de imutabilidade do nome, já excepcionado pela própria Lei de Registros Públicos. [Grifou-se] ${ }^{14}$.

Assim, ainda que sejam infinitas as tentativas de alguns pais de se absterem de cumprir com seus deveres perante os filhos, tal responsabilidade encontra-se inscrita no ordenamento jurídico, e seu descumprimento gera responsabilidades, tornando tal conduta passível de indenização ao menor lesado, bem como a diversas outras restrições e implicações, até mesmo no nome da pessoa.

\subsubsection{Princípio da Afetividade como Direito Fundamental da Personalidade}

A Constituição de 1988 prevê, em seu artigo $1^{\circ}$, inciso III, o princípio da dignidade da pessoa humana. Tal princípio, estruturante de todo nosso ordenamento jurídico, não pode ser interpretado de forma vazia e banal como vem sendo constantemente realizado.

A afetividade efetivamente não é tratada de forma categórica como princípio pela nossa legislação positivada, porém está implícito no ordenamento jurídico pátrio, devendo ser considerado como um princípio do Direito de Família.

A afetividade se define como a relação de carinho ou cuidado que se tem com alguém íntimo ou querido, sendo o estado psicológico que permite a

\footnotetext{
${ }^{13}$ Ibid.

${ }^{14}$ Ibid.
} 
demonstração e existência de sentimentos e emoções a outro ser vivo ${ }^{15}$.

Assim, como uma das vertentes do princípio da dignidade da pessoa humana, encontramos o princípio da afetividade, passando a família a encontrar fundamento no afeto, na ética, e no respeito entre seus membros.

Atualmente, se tem o conhecimento da família como um instrumento de proteção da pessoa humana. Em sua origem, a família tinha uma conotação patrimonial, referindo à propriedade de escravos de certo alguém.

Com o passar do tempo, entretanto, tal conotação patrimonial deixou de ser coerente e a família passou a ser vista a partir de diversos valores, passando a exercer diferentes funções. NELSON ROSENVALD e CRISTIANO CHAVES DE FARIAS, trazem o conceito atual de família, demonstrando a sua importância para o desenvolvimento da pessoa humana:

Com o passar dos tempos, porém, o conceito de família mudou significativamente até que, nos dias de hoje, assume uma concepção múltipla, plural, podendo dizer respeito a um ou mais indivíduos, ligados por traços biológicos ou sócio-psicoafetivos, com intenção de estabelecer, eticamente, o desenvolvimento da personalidade de cada um ${ }^{16}$.

Dessa forma, a família é hoje baseada no afeto e encarada como um instrumento para a proteção e desenvolvimento do indivíduo, capaz de concretizar o princípio da dignidade da pessoa humana. Não por outro motivo, pois, o principio da afetividade deve ser encarado como decorrência daquele.

Além de ser uma vertente do macroprincípio da dignidade humana, o princípio da afetividade pode ser encontrado através da leitura não apenas da Constituição Federal e do Código Civil, mas de leis esparsas.

\footnotetext{
${ }^{15}$ VESENTINI, CÍNTIA. Responsabilidade parental: abandono afetivo. Disponível em $<$ http://www.juridicohightech.com.br/2014/04/responsabilidade-parental-abandono.html>. Acesso em 28 set. 2015

${ }^{16}$ FARIAS, C. C; ROSENVALD, N. Direito das Famílias. 2 ed. Rio de Janeiro:Lumen Juris, 2010, p.9.
} 
Dentro das diversas leis esparsas que versam sobre o Direito de Família, encontra-se a Lei Maria da Penha (2006), a Lei da Guarda Compartilhada (2008), a Lei da Adoção (2009) e a Lei da Alienação Parental (2010).

Todas essas leis tratam da afetividade como um conceito jurídico, que será melhor explanado no item 1.2 que trata da jurisdicização do afeto no presente trabalho.

Nesse ponto da afetividade, PAULO LÔBO firma o entendimento de que a afetividade não se resume apenas como um conjunto de fenômenos ou de sentimentos, mas como princípio constitucional, nos seguintes termos:

A afetividade é construção cultural, que se dá na convivência, sem interesses materiais, que apenas secundariamente emergem quando ela se extingue. Revelase em ambiente de solidariedade e responsabilidade. Como todo princípio, ostenta fraca densidade semântica, que se determina pela mediação concretizadora do intérprete, ante cada situação real. Pode ser assim traduzido: onde houver uma relação ou comunidade unidas por laços de afetividade, sendo estes suas causas originária e final, haverá família ${ }^{17}$.

O referido Autor, ao defender a afetividade como princípio constitucional, afirma que:

o principio da afetividade tem fundamento constitucional; não é petição de princípio, nem fato exclusivamente sociológico ou psicológico. No que respeita aos filhos, a evolução dos valores da civilização ocidental levou à progressiva superação dos fatores de discriminação entre eles. Projetou-se, no campo jurídico-constitucional, a afirmação da natureza da família como grupo social fundado essencialmente nos laços de afetividade. ${ }^{18}$

Por ser a afetividade um princípio constitucional, derivado do princípio da dignidade da pessoa humana, o afeto passa a ser um dever previsto pelo ordenamento jurídico e o seu descumprimento acarreta no dever secundário de reparação.

\footnotetext{
${ }^{17}$ LÔBO, Paulo Luiz Netto. Entidades Familiares Constitucionalizadas: para além do numerus clausus. Disponível em: <http://www.egov.ufsc.br/portal/sites/default/files/anexos/9408-9407-1PB.pdf> Acesso em 11 set. 2015.

${ }^{18}$ LÔBO, Paulo Luiz Netto. Principio Jurídico da Afetividade na Filiação. In: Jus Navigandi. Terezina. Ano 5, no 41, Maio 2000. Disponível em: <http://jus.com.br/artigos/527>. Acesso em: 09 set. 2015.
} 
A afetividade tem desenhado um papel de extremo destaque no cenário do Direito de Família. Os efeitos culturais da filiação por afeto que desenvolvem na famílias da atualidade não podem ser menosprezados. Muitas vezes, os efeitos culturais da filiação afetiva superam os efeitos da filiação por consanguinidade.

O parentesco socioafetivo abrange os famosos filhos de criação e é inserido são os na expressão "outra origem" do artigo 1.593, do Código Civil de $2002^{19}$.

Dessa forma, pode se dizer que a afetividade passou a ser um dever, isto é, um imperativo da relação familiar. A ideia de afeto está ligada intimamente a ideia de família e se desdobra no companheirismo, na atenção, na solidariedade, no cuidado recíproco e, sobretudo, no respeito mútuo entre os membros da família.

Para MARIA BERENICE DIAS:

\begin{abstract}
A doutrina e a jurisprudência têm reconhecido inúmeros princípios constitucionais implícitos, cabendo destacar que inexiste hierarquia entre os princípios constitucionais explícitos ou implícitos. É difícil quantificar ou tentar nominar todos os princípios que norteiam o direito das famílias. Alguns não estão escritos nos textos legais, mas têm fundamentação ética no espírito dos ordenamentos jurídicos para possibilitar a vida em sociedade.

(...)Há princípios especiais que são próprios das relações familiares e devem sempre servir de norte na hora de se apreciar qualquer relação que envolva questões de família, despontando entre eles os princípios da solidariedade e da afetividade. ${ }^{20}$
\end{abstract}

Essa afetividade traduz-se no necessário e imprescindível respeito às peculiaridades individuais de cada um dos membros da família, preservando a dignidade de todos os seus componentes. Para NELSON ROSENVALD e CRISTIANO CHAVES DE FARIAS “(...) a família é o refúgio das garantias fundamentais reconhecidas a cada um dos cidadãos" $" 21$.

\footnotetext{
${ }^{19}$ Art. 1.593. O parentesco é natural ou civil, conforme resulte da consanguinidade ou outra origem.

${ }^{20}$ DIAS. Maria Berenice. Manual de Direito das Famílias. $8^{a}$ Edição. Revista, atualizada e ampliada. São Paulo: Editora Revista dos Tribunais, 2011, p. 61.

${ }^{21}$ FARIAS, C. C; ROSENVALD, N. Direito das Famílias. 2 ed. Rio de Janeiro: Lumen Juris, 2010, p.9.
} 
Por essas razões, como já explicitado, o princípio da afetividade tem fundamento constitucional e não é fato exclusivo da sociologia ou da psicologia.

Para PAULO LÔBO ${ }^{22}$, existem quatro fundamentos constitucionais que cerceiam o princípio da afetividade: (i) a igualdade entre os filhos, independentemente da origem ${ }^{23}$; (ii) a adoção, como escolha afetiva igualando direitos ${ }^{24}$; (iii) a instituição familiar formada por qualquer dos genitores junto de seus descendentes, adotivos o não ${ }^{25}$ e (iv) o direito à convivência familiar como prioridade absoluta da criança e do adolescente. $^{26}$

Como já mencionado, o referido princípio está implícito na Constituição Federal como decorrência do princípio da dignidade da pessoa humana, bem como por ter Carta Magna reconhecido a união estável como entidade familiar merecedora de tutela jurídica, e ter a palavra "afeto" adquirido reconhecimento e inserção no sistema jurídico, mesmo não expressamente prevista no texto constitucional.

No que diz respeito aos filhos, a civilização ocidental, ao implantar sua cultura nas diversas famílias mundiais, resultou em um cenário de superação dos fatores de discriminação, firmando, no campo jurídicoconstitucional, a natureza da família como grupo social fundado essencialmente nos laços de afetividade.

Através da simples leitura do rol de direitos individuais e sociais elencados na Constituição Federal de 1988, em seu Título II - Direitos Fundamentais, se verifica que os dispositivos constitucionais asseguram o afeto, sendo o Estado o primeiro obrigado a garantir condições para que tais direitos sejam efetivamente implementados e assegurados a todos.

O dever estatal se dá através de atribuições ou proibições estabelecidas nos dispositivos do ordenamento jurídico, como a proibição

\footnotetext{
${ }^{22}$ LÔBO, Paulo Luiz Netto. Código Civil comentado. São Paulo: Atlas, 2003, p.42-43

${ }^{23}$ Artigo $227, \S 6^{\circ}$ da CRFB

${ }^{24}$ Artigo $227, \S \S 5^{\circ}$ e $6^{\circ}$ da CRFB

${ }^{25}$ Artigo $227, \S 4^{\circ}$ da CRFB

${ }^{26}$ Artigo, 227, caput da CRFB
} 
ou a interferência de qualquer pessoa na comunhão do casal, cabendo somente ao homem e a mulher decidirem pelo planejamento familiar.

Nesse sentido, enxergar a afetividade como princípio do ordenamento jurídico pátrio se mostra como uma consequência lógica decorrente da interpretação constitucional. Assim, cabe ao Estado e à sociedade a tutela do direito dos membros das famílias à convivência familiar afetiva.

TÂNIA PEREIRA afirmaque a conivência familiar se consolidou na doutrina e na jurisprudência como um direito fundamental, projetando os vínculos de afetividade no campo jurídico:

Reconhecida a Convivência Familiar como um Direito Fundamental, consolidouse em nossa Doutrina e Jurisprudência a não discriminação de filhos e a corresponsabilidade dos pais quanto ao exercício do poder familiar (...) os vínculos de afetividade projetam-se no campo jurídico como a essência das relações familiares. $^{27}$

O Tribunal de Justiça de Sergipe, com o intuito de comprovar a aplicação do princípio da afetividade como fator decisivo, independente do vínculo sanguíneo, decidiu favorável ao pedido de concessão de adoção de criança que vive com casal adotante desde os seis meses de vida:

APELAÇAO CÍVEL. AÇAO DE ADOÇAO PROPOSTA POR QUEM DETÉM A GUARDA DE FATO DO MENOR DESDE OS SEIS MESES DE VIDA. INEXISTÊNCIA DE INSCRIÇAO PRÉVIA NO CADASTRO OFICIAL DE ADOÇAO NAO CONSTITUI CONDIÇAO SINE QUA NON PARA O DEFERIMENTO DA MEDIDA. FORMALISMO LEGAL QUE NAO PODE SOBREPUJAR AOS INTERESSES DO MENOR. PRECEDENTES JURISPRUDENCIAIS. MELHOR INTERESSE DO INFANTE. LAÇOS DE AFETIVIDADE ESTABELECIDOS COM OS PRETENSOS ADOTANTES. PREVALÊNCIA DOS ART. 43 DA LEI 8.069 /90 E ART. 1.625 , DO CÓDIGO CIVIL . SENTENÇA REFORMADA. RECURSO CONHECIDO E PROVIDO (Grifou-se) ${ }^{28}$.

\footnotetext{
${ }^{27}$ PEREIRA, Tânia da Silva. O Cuidado como Valor Jurídico. In: A ética da convivência familiar: sua efetividade no quotidiano dos Tribunais. Tânia da Silva Pereira e Rodrigo da Cunha Pereira (coords.). Rio de Janeiro: Forense, 2006, p. 34.

${ }^{28}$ TJSE, Apelação Cível n. 2012207781, Relatora: Suzana Maria Carvalho Oliveira. j 04 jun. 2012, $1^{\text {a }}$ Câmara Cível, Data de Publicação: 04/06/2012. Disponível em: <http://tjse.jusbrasil.com.br/jurisprudencia/21863753/apelacao-civel-ac-2012207781-se-tjse>. Acesso em: 09 set. 2015.
} 
MARIA BERENICE DIAS observa que um dos principais princípios norteadores do Direito das Família é o princípio da afetividade e com a finalidade de promover o bem-estar de todos os membros da família, o afeto passa a ser considerado como um direito da personalidade. Para a autora, o afeto é um verdadeiro direito fundamental, permitindo, por exemplo, o reconhecimento da igualdade entre a filiação biológica e a socioafetiva.

Conclui-se, assim, que o princípio da afetividade especializa, no campo do direito das famílias, o macroprincípio da dignidade da pessoa humana, positivado no art. $1^{\circ}$, inciso III da CRFB, princípios esses que permeiam todas as relações jurídicas e submetem integralmente o ordenamento jurídico nacional.

\subsubsection{Princípio da Paternidade Responsável como Obrigação Legal da Família}

A Constituição de 1988, ao tratar da família em seu artigo 226, a trata como sendo base da sociedade. A Carta Constitucional determina a igualdade entre o homem e a mulher no que toca os direitos e deveres referentes à sociedade conjugal. Além disso, o mesmo dispositivo, em seu parágrafo $7^{\circ}$, diz que a família é fundada nos princípios da dignidade da pessoa humana e da paternidade responsável.

O princípio da paternidade responsável significa responsabilidade e esta começa na concepção e se estende até que seja necessário e justificável para o cumprimento de todos os deveres enunciados no artigo 227, quais sejam: o direito à vida, à saúde, à alimentação, à educação, ao lazer, à profissionalização, à cultura, à dignidade, ao respeito, à liberdade e à convivência familiar e comunitária, além de colocá-los a salvo de toda forma de negligência, discriminação, exploração, violência, crueldade e opressão.

Além de expressamente previsto na Carta Magna, a Convenção sobre os Direitos da Criança, de 1989, ratificada pelo Brasil em 24 de setembro de 
1990, dispõe que toda criança terá direito de conhecer seus pais e ser amparada e cuidada por eles. Além disso, foi incluído no art. 27, da Lei ${ }^{\circ}$ 8.069/90 (Estatuto da Criança e do Adolescente) que o reconhecimento do estado de filiação é direito personalíssimo, indisponível e imprescritível, podendo ser exercitado contra os pais ou seus herdeiros, sem qualquer restrição, sendo sempre observado o segredo de justiça então inerente.

A partir da Constituição de 1988 e dessas mudanças normativas, o direito da criança ou do adolescente ao reconhecimento do seu estado de filho passa a ser absoluto, podendo ser exercido a qualquer tempo e, inclusive, em face dos herdeiros dos pais, considerando-se de natureza personalíssima e impassível de disposição.

Cabe ressaltar que anteriormente a Constituição Federal, tal direito não era absoluto, sendo impedido em algumas situações pelo Código Civil de 1916, como no caso de filhos ilegítimos adulterinos e incestuosos.

Como meio garantidor de maior efetividade ao exercício do direito de filiação, bem como maior obrigatoriedade ao princípio da paternidade responsável, a Lei $\mathrm{n}^{\circ} 8.560$ prevê que o reconhecimento dos filhos é irrevogável e indica os meios e as formas de reconhecimento.

Sendo assim, é possível extrair da ratio constitucional uma opção pela responsabilidade familiar como sendo um princípio norteador das relações familiares.

A importância dos pais na formação dos filhos é algo notório e que pesquisas elaboradas por profissionais da área da psicologia demonstram constantemente. Importante é que os pais estejam envolvidos no processo de criar e educar os filhos de forma saudável. Sempre se soube que tal tarefa se mostra difícil,porém desde meados do século XX a estrutura familiar passa por grandes transformações modificando essa relação parental.

A mulher passou a ser peça fundamental no mercado de trabalho, reivindicando direitos de igualdade com o homem, requerendo $\mathrm{e}$ necessitando da participação mais efetiva do pai. Além disso, o índice de 
separações conjugais apenas aumentou o que acaba, infelizmente, por apartar pais de seus filhos e, muitas vezes, a prole é gerada e educada em meio a fortes conflitos entre os seus responsáveis.

Nessa esteira, o princípio da paternidade responsável deve ser encarado como um dever legal, previsto não apenas na Constituição Federal, mas como em diversas lei esparsas. Tal princípio tem por objetivo o planejamento familiar racional e independente, a fim de que os seus membros possam se desenvolver de forma natural e integral.

\subsubsection{Dos Maus Tratos à Ausência de Trato}

Apesar de, a princípio, o abandono afetivo não parecer fornecer o mesmo risco de vida a que os maus tratos e o descarte físico submetem a criança ou o adolescente, há diversas implicações no psiquismo do indivíduo que podem acarretar consequências muito mais graves à formação do ser humano. Por isso, muitas vezes o castigo físico que parece tão maldoso e repudiado se mostra como algo pequeno diante do castigo que é submetido aquele que é vitima do abandono afetivo.

Desse modo, propõe-se uma noção abrangente de mau trato infantojuvenil, nela se incluindo não só as formas de violência direta contra a integridade física e psíquica da criança, como ainda as formas de privação, omissão ou negligência material e afetiva que comprometem o seu crescimento e desenvolvimento

Ainda que o sustento material esteja presente, a ausência afetiva simboliza o desinteresse, a falta de desejo e remete, ao final, o desamparo. Assim, ao decorrer do tempo,torna-se inatingível o desejo de convivência entre pai e filho.

Importante salientar mais uma vez que o vínculo afetivo nem sempre está presente nas relações consanguíneas. Atualmente, é crescente o interesse afetivo nas novas composições familiares. São crescentes os casos de filiação socioafetiva em famílias compostas por pessoas, casadas ou não, 
que convivem com filhos do outro parceiro ou de parentes próximos, assumindo de forma integral os cuidados parentais, materiais e afetivos.

Outras situações como a adoção por casais homoafetivos possibilitaram uma reviravolta no tema, bem como uma radical mudança na postura do Poder Judiciário, já que se tornou possível o acolhimento de uma criança simplesmente com base no afeto.

Um artigo científico intitulado por "Os maus tratos à criança na família”, que foi realizado, entre 1995 e 1999, no Instituto de Ciências Sociais (Universidade de Lisboa), por Ena Nunes de Almeida, Isabel Margarida André e Ana Nunes de Almeida, teve como objetivo o estudoda situação dos maus tratos às crianças na família em Portugal. Nesse estudo, se chegou a seguinte conclusão:

\begin{abstract}
As modalidades de mau trato - Encontraram-se na amostra 25 modalidades de mau trato, recobrindo uma vasta diversidade de abusos - físicos e psíquicos - e negligências -materiais e afectivas. Cada criança é vítima de uma ou mais destas modalidades.

Sequelas físicas- Sete crianças morreram na sequência do mau trato de que foram vítimas; $23 \%$ ficou com sequelas físicas (na Madeira esse valor ascende mesmo a 42\%, no Norte Litoral a 34\%), 9\% com sequelas neurológicas. Cerca de $50 \%$ das crianças foi descrita como tendo sequelas psicológicas a longo termo na sequência do mau trato.

O relator do mau trato - $25 \%$ dos casos foram os familiares e vizinhos; em $21 \%$ dos casos o relator foi o pai ou a mãe; os vários profissionais da infância contribuem com $37 \%$ dos casos; a própria criança só muito raramente $(6 \%)$ denuncia o mau trato de que é vítima. Em 54\% casos houve o recurso subsequente a serviços médicos, sendo essa percentagem mais elevada na AML (71\%), Madeira e Centro Interior e Litoral (62\%).

$\mathrm{O}$ agressor - Os resultados mostram que o/a agressor/ a é na esmagadora maioria das situações um dos adultos responsáveis por ela, anteriormente caracterizado. Em $83 \%$ casos co-reside com a criança, em $24 \%$ das situações é apenas a mãe a agressora, em $23 \%$ casos os dois pais, em $21 \%$ o pai; $13 \%$ dos agressores são toxicodependentes, mas $45 \%$ são alcoólicos; na Madeira (67\%), Açores (63\%), e Norte Interior (62\%) esta percentagem é ainda mais elevadas; $10 \%$ dos agressores cometeram actos considerados como crime, sendo esta percentagem mais alta na Madeira, Açores, e Oeste Ribatejo. ${ }^{29}$
\end{abstract}

Por essa razão, o envolvimento afetivo se tornou um pilar na construção das famílias atuais, colaborando para a importância da

\footnotetext{
${ }^{29}$ ALMEIDA, Ena Nunes de, et al.. Os maus tratos às crianças na família. Acta Médica Portuguesa, Lisboa, $n^{\circ} 15$, p. 257-267, 2002.
} 
afetividade nas relações familiares. Assim, conforme será amplamente discutido, a ausência de afetividade é capaz de trazer consequências ainda mais serias que a violência ativa contra a integridade física do filho, gerando marcas eternas e indissolúveis na formação e no caráter da vítima.

\subsection{A Jurisdicização do Afeto}

A valorização do afeto se mostrou como um processo natural com o decorrer das modificações das estruturas familiares. O reconhecimento jurídico do afeto dentro do Direito e da lei decorre de uma análise histórica e sistemática, sendo consequência de um conjunto de transformações na sociedade.

Dessa forma, diante das mudanças sociais, o direito também teve de ser alterado, permitindo que fosse dada primazia à realidades outrora subjugadas ao disposto no então vigente texto legal.

Como um exemplo claro de valorização do afeto, traz-se a filiação socioafetiva, através da qual se mostrou possível enxergar que pai é aquele que educa, que ama, que contribui na formação da personalidade de seu filho.

Hoje, tem-se mais claro que a filiação não é somente oriunda no laço de sangue. Ao lado desse, desponta a importância do laço que surge entre pai e filho em momento posterior ao da concepção biológica, sendo relevante o laço construído pela convivência, pelo respeito e pelo amor mútuo.

Nessa esteira atual da valorização do afeto, a afetividade pode ser encarada como um conceito jurídico, cuja carga valorativa pressupõe direitos e deveres, assim como qualquer conceito concreto juridicamente tratado.

A jurisdicização do afeto nada mais é do que concretizar e fornecer valor jurídico a algo inerentemente abstrato e subjetivo: o afeto. $\mathrm{O}$ afeto, até há poucos anos era apenas um sentimento e que jamais poderia ser exigido 
pelo Estado através das leis.

O cenário foi sendo modificado e a sociedade passou a requerer a tutela sobre o afeto. Desse modo, como já explicitado no item 1.1.2do presente trabalho, a afetividade se tornou um princípio decorrente da interpretação normativa e que passa a ser considerado como um direito da personalidade.

MARIA BERENICE, sobre o tema esclarece que:

O novo olhar sobre a sexualidade valorizou os vínculos conjugais que passaram a se sustentar no amor e no afeto. Na esteira dessa evolução, o direito de família instalou uma nova ordem jurídica para a família, atribuindo valor jurídico ao afeto. $^{30}$

Desse modo, diante da alteração na sociedade, nada mais óbvio do que o Poder Legislativo alterar a legislação para fornecer a tutela pretendida.

Nessa esteira, algumas alterações legislativas processadas nos últimos anos passaram a fazer referência expressa ao afeto e à afetividade, o que demonstra um certo avanço de técnica legislativa e indica certa sensibilidade e uma clara tendência. Isso pode ser percebido em na chamada Lei Maria da Penha (2006), na Lei da Guarda Compartilhada (2008), na nova Lei da Adoção (2009) e na Lei da Alienação Parental (2010).

A Lei Maria da Penha (Lei Federal $n^{\circ}$ 11.340/2006) traz uma interessante definição sobre o conceito de família, ao estipular quais relações estariam abrangidas pelas suas disposições legais. Além disso, estabelece que quaisquer relações íntimas de afeto também são atingidas por suas disposições. Estas conceituações estão previstas no art. $5^{\circ}$, incisos II e III do referido texto legal.

Lei 11.340/2006 - Lei Maria da Penha

Art. $5^{\mathrm{o}}$ Para os efeitos desta Lei, configura violência doméstica e familiar contra a mulher qualquer ação ou omissão baseada no gênero que lhe cause morte, lesão,

\footnotetext{
${ }^{30}$ DIAS, Maria Berenice. Manual de Direito das Famílias. $8^{\mathrm{a}}$ Edição. Revista, atualizada e ampliada. São Paulo: Editora Revista dos Tribunais, 2011, p. 68.
} 
sofrimento físico, sexual ou psicológico e dano moral ou patrimonial:

I - no âmbito da unidade doméstica, compreendida como o espaço de convívio permanente de pessoas, com ou sem vínculo familiar, inclusive as esporadicamente agregadas;

II - no âmbito da família, compreendida como a comunidade formada por indivíduos que são ou se consideram aparentados, unidos por laços naturais, por afinidade ou por vontade expressa;

III - em qualquer relação íntima de afeto, na qual o agressor conviva ou tenha convivido com a ofendida, independentemente de coabitação.

Parágrafo único. As relações pessoais enunciadas neste artigo independem de orientação sexual. [Grifou-se] ${ }^{31}$

RICARDO LUCAS CALDERÓN, em sua obra Princípio da Afetividade no Direito de Família, ao discorrer sobre o afeto previsto pela Lei Maria da Penha, diz que:

É possível perceber a referência expressa ao afeto na caracterização das relações
que estariam cobertas pela referida lei. Como o objetivo expresso é abarcar
situações de violência familiar, no inc. III engloba todos os casos que envolvem
"relação íntima de afeto", ou seja, recorre ao afeto para qualificar os
relacionamentos que quer proteger. Percebe-se também que no inc. II o legislador
previu um conceito elastecido de família ao incluir nele toda comunidade
formada por indivíduos unidos por vontade expressa, no que se correlaciona
indiretamente a um vínculo afetivo (que estaria englobado nessa vontade expressa
de viver em família). A abertura conferida por tal definição de família já que não
traz os problemas de muitas outras conceituações restritas ou precipuamente
formais. Digna de elogio, também, o alerta que a lei se aplica independentemente
de orientação sexual. ${ }^{32}$

A Lei da Guarda Compartilhada (Lei Federal n 11.698/2008), por sua vez, alterou dois dispositivos do Código Civil, quais sejam, os artigos 1.583 e 1.584 . Em ambos os artigos há a remissão ao afeto (art. 1.583, § $2^{\circ}$ I) e à afetividade (art. $1.584, \S 5^{\circ}$ ). A função que a afetividade exerce na definiçãa de guarda se constitui como um critério decisivo na escolha do guardião. Assim, a afetividade deve ser apurada no caso concreto a fim de que o julgador tenha subsídios para definir eventual conflito envolvendo a guarda do filho.

A Lei da Adoção (Lei Federal no 12.010/2009) também menciona expressamente a afetividade quando prevê as condições necessárias para a

\footnotetext{
${ }^{31}$ Lei $\quad \mathrm{n}^{\mathrm{o}} \quad 11.340 / 2006$. Disponível em <http://www.planalto.gov.br/ccivil_03/_ato20042006/2006/lei/l11340.htm>. Acesso em 23 set. 2015.

${ }^{32}$ CALDERÓN, Ricardo Lucas. Princípio da afetividade no direito de família. Rio de Janeiro: Renovar, 2013. 257-258 p.
} 
estipulação da família extensa ou substituta, passando a afetividade ser um critério balizador do julgador no momento de definir o destino do adotando.

Lei 12.010/2009 - Lei da Adoção

Art. 25. Entende-se por família natural a comunidade formada pelos pais ou qualquer deles e seus descendentes.

Parágrafo único. Entende-se por família extensa ou ampliada aquela que se estende para além da unidade pais e filhos ou da unidade do casal, formada por parentes próximos com os quais a criança ou o adolescente convive e mantém vínculos de afinidade e afetividade.

Art. 28.

$\S 1^{\circ}$ Sempre que possível, a criança ou o adolescente será previamente ouvido por equipe interprofissional, respeitado seu estágio de desenvolvimento e grau de compreensão sobre as implicações da medida, e terá sua opinião devidamente considerada.

$\S 2^{\circ}$ Tratando-se de maior de 12 (doze) anos de idade, será necessário seu consentimento, colhido em audiência.

$\S 3^{\circ} \mathrm{Na}$ apreciação do pedido levar-se-á em conta o grau de parentesco e a relação de afinidade ou de afetividade, a fim de evitar ou minorar as consequências decorrentes da medida.

$\S 4^{\circ}$ Os grupos de irmãos serão colocados sob adoção, tutela ou guarda da mesma família substituta, ressalvada a comprovada existência de risco de abuso ou outra situação que justifique plenamente a excepcionalidade de solução diversa, procurando-se, em qualquer caso, evitar o rompimento definitivo dos vínculos fraternais. [Grifou-se] $]^{33}$

Sabe-se que no processo de adoção, a definição de família extensa ou substituta eleita caracteriza-se como um momento crucial, sendo que para tal contexto, o legislador entendeu por bem incluir a afetividade como um dos critério que orientarão no momento da decisão do juízo, juntamente com o demais critérios previstos pela própria lei, atendendo sempre ao melhor interesse da criança e do adolescente.

A lei , portanto, faz clara indicação no sentido de que a afetividade será fato relevante e decisivo a ser levado em conta no processo de adoção.

Sabe-se que, inicialmente, a adoção era realizada com o objetivo principal de perpetuação do culto doméstico. Não havia a discussão do que seria melhor para a criança ou adolescente adotado, importando somente o interesse do adotando. Inexistia preocupação com a constituição do vínculo de afinidade e afetividade entre adotante e adotado.

No Brasil, o Código Civil de 1916, nos artigos 368 a 378, foi

\footnotetext{
${ }^{33}$ Lei $\quad \mathrm{n}^{\mathrm{o}} \quad 12.010 / 2009$. Disponível em <http://www.planalto.gov.br/ccivil_03/_ato20072010/2009/lei/l12010.htm>. Acesso 25 set. 2015.
} 
primeira legislação a trazer o instituto da adoção. Tal positivação legislativa, porém, não cuidou da matéria com necessária relevância e profundidade.

Sabe-se que, à época do referido diploma, somente maiores de 50 anos, sem prole legítima ou legitimada é que poderiam adotar, sendo necessária a diferença de idade entre adotante e adotado ser de, pelo menos, 18 anos. O pátrio poder dos pais biológicos era transferido para os novos pais adotivos, mas os direitos e deveres que resultavam do parentesco natural não se extinguiam.

Assim, a adoção tinha caráter meramente contratual, pois se caracterizava como um negócio jurídico bilateral e solene, prevendo a possibilidade de rompimento do vínculo por acordo de vontade.

\begin{abstract}
A par disso, nota-se que neste código a adoção tinha caráter contratual, pois se tratava de negócio jurídico bilateral e solene, sendo possível ainda a dissolução do vínculo, pelo acordo de vontade, se as partes fossem maiores. Percebe-se que aqui o instituto da adoção visava apenas à pessoa do adotante, ficando o adotando em segundo plano, aspecto esse que não se admite na adoção moderna. ${ }^{34}$
\end{abstract}

Diante de tal cenário, e a necessidade de alteração legislativa, surge o Código Civil de 2002, diploma o qual modificou a finalidade da adoção, passando a dar maior relevância aos interesses do adotado.

Esta alteração ocorreu em decorrência da promulgação da Constituição Federal de 1988, que em seu artigo 227, § $6^{\circ}$ prevê a igualdade dos filhos, determinando que os filhos, havidos ou não da relação do casamento, ou por adoção, terão os mesmos direitos e qualificações, proibidas quaisquer designações discriminatórias relativas à filiação, mandamento este que foi ratificado pelo art. 20 do ECA.

Assim, após o Código Civil de 2002, foi promulgada a lei específica da adoção, na qual ratifica a transferência da importância dos interesses do adotante para os interesses do adotado, propondo destaque à afetividade.

\footnotetext{
${ }^{34}$ SILVA, N. S.; BATISTA, J. P. A Constituição Do Vínculo Na Adoção - Aspectos Jurídicos e Afetivos. Disponível em $<$ http://Ienomat.Com.Br/Revista/Index.Php/Judicare/Article/View/56/171>. Acesso em 25 set. 2015
} 
Sobre o tema,LUCAS CALDERÓN destaca, brilhantemente, a importância que os textos legais conferem ao afeto, o tornando como critério singular e relevante no momento do julgamento de um caso concreto:

\begin{abstract}
O que merece ser destacado tanto na Lei $n^{\circ} 12.010 / 09$ como na Lei $n^{\circ} 11.698 / 08$ é a inclusão da afetividade como critério decisório direcionado ao julgador no momento do acertamento de um caso concreto específico. Ou seja, tais disposições não trazem afetividade apenas de maneira genérica, retórica ou de algum modo programática, muito pelo contrário, as reformas legislativas a incluíram como critério a ser concretamente observado na solução do caso $s o b$ judice. Nesses textos, não paira qualquer dúvida sobre a força normativa da afetividade, o que evidencia ser possível se extrair a necessária objetividade jurídica, esmo a partir de um tema que possui inerente subjetividade. Ou seja, o legislador não viu qualquer óbice na utilização da afetividade até mesmo como um dos critério objetivos a ser levado em conta no momento da decisão de processos judiciais (que pode envolver litígios e lida com situações que merecem especial atenção por envolver crianças e adolescentes). Não se percebe qualquer retração, dúvida ou cautela com uma suposta "subjetividade" ou "abstração" que seria inerente à afetividade, o que, para os que argumentam nesse sentido, impediria o Direito de trabalhar com tal conceito (como muitos sustentam). ${ }^{35}$
\end{abstract}

Essa realidade não tem sido aplicada apenas ao direito privado, mas também ao direito público. A TV do Tribunal Superior do Trabalho, em 03 de abril de 2009, anunciou que no dia 27 de março daquele ano, o Conselho Superior de Justiça do Trabalho concedeu licença adotante de 90 dias para um servidor do Tribunal Regional de Campinas, São Paulo, que é pai solteiro. Os conselheiros decidiram, por maioria de votos, que a decisão do caso concreto receberia caráter normativo e se estenderia para todos os servidores da Justiça do Trabalho na mesma situação. A decisão foi fundamentada no art. $5^{\circ}$ da Constituição que trata da isonomia entre homem e mulher e "ainda no melhor interesse da criança que necessita, no período de adaptação, desenvolver laços de afetividade com o seu pai ora adotante $^{, 36}$.

\footnotetext{
${ }^{35}$ CALDERÓN, Ricardo Lucas. Princípio da afetividade no direito de família. Rio de Janeiro: Renovar, 2013. p. 260.

${ }^{36}$ Decisão: ISTO POSTOACORDAM os Membros do Conselho Superior da Justic $\square$ a do Trabalho, I - por unanimidade: a) conhecer de ofício da matéria; b) no mérito, declarar a legalidade da decisão que reconheceu o direito à licenc $\square$ a de 90 (noventa) dias ao servidor solteiro, em razão da obtenc $\square \tilde{a}$ o da guarda, para fins de adoc $\square$ ão, de crianc $\square$ a com idade inferior a um ano; II por maioria, vencidos os Exmos. Conselheiros Vantuil Abdala e Milton de Moura Franc $\square$ a,
} 
Essa decisão projeta a afetividade no cenário jurídico estendendo-se até a Justiça do Trabalho, ramo de caráter público. Tal decisão acaba por transportar o afeto do plano existencial da vida das pessoas para o plano jurídico.

Além da importante decisão na área do Direito do Trabalho, outras recentes decisões marcam o novo sentido da relevância do afeto para o mundo jurídico.

Primeiramente, pode-se citar o caso da apelação cível em face da decretação da perda do poder familiar, julgado em 19.11.2008 e de relatoria da Exmo. Dr. Desembargador Vasco Della Giustina. Os pais biológicos recorreram da decisão que decretou a destituição do poder familiar sob o fundamento de que não apresentavam condições mínimas de prover o desenvolvimento saudável da filha menor. Entendeu o Tribunal de Justiça do Rio Grande do Sul que o vínculo biológico não tem condão de superar a necessidade do afeto, de uma vida digna, entre outros cuidados básicos.

Nessa decisão, o vínculo afetivo acabou por derrubar os laços consanguíneos ao buscar o melhor interessa do menor. Assim, através da decisão é possível observar que os laços afetivos se tornaram mais relevantes que os laços de sangue.

Outra decisão importante foi na apelação cível de uma disputa entre a família biológica e adotiva, datada de 13.08.2008, de relatoria do Desembargador Sérgio Fernando Vasconcelos Chaves. O caso envolvia a disputa da guarda de um menor e o Tribunal do Rio Grande do Sul entendeu por manter a guarda com a família substituta por estar lá adaptada há dez anos, sendo o local onde recebeu e recebe afeto e tem todas as necessidades atendidas. Para a mãe biológica, foi regulamentada as visitas para que pudesse estreitar sua relação com o menor. Através dessa decisão,

conferir efeito normativo ao presente acórdão, a fim de que seja editada Resoluc $\square$ ão por este Conselho Superior. Declarou-se impedido o Exmo. Conselheiro Luis Carlos Ca $\square$ ndido Martins Sotero da Silva. Brasília, 27 de marc $\square$ o de 2009. Decisão do Conselho Superior da Justica do Trabalho em 03.04.2009, referente ao processo n ${ }^{\circ}$ CSJT-150/2008-895-15-00.0. Disponível em <http://www.csjt.jus.br/c/document_library/get_file?uuid=e938572d-7979-4f8a-a9e9-

415116ac0979\&groupId=955023>. Acesso em 01 out. 2015. 
menor pôde desfrutar da família que lhe criou e também lhe forneceu a possiblidade de criar vínculos afetivos com sua mãe biológica.

Uma outra brilhante decisão que pode ser aqui destacada é a oriunda do agravo de instrumento de relatoria da então Desembargadora Maria Berenice Dias, proferida em 28.05.2008. A parte autora requer a regulamentação de visita da criança que fora adotada para que tenha convício com sua irmã que permaneceu no núcleo familiar biológico. A Des. relatora atentou ao fato de que apesar da adoção romper os vínculos com os pais e parentes, isto não significa que um pedido de regulamentação de visita configure em impossibilidade jurídica do pedido. Nesse sentido, a Des. entendeu que a manutenção dos vínculos de afeto com parentes biológicos devem ser preservados, uma vez que for comprovado que tal vem ao encontro dos interesses do adotando. A Des., então, afirmou que os vínculos de afeto devem ser somados, e não excluídos.

Nesse sentido, a família não é mais composta apenas por vínculos sanguíneos, mas também por laços de afeto, tornando o afeto e a família em dois personagens do novo cenário social e legal.

Essa dualidade de família e afeto é comentada por JOSÉ SEBASTIÃO DE OLIVEIRA, de uma forma muito interessante:

É dentro da família que os laços de afetividade tornam-se mais vigorosos e aptos a sustentar as vigas do relacionamento familiar contra males externos; é nela que seus membros recebem estímulo para pôr em prática suas aptidões pessoais. Daí então ser a característica da afetividade, aliada, por óbvio, à nuclearidade, a responsável pela plena realização pessoal de cada membro familiar. A afetividade faz com que a vida em família seja sentida de maneira mais intensa e sincera possível, e isto só será possível caso seus integrantes vivam apenas para si mesmo: cada um é o 'contribuinte' da felicidade de todos. ${ }^{37}$

$\mathrm{O}$ afeto, diferente do amor, engloba todos os sentimentos familiares. Assim, é importante estabelecer que o que foi jurisdicionado foi o afeto e não o amor. Nem sempre um familiar chega a alcançar o estado máximo

\footnotetext{
${ }^{37}$ OLIVEIRA, José Sebastião de, Fundamentos Constitucionais do Direito de Família. São Paulo: Revista dos Tribunais, 2002. p. 235
} 
que é o amor, mas o afeto deve estar presente para o efetivo cuidado necessário.

A tutela jurídica estatal não pode exigir o amor profundo e íntimo, mas pode exigir que haja a mera presença do afeto entre os membros de uma família. Com o afeto, é possível se exigir o cuidado e a atenção que são próprias para o bom desenvolvimento do caráter de uma criança em formação.

A afetividade se materializa no exercício dos valores humanitários, já que a solidariedade, por exemplo, advém do preceito maior de amor universal. Assim, quando a mesma Carta determina também o dever de amparo por todas as familiares aos idosos (não aos parentes, mas a qualquer idoso), assegurando sua integração na comunidade, defendendo sua dignidade e bem-estar e garantindolhes uma vida sadia, está autenticando mais uma vez o exercício da afetividade ${ }^{38}$.

É verdade que o modelo contemporâneo de família é inovador. De mera instituição, a família se tornou um espaço para desenvolvimento de afeto e companheirismo, passando a ser um local democrático que visa o livre desenvolvimento da personalidade de cada membro ou integrante.

Diante disso, há quem diga que se alterou do famialismo para o personalismo, ou seja, o membro tem seu espaço e individualidade reservado. Para tanto, o afeto se mostra como tijolo construtor de toda essa nova mecanicidade, se tornando como instrumento para a constituição e união familiar.

Portanto, erra quem afirma que a biologia gera afeto ou garante a sedimentação dos laços de filiação. A participação, o acolhimento emocional, a presença e a entrega são os responsáveis por gerar afeto e garantir a estruturação do status de filiação eo reconhecimento do afeto como valor jurídico se mostra como uma consequência da necessidade apresentada pelas mudanças sociais.

\footnotetext{
${ }^{38} \mathrm{KAROW}$, Aline Biasuz Suarez. Abandono afetivo: valorização do afeto nas relações paternofiliais. Curitiba: Juruá, 2012, p. 131-132.
} 


\subsection{A Patrimonialização do Afeto}

Uma dúvida que paira nos julgadores e nos estudiosos do tema sobre do abandono afetivo é acerca da possibilidade de monetarização das relações familiares, isto é, da conversão em pecúnia dos sentimentos mais íntimos que justificam a proximidade das pessoas relacionadas entre si por verdadeiros vínculos afetivos.

Transformar o afeto em valor jurídico é algo natural e necessário e é consequência das mudanças sociais, porém monetizá-lo se mostra como um ponto de maior controvérsia e discussão.

Neste aspecto, dissertar sobre afeto não é uma tarefa fácil, mas monetizá-lo se mostra como uma tarefa ainda mais difícil. Por essa razão, reais e razoáveis dúvidas surgem sobre a viabilidade jurídica de conversão do afeto em patrimônio. Importante destacar que inexiste, efetivamente, no ordenamento em vigor, qualquer obrigação legal de afeto, amor ou qualquer outro sentimento do gênero dos pais aos seus filhos.

Assim, o Poder Judiciário, ao estabelecer parâmetros patrimoniais à falta do afeto estaria, por obvio, patrimonializado um sentimento, qual seja, o afeto.

Entretanto, tal premissa parece absurda, pois seria duvidoso exigir de alguém que ame e tenha afeto de outem. Na realidade, porém, não se estaria a exigir amor, afeto ou algum outro sentimento subjetivo e inalcançável por meio das controvérsias judiciais, mas o cumprimento do dever jurídico do cuidado, inerente ao poder familiar, como vínculo jurídico que une pais e filhos.

Assim, parte da doutrina e da jurisprudência assenta-se na premissa de que não se estaria sendo exigido sentimentos, mas os deveres de criação, convívio, educação e acompanhamento dos filhos, com o fito de garantir a proteção e o saudável desenvolvimento dos mesmos. Tais deveres são 
atribuições decorrentes de uma paternidade responsável plasmada por valores previstos em nosso vigente texto constitucional.

De fato, os deveres jurídicos dos pais para com seus filhos estão previstos no artigo 1.634 do Código Civil $^{39}$, sendo possível prever que a atenção, o cuidado, o cumprimento de obrigações para com a formação social e psicológica do individuo estão inseridas no bojo da paternidade e maternidade responsáveis.

\section{CESAR AUGUSTO DE OLIVEIRA QUEIROZ ROSALINO, em} seu artigo publicado em junho de 2012, defende a impossibilidade de se exigir cuidado sem afeto. Além disso, afirma que dever jurídico algum respalda o ato de um pai ou uma mãe a levar seu filho de madrugada ao hospital, que senão o amor existente desse vínculo, já que ninguém cuida de uma criança por mera obrigação legal.

Impossível exigir cuidado sem afeto. Tal construção se mostra artificial, resvala em ficcionismo, uma vez que, ninguém cuida, cria, educa ou acompanha uma criança por mera obrigação jurídica, mas sim, porque mantém com esta, uma genuína e verdadeira relação de afetividade, de amor, de interesse participativo em seu desenvolvimento sócio-psicológico.

Alguém ousaria afirmar que o que move um pai ou uma mãe a comparecer a uma reunião de escola, ou a levar seu filho ao médico de madrugada consiste no mero cumprimento de um dever jurídico ${ }^{40}$

\footnotetext{
${ }^{39}$ Art. 1.634. Compete a ambos os pais, qualquer que seja a sua situação conjugal, o pleno exercício do poder familiar, que consiste em, quanto aos filhos:

I - dirigir-lhes a criação e a educação;

II - exercer a guarda unilateral ou compartilhada nos termos do art. 1.584;

III - conceder-lhes ou negar-lhes consentimento para casarem;

IV - conceder-lhes ou negar-lhes consentimento para viajarem ao exterior;

$\mathrm{V}$ - conceder-lhes ou negar-lhes consentimento para mudarem sua residência permanente para outro Município;

VI - nomear-lhes tutor por testamento ou documento autêntico, se o outro dos pais não lhe sobreviver, ou o sobrevivo não puder exercer o poder familiar;

VII - representá-los judicial e extrajudicialmente até os 16 (dezesseis) anos, nos atos da vida civil, e assisti-los, após essa idade, nos atos em que forem partes, suprindo-lhes o consentimento;

VIII - reclamá-los de quem ilegalmente os detenha;

IX - exigir que lhes prestem obediência, respeito e os serviços próprios de sua idade e condição.

${ }^{40}$ ROSALINO, Cesar Augusto de Oliveira Queiroz, A gente não quer só dinheiro, a gente quer dinheiro e felicidade:como a patrimonialização do afeto pode interferir nas relações familiare. Disponível em <http://jus.com.br/artigos/22080/a-gente-nao-quer-so-dinheiro-a-gente-querdinheiro-e-felicidade\#ixzz3n2tZxScz>. Acesso em 28 set. 2015.
} 
Por outro lado, MARIA BERENICE ${ }^{41}$, bem destacando, traz a problemática da monetarização do afeto ao tratar da possível repercussão jurídica do namoro e da possibilidade de celebração de um contrato de namoro. A autora diz que é possível que duas pessoas celebrem um contrato de namoro justamente para afastar a incidência de eventual caracterização de união estável.

Para parte da doutrina, essa pactuação é completamente inválida, já que a incidência da união estável se mostra como um preceito de ordem pública. Mesmo que, de início, a intenção do casal no seja apenas o namoro, pode ser que ao longo do tempo evidenciem-se os elementos caracterizadores da união estável.

É nesse sentido que leciona HELDER COL:

Alias nenhuma união nasce já estável. Ela se torna estável. Nenhuma união nasce duradoura, mas torna-se tal se persistir no tempo. Mesmo os namoros 'moderninhos', que já começam íntimos, regidos pelo sexo, possuem grande possibilidade de desfazimento, só se tornando efetivos, estáveis e duradouros com a superação dos desencontros naturais de personalidade dos parceiros, ao longo do tempo. ${ }^{42}$

Sobre o tema, MARIA BERENICE,é precisa ao afirmar que "o contrato de namoro é algo inexistente e desprovido de eficácia no seio do ordenamento jurídico ${ }^{43,}$. Para a autora o negócio jurídico serve apenas para monetizar o afeto e transformá-lo em pecúnia em eventual inadimplemento ou quebra do acordado.

Assim, há quem entenda que a possível patrimonialização do afeto somente traz consequências indesejadas, como por exemplo o questionamento de que muitas vezes a omissão dos pais em relação ao filho que jamais desejou se mostra como mais vantajoso do que impor o cuidado

\footnotetext{
${ }^{41}$ DIAS. Maria Berenice. Manual de Direito das Famílias. $8^{\mathrm{a}}$ Edição. Revista, atualizada e ampliada. São Paulo: Editora Revista dos Tribunais, 2011, p. 182.

${ }^{42}$ COL, Helder Martinez da. Contrato de Namoro. Revista Brasileira de Direito de Família: IBDFAM, Porto Alegre, n. , p.126-156, 01 abr. 2004, p. 146.

${ }^{43}$ DIAS. Maria Berenice. Manual de Direito das Famílias. $8^{\mathrm{a}}$ Edição. Revista, atualizada e ampliada. São Paulo: Editora Revista dos Tribunais, 2011, p. 186.
} 
e a atenção por meio de reais sanções no bolso daquele que não deseja fornecer o cuidado.

Para essa parcela dos defensores da impossibilidade da patrimonialização do afeto, o que se quer demonstrar é que nem sempre a presença de alguém que efetivamente não queria estar ali será algo vantajoso.

Parece muito agressivo o posicionamento contrário através desse entendimento, sendo muito mais coerente o questionamento da monetarização do afeto através do prisma de que se abriria um grande leque de possibilidades para futuras demandas que se abririam quando se admite a indenização em questões altamente subjetivas como as afetivas.

Por essa razão, a discussão sobre a patrimonialização requer muita atenção, já que guarda polêmica e argumentos fortes para ambos os lados. 


\title{
Capítulo II - NOÇÕES FUNDAMENTAIS DE RESPONSABILIDADE CIVIL E SUA APLICAÇÃO NAS RELAÇÕES FAMILIARES
}

\subsection{A Evolução da Responsabilidade Civil nas Relações Familiares}

Entre todas as relações sociais que se desenvolveram e aperfeiçoaram nesses últimos tempos é certo que aquela que mais se destacou e sofreu alterações foi a relação familiar. A família, como representação do núcleo social, apresenta-se mais dinâmica, versátil, flexível e, por isso, consegue refletir de forma mais efetiva os anseios e as mudanças da sociedade.

\begin{abstract}
Segundo leciona VENOSA,
O organismo familiar passa por constantes mutações e é evidente que o legislador deve estar atento as necessidades de alterações legislativas que devem ser feitas no curso deste século. Não pode também o Estado deixar de cumprir sua permanente função social de proteção á família, como sua célula manter, sob pena de o próprio Estado desaparecer cedendo lugar ao $\operatorname{caos}^{44}$
\end{abstract}

Através das palavras de VENOSA, se pode compreender que o Direito, mais precisamente, o Direito de Família decorrência imediata da evolução social. Nesse sentido, se pode afirmar que:

o direito de família apresenta-se como um conjunto integrado de normas que regulamenta as relações jurídicas familiares, o que lhe impossibilita negar os novos contornos que afloram no seio familiar. Atentando, principalmente, na interpretação e aplicação das normas de direito de família coadunadas as essas transformações sociais ${ }^{45}$.

Nesse sentido, não há possibilidade de se compreender o Direito de

\footnotetext{
${ }^{44}$ VENOSA, Sílvio de Salvo.Direito civil. Direito de Família. 7. ed. São Paulo: Atlas, 2007.v.6. p. 10.

${ }^{45}$ RIBEIRO, Karolyne Moraes. A evolução e os aspectos contemporâneos da responsabilidade civil no direito de família. Disponível em <http://www.ambitojuridico.com.br/site/?n_link=revista_artigos_leitura\&artigo_id=10815>. Acesso em 28 set. 2015.
} 
Família sem se conceder a ideia de que os valores que o fundamentam e que servem de base para sua estrutura social são frutos das relações familiares. Por isso que o direito de família é um dos ramos jurídicos que mais atendem aos anseios sociais e, consequentemente, necessitam alterações legislativas a todo instante.

Antigamente, em tempos não tão distantes, não havia espaço para a discussão acerca da responsabilidade civil no âmbito do direito de família. Se entendia que as relações surgidas no âmbito familiar eram tão intocáveis e pessoais que nem normas de direito podiam toca-las.

Sendo assim, por muito tempo entendeu-se que as regras da responsabilidade civil nas relações jurídicas oriundas no âmbito familiar não eram cabíveis.

Aplicavam-se ao Direito de Família apenas as suas regras próprias e específicas. Como exemplo, o cônjuge culpado, diante da violação de um dos deveres conjugais, iria receber como consequências e punições a dissolução do casamento, a perda da guarda dos filhos, além disso, responderia pelos honorários correspondentes a ação em que foi vencido. Não iria, entretanto, ser imposto nada referente ao instituto da responsabilidade civil. Assim, se este tivesse gerado um dano material ou moral ao seu cônjuge, a ele não seria imposto o dever de reparar tal dano.

Com o passar do tempo, em função de uma nova ordem econômica e social, as relações familiares passaram a sofrer incidência das regras da responsabilidade civil.

Logo, é inconcebível não admitirmos que diante da ação/omissão ilícita/lícita da qual surja o dano e haja o nexo causal entre eles não possa nascer o dever de consertar o mal causado só pelo fato de um ser o cônjuge do outro, ou seja, só porque a violência nasceu entre familiares não se pode deixar de exigir que o causador do dano repare o que fez ${ }^{46}$.

Nesta mesma concepção, o ilustre autor BERNARDO BRANCO

\footnotetext{
${ }^{46}$ RIBEIRO, Karolyne Moraes. A evolução e os aspectos contemporâneos da responsabilidade civil no direito de família. Disponível em <http://www.ambitojuridico.com.br/site/?n_link=revista_artigos_leitura\&artigo_id=10815>. Acesso em 30 set. 2015.
} 
ensina que:

Erroneamente cultivou-se a ideia de que as relações jurídicas, no âmbito de família, por sua natureza marcadamente extrapatrimonial, não admitiriam a aplicação dos princípios que embasam a responsabilidade civil, cabendo aos institutos próprios desse ramo de Direito, como o dos danos causados a um de seus membros pelo comportamento antijurídico do outro ${ }^{47}$.

Pela leitura do Código Civil, percebe-se que oart. 932 estabelece que os pais são responsáveis pelos filhos menores que estiverem sob sua autoridadee em sua companhia. O conceito de autoridade, previsto no dispositivo, prevê quem é titular do poder familiar.É exigência que o menor esteja na companhia do pai ou mãe.Na hipótese de pais separados, o requisito da companhia depende de prova, para verificar se o menor causou o dano no momento que estava com o guardião ou com o outro.

Para o STJ, a responsabilidade civil dos pais se assenta na presunção relativa de culpa e de culpa in vigilando, que podem ser afastadas se ficar provado que os pais não agiram de forma negligente no dever de guarda. Tal premissa pode ser observada no REsp 777327. O caso concreto versa sobre o relato de que a genitora (guardiã) adquirira um revólver de modo irregular e após guarda-lo sem cautela, seu filho menor o utilizou indevidamente e causou dano a outrem. O caso concreto prevê a exoneração do pai (não guardião) de responder solidariamente pelo ato ilícito cometido pelo filho menor.

Em se tratando de divórcio, 'que tem como efeito imediato a determinação unilateral da autoridade parental - via colocação do filho sob a guarda de um dos genitores - não há mais que se falar em solidariedade, já que a partir do momento em que se instaura a guarda unilateral, sobre aquele genitor recai a presunção de responsabilidade: se a criança praticou um dano é porque o genitor cometeu um erro na sua educação ou na fiscalização de sua pessoa, ${ }^{48}$.

Além disso, o Código Civil de 2002 introduziu norma no sentido de que o incapaz responde diretamente pelos prejuízos que causar, caso seus responsáveisnão dispuserem de meios suficientes. O menor irá responder

\footnotetext{
${ }^{47}$ BRANCO, Bernardo Castelo. Dano moral no direito de família. São Paulo: Método, 2006. p. 18

${ }^{48}$ LÔBO, Paulo. Op. cit., p. 313
} 
com doação, legado ou herança de valor expressivo recebido, caso seus responsáveis não detenham recursos suficientes para a reparação do dano causado.

Além disso, entende-se que os pais respondem pelos danos que seus filhos menores venham causar. Por isso, conceitua a responsabilidade dos pais nessas hipóteses como sendo uma responsabilidade civil transubjetiva, isto é, imputa-se a responsabilidade a quem não causou diretamente o dano.

O poder familiar não apenas diz respeito às relações entre pais e filhos. Interessam suas repercussões patrimoniais em relação a terceiros. Os pais respondem pelos danos causados por seus filhos menores, que estejam submetidos a seu poder familiar. Trata-se de responsabilidade civil transubjetiva, pois a responsabilidade pela reparação é imputável a quem não causou diretamente o dano ${ }^{49}$.

Portanto, tem-se que a responsabilidade civil é plenamente possível e aplicável às situações oriundas das relações familiares, bastando, para isso, que estejam presente os pressupostos indispensáveis para a caracterização do instituto.

\subsection{Pressupostos Gerais da Responsabilidade Civil}

Ninguém melhor do que SÉRGIO CAVALIERI FILHO para elucidar o conceito e os pressupostos gerais da responsabilidade civil no direito brasileiro. Para tanto, o douto autor explica que é no sentimento de justiça que se inspira a responsabilidade civil.

O anseio de obrigar o agente, causador do dano, a repará-lo inspira-se no mais elementar sentimento de justiça. $\mathrm{O}$ dano causado pelo ato ilícito rompe o equilíbrio jurídico-econômico anteriormente existente entre o agente e a vítima. Há uma necessidade fundamental de se restabelecer esse equilíbrio, o que se procura fazer recolocando o prejudicado no statu quo ante. Impera neste campo o principio da restitutio in integrum, isto é, tanto quanto possível, repõe-se a vítima à situação anterior à lesão. Isso se faz através de uma indenização fixada em proporção ao dano. Indenizar pela metade é responsabilizar a vítima pelo resto (Daniel Pizzaro, in Danos, 1991). Limitar a reparação é impor à vítima que suporte o resto dos prejuízos não indenizados ${ }^{50}$.

\footnotetext{
${ }^{49}$ LÔBO, Paulo. Op. cit., p.312.

${ }^{50}$ CAVALIERI FILHO, Sérgio. Programa de responsabilidade civil. 10 ed. São Paulo: Atlas, 2012. p.14.
} 


\begin{abstract}
Além disso, CAVALIERI, em referência a San Tiago Dantas, esclarece que o principal objetivo da ordem jurídica é proteger o lícito e reprimir o ilícito.
\end{abstract}

O principal objetivo da ordem jurídica, afirmou San Tiago Dantas, é proteger o lícito e reprimir o ilícito. Vale dizer: ao mesmo tempo em que ela se empenha em tutelar a atividade do homem que se comporta de acordo com o Direito, reprime a conduta daquele que o contraria (Programa de Direito Civil, v. I/341, Ed. Rio). Podemos sintetizar a lição desse grande Mestre dizendo que o Direito se destina aos atos lícitos; cuida dos ilícitos pela necessidade de reprimi-los e corrigir os seus efeitos nocivos.

Para atingir esse desiderato, a ordem jurídica estabelece deveres que, conforme a natureza do direito a que correspondem, podem ser positivos, de dar ou fazer, como negativos, de não fazer ou tolerar alguma coisa. Fala-se, até, em um dever geral de não prejudicar a ninguém, expresso pelo Direito Romano através da máxima neminem laedere.

Alguns desses deveres atingem a todos indistintamente, como no caso dos direitos absolutos; outros, nos direitos relativos, atingem a pessoa ou pessoas determinadas. ${ }^{51}$

Nesse sentido, a responsabilidade civil surge quando um dever jurídico é violado e, em decorrência de tal violação, um dano é causado a outrem. Ou seja, a violação de um dever jurídico originário configura o ilícito, acarretando um novo dever jurídico, que passa a ser chamado de secundário e pressupõe a reparação do dano causado. SÉRGIO

CAVALIERI, continua brilhante em sua explanação:

A violação de um dever jurídico configura o ilícito, que, quase sempre, acarretadano para outrem, gerando um novo dever jurídico, qual seja, o de reparar o dano Há, assim, um dever jurídico originário, chamado por alguns de primário, cuja violação gera um dever jurídico sucessivo, também chamado de secundário, queé o de indenizar o prejuízo. A título de exemplo, lembramos que todos têm o dever de respeitar a integridade física do ser humano. Tem-se, aí, um dever jurídico originário, correspondente a um direito absoluto. Para aquele que descumprir esse dever surgirá um outro dever jurídico: o da reparação do dano.

É aqui que entra a noção de responsabilidade civil. Em seu sentido etimológico,responsabilidade exprime a ideia de obrigação, encargo, contraprestação. Em sentido jurídico, o vocábulo não foge dessa ideia. A essência da responsabilidadeestá ligada à noção de desvio de conduta, ou seja, foi ela engendrada para alcançar as condutas praticadas de forma contrária ao direito e danosas a outrem. Designa o dever que alguém tem de reparar o prejuízo decorrente da violação de um outro dever jurídico. Em apertada síntese, responsabilidade civil é um dever jurídico sucessivo que surge para recompor o dano decorrente da violação de um dever jurídico originário. ${ }^{52}$

\footnotetext{
${ }^{51}$ Ibid. p. 1

${ }^{52}$ Ibid. p. 2
} 
Cabe lembrar que obrigação não é sinônimo de responsabilidade. Obrigação é sempre um dever jurídico originário e a responsabilidade, por sua vez, é um dever jurídico sucessivo, consequente à violação do primeiro.

Além disso, importante destacar que a doutrina entende que a responsabilidade tem um elemento nuclear comum, isto é, pressupõe sempre uma conduta voluntária violadora de um dever jurídico, mas divide a responsabilidade em diversas espécies dependendo de onde provém esse dever e qual o elemento subjetivo dessa conduta.

Para o presente trabalho, importante se mostra a dicotomia entre a responsabilidade contratual e extracontratual. CAVALIERI, sobre o tema, discorre que:

Quem infringe dever jurídico lato sensu, já vimos, de que resulte dano a outrem fica obrigado a indenizar. Esse dever, passível de violação, pode ter como fonte uma relação jurídica obrigacional preexistente, isto é, um dever oriundo decontrato, ou, por outro lado, pode ter por causa geradora uma obrigação impostapor preceito geral de Direito, ou pela própria lei.

É com base nessa dicotomia que a doutrina divide a responsabilidade civilem contratual e extracontratual, isto é, de acordo com a qualidade da violação. Se preexiste um vínculo obrigacional, e o dever de indenizar é consequência doinadimplemento, ternos a responsabilidade contratual, também chamada de ilícitocontratual ou relativo; se esse dever surge em virtude de lesão a direito subjetivo,sem que entre o ofensor e a vítima preexista qualquer relação jurídica que opossibilite, ternos a responsabilidade extracontratual, também chamada de ilícitoaquiliano ou absoluto.

Na precisa lição do professor Ricardo Pereira Lira, o dever jurídico pode surgir da lei ou da vontade dos indivíduos. Nesse último caso, os indivíduos criam para si deveres jurídicos, contraindo obrigações em negócios jurídicos, que são os contratos e as manifestações unilaterais de vontade. ${ }^{53}$

Além de tal dicotomia, se faz relevante elucidar a diferença entre a responsabilidade civil objetiva e subjetiva. Fato é que a ideia de culpa está intimamente ligada à responsabilidade e, por tal fato, via de regra, ninguém deve merecer sanção ou juízo de reprovação sem que tenha faltado com o dever de cautela em seu agir. Por esse motivo, a culpa é o principal pressuposto da responsabilidade civil subjetiva.

\footnotetext{
${ }^{53}$ Ibid. p. 16
} 
Através dessa concepção clássica de responsabilidade, a vítima somente obterá reparação do dano caso prove a culpa do agente. Tal obrigação probatóriaacarreta uma grande dificuldade para aquele que pretende a reparação. Por isso, diante de tal dificuldade, importantes trabalhos começaram a ser desenvolvidos na Itália, na Bélgica e, sobretudo, na França sustentando uma responsabilidade objetiva, sem culpa, baseada na chamada teoria do risco, que acabou sendo também adotada pela lei brasileira em certos casos e pelo Código Civil no parágrafo único do seu art. 927, art. 931 entre outros dispositivos.

Além de tais espécies de responsabilidade, há ainda a responsabilidade nas relações de consumo. Sobre o tema, CAVALIERI diz que:

(...) é possível dizer que o Código de Defesa do Consumidor trouxe a lume uma nova área da responsabilidade civil - a responsabilidade nas relações de consumo -, tão vasta que não haveria nenhum exagero em dizer estar hoje a responsabilidade civil dividida em duas partes: a responsabilidade tradicional e a responsabilidade nas relações de consumo.

Veremos que a responsabilidade estabelecida no Código de Defesa do Consumidor é objetiva, fundada no dever e segurança do fornecedor em relação aos produtos e serviços lançados no mercado de consumo, razão pela qual não seria também demasiado afirmar que, a partir dele, a responsabilidade objetiva, que era exceção em nosso Direito, passou a ter um campo de incidência mais vasto do que a própria responsabilidade subjetiva. ${ }^{54}$

Assim, o Código de Defesa do Consumidor, Lei 8.078/90, estabelece a responsabilidade objetiva do fornecedor e do fabricante, desconsiderando o elemento culpa, conforme o constante nos artigos 12 e 14 do referido diploma:

Art. 12. O fabricante, o produtor, o construtor, nacional ou estrangeiro, e o importador respondem, independentemente da existência de culpa, pela reparação dos danos causados aos consumidores por defeitos decorrentes de projeto, fabricação, construção, montagem, fórmulas, manipulação, apresentação ou acondicionamento de seus produtos, bem como por informações insuficientes ou inadequadas sobre sua utilização e riscos.

Art. 14. O fornecedor de serviços responde, independentemente da existência de culpa, pela reparação dos danos causados aos consumidores por defeitos relativos

\footnotetext{
${ }^{54}$ Ibid. p. 18
} 
à prestação dos serviços, bem como por informações insuficientes ou inadequadas sobre sua fruição e riscos.

\subsubsection{Conduta llícita}

A conduta humana se revela como elemento primário de todo ato ilícito e, por consequência, da responsabilidade civil. Entende-se por conduta o comportamento humano voluntário, que se exterioriza através de uma ação ou omissão, produzindo consequências jurídicas ${ }^{55}$.

\section{Maria Helena Diniz entende por conduta:}

A ação, elemento constitutivo da responsabilidade, vem a ser o ato humano, comissivo ou omissivo, ilícito ou licito, voluntario e objetivamente imputável do próprio agente ou de terceiro, ou o fato de animal ou coisa inanimada, que cause dano a outrem, gerando o dever de satisfazer os direitos do lesado. ${ }^{56}$

Como já esclarecido, a responsabilidade decorrente do ato ilícito baseia-se na ideia de culpa, diferentemente da responsabilidade sem culpa, essa última baseada no risco. $\mathrm{O}$ ato comissivo é o ato pelo qual o agente exerce ativamente a violação de um dever, enquanto a omissão é a não observância ou a falta de um dever.

Assim, a voluntariedade se mostra como uma qualidade essencial da conduta humana, pois representa a liberdade de escolha do agente. Sabe-se que inexistindo tal elemento não haveria de se falar em ação humana ou responsabilidade civil.

Não constituem conduta, porém, os atos em que não intervém a menor parcela de vontade, os denominados atos reflexos, como nos casos de sonambulismo, hipnose e outros estados de inconsciência. A coação física absoluta/irresistível também não pressupõe conduta, hipótese na qual o ato não será do coator, mas de quem dele se serviu como instrumento.

\footnotetext{
${ }^{55}$ SANTOS, Pablo de Paula Saul. Responsabilidade civil: origem e pressupostos gerais. Disponível em: <http://www.ambitojuridico.com.br/site/?n_link=revista_artigos_leitura\&artigo_id=11875>. Acesso em 14 set. 2015 ${ }^{56}$ DINIZ, Maria Helena. Curso de Direito Civil Brasileiro - Responsabilidade Civil. 19 ed. São Paulo: Saraiva, 2005. VII, p. 43.
} 
Sobre o tema, Pablo de Paula Santos diz que:

$\mathrm{O}$ ato de vontade, em sede de responsabilidade civil, deve ser contrário ao ordenamento jurídico. É importante ressaltar que voluntariedade significa pura e simplesmente o discernimento, a consciência da ação, e não a consciência de causar um resultado danoso sendo este o conceito de dolo. Cabe destacar ainda, que a voluntariedade deve estar presente tanto na responsabilidade civil subjetiva quanto na responsabilidade objetiva. ${ }^{57}$

Portanto, a conduta humana, seja ação ou omissão, é o ato da pessoa que causa dano ou prejuízo a outrem. Tal conduta gravosa gera a obrigação de reparação. Nessa esteira, a conduta humana pode tanto ser no sentido da prática de ato que não deveria ter sido feito, como no sentido de deixar de praticar ato que deveria ter sido feito e por isso, toda a conduta ilícita envolve o conceito de culpa.

MARCELO CALIXTO ${ }^{58}$ defende o trinômio conduta ilícita, dano e nexo causal como pressupostos da responsabilidade civil, não havendo diferenciação entre a conduta ilícita e a culpa. Tal entendimento diverge do sustentado por CAVALIERI que diferencia a conduta ilícita da culpa, elencando quatro pressupostos para a responsabilidade civil: (i) conduta ilícita; (ii) culpa; (iii) dano e (iv) nexo causal.

Como a culpa é decorrência direta de uma conduta que faltou com o dever de cuidado, não há motivos para a diferenciação entre a conduta ilícita e a culpa, se mostrando mais coerente a corrente adotada pelo Professor Calixto, a qual não as diferenciam como pressupostos diversos da responsabilidade civil. Nesse sentido, cabe, aqui, explicitar o conceito de culpa.

A caracterização da culpa é de grande dificuldade. Culpa, em apertada síntese, é a violação de dever objetivo de cuidado, que o agente podia conhecer e observar. Outra conceituação seria a omissão de diligência exigível.

\footnotetext{
${ }^{57}$ SANTOS, Pablo de Paula Saul. Responsabilidade civil: origem e pressupostos gerais. Disponível em: <http://www.ambitojuridico.com.br/site/?n_link=revista_artigos_leitura\&artigo_id=11875>. Acesso em 14 set. 2015 ${ }^{58}$ CALIXTO, Marcelo Junqueira. A culpa na responsabilidade civil: estrutura e função. Rio de Janeiro: Renovar, 2008.
} 
A culpa em seu sentido lato abrange tanto o dolo como a culpa em sentido estrito. $\mathrm{O}$ dolo e a culpa pressupõe, necessariamente, uma conduta voluntária do agente e se diferenciam de acordo com a presença ou a ausência da intenção de provocar determinado resultado.

Assim, enquanto o dolo pressupõe a intenção e a conduta já nasce sendo ilícita, a culpa pressupõe o descumprimento do dever de cuidado que acaba por gerar um resultado danoso.

CAVALIERI conceitua bem o dolo como sendo "uma vontade conscientemente dirigida à produção de um resultado ilícito. É a infração consciente do dever preexistente, ou o propósito de causar dano a outrem $^{59,}$

Assim, tem-se a conclusão que o dolo necessariamente pressupõe a vontade, a intenção do agente em ver sendo causado o resultado e tem a consciência de que ele é ilícito.

Já a culpa, por sua vez, abrange dois conceitos, quais sejam, a culpa subjetiva ou culpa psicológica e a culpa objetiva ou culpa normativa. A primeira consiste em avaliar o agente e descobrir se seria possível a prática de outro ato que não o cometido. A culpa normativa, por sua via, surgiu posteriormente e ao invés de colocar em foco o agente e passa a entender a culpa como sendo um erro de conduta que não seria cometido por um ser humano, ou seja, como sendo um desvio de conduta.

Cabe ressaltar que independe de objetiva ou subjetiva, a culpa se compõe por um elemento objetivo que é o ato contrário ao direito, pressupondo a ideia de violação de um dever. Além do elemento objetivo, há o elemento subjetivo, que trata-se da imputabilidade. Sendo assim, a culpa pressupõe um desvio de conduta e uma violação do dever de cuidado.

Atualmente se divide a culpa, violação do dever de cuidado, em três modalidades: (i) imprudência - ausência de cautela em decorrência de uma conduta comissiva; (ii) negligência - falta de cautela em razão de uma omissão e (iii) imperícia - falta de habilidade técnica e específica.

${ }^{59}$ CAVALIERI FILHO, Sérgio. Op. cit., p. 32 
Além das modalidades de culpa supracitadas, há ainda a diferenciação por gravidade, ou seja, existe a culpa grave que consiste na ideia de existência de um erro grosseiro e evidente. SERGIO CAVALIERI também denomina a culpa grave como "culpa consciente"60 que se assemelha ao dolo eventual, instituto do Direito Penal.

A culpa leve seria o segundo grau na escala de gravidade. A culpa leve pressupõe a conduta que não seria cometida por um homem prudente. Já o terceiro grau de culpa é a culpa levíssima. Essa última consiste na conduta evitável por um ser humano diligente, "caracteriza-se pela falta de atenção extraordinária, pela ausência de habilidade e especial conhecimento singular",61

Como explicado no item 2.2.1, a conduta culposa do agente é pressuposto principal da obrigação de indenizar. Isso significa que nem todo comportamento do agente será apto a gerar o dever de indenizar, mas somente aquele que estiver revestido de certas características previstas na ordem jurídica. A vitima de um dano só poderá pleitear ressarcimento de alguém na hipótese de êxito em provar que esse alguém agiu com culpa. Na hipótese de impossibilidade de provar a culpa, não será possível pleitear o ressarcimento do dano e deverá o suportar sozinho.

Um ponto relevante a ser abordado é acerca da controvérsia existente quanto a influência do grau da culpa na quantificação da indenização a ser arbitrada pelo Poder Judiciário no caso concreto. A controvérsia surgiu com o Código Civil de 2002, que em seu art. 944, parágrafo único, prevê a possibilidade do magistrado aumentar ou reduzir o valor da indenização de acordo com a gradação e a gravidade da culpa.

Essa possiblidade do juiz de determinar o valor da indenização de acordo com a gravidade da culpa é rechaçada por parte da doutrina, incluindo entre ela o grande mestre MARCELO CALIXTO ${ }^{62}$, bem como

\footnotetext{
${ }^{60}$ CAVALIERI FILHO, Sérgio. Op. cit., p. 39

${ }^{61}$ CAVALIERI FILHO, Sérgio. Op. cit., p. 40

${ }^{62}$ CALIXTO, Marcelo Junqueira. A culpa na responsabilidade civil: estrutura e função. Rio de Janeiro: Renovar, 2008, p. 309-310; 318-321; 323.
} 
por parte da jurisprudência. Para fundamentar essa corrente, se entende que a "a medida da indenização seria o dano e não o grau de reprovabilidade da conduta". 63

\begin{abstract}
Afirma-se que a reduc $\square$ ão da indenizac $\square$ ão com base no grau de culpa acarretaria inseguranc $\square$ a jurídica, pois remeteria à razoabilidade ou ao bom senso a definição do grau de culpa, além de criar injustiças, pois que danos de grandes proporções podem ser causados por culpa leve ou levíssima, ao passo que a culpa grave pode ocasionar danos de pequena monta. Assim, a regra, no ordenamento jurídico brasileiro, continua a ser a do caput do art. 944, de modo que a norma do parágrafo único, se interpretada literalmente, revelar-se-ia inconstitucional, vez que viola o princípio da reparação integral do dano sofrido, fundado na cláusula geral de tutela da pessoa humana, constitucionalmente prevista (CF, art. 1o, III), que deve ser o grande norte do julgador ao fixar o montante da reparação. ${ }^{64}$
\end{abstract}

Assim, melhor seria a fixação do quantum a ser indenizado através da extensão do dano. Cabe ressaltar que sempre haverá a possibilidade de reduzir a indenização através da utilização da cláusula geral da equidade. Nesse sentido, na hipótese de existência de desproporção entre a extensão do dano e o grau de culpa, o magistrado poderá, através da equidade, reduzir a indenização.

Tem-se que o conceito de culpa é um dos conceitos mais difíceis de serem alcançados no direito civil, mas ele se faz necessário, na medida em que representa um dos pressupostos da responsabilidade civil.

\title{
2.2.2 Dano
}

$\mathrm{O}$ segundo pressuposto é o dano. $\mathrm{O}$ dano é requisito essencial para a configuração da responsabilidade civil, não sendo possível se falar em indenização, nem em ressarcimento sem a existência do dano.

A Constituição Federal assegura no caput do artigo $5^{\circ}$ e inciso $\mathrm{X}$ o direito a reparação do dano, seja ele moral ou material:

\footnotetext{
${ }^{63}$ MELO, Marco Aurélio Bezerra de. Curso de Direito Civil. Responsabilidade Civil, v. IV, São Paulo: Atlas, 2015. p. 46.

${ }^{64}$ CALIXTO, Marcelo Junqueira, 2008 apud BANDEIRA, Paula Greco. A evolução do conceito de culpa e o artigo 944 do Código Civil. Disponível em $<$ http://www.emerj.tjrj.jus.br/revistaemerj_online/edicoes/revista42/Revista42_227.pdf >. Acesso em 21 out. 2015.
} 
Art. $5^{\circ}$. Todos são iguais perante a lei, sem distinção de qualquer natureza, garantindo-se aos brasileiros e aos estrangeiros residentes no País a inviolabilidade do direito á vida, à igualdade, à segurança e a propriedade, nos termos seguintes:

(...)

$\mathrm{X}$ - são invioláveis a intimidade, a vida privada, a honra e a imagem das pessoas, assegurado o direito a indenização pelo dano material ou moral decorrente de sua violação;

O dano é o prejuízo resultante da lesão a um bem ou direito, sendo a perda ou diminuição do patrimônio material ou moral do lesado em decorrência da conduta do agente. Tal conduta gera, para o lesado, o direito de ser ressarcido para que haja o retorno de sua situação ao estado em que se encontrava antes do dano ou para que seja compensado caso não exista possibilidade de reparação.

\section{Conforme o ensinamento de SERGIO CAVALIERI:}

$\mathrm{O}$ ato ilícito nunca será aquilo que os penalistas chamam de crime de mera conduta; será sempre um delito material, com resultado de dano. Sem dano pode haver responsabilidade penal, mas não há responsabilidade civil. Indenização sem dano importaria enriquecimento ilícito; enriquecimento sem causa para quem a recebesse e pena para quem a pagasse, porquanto o objetivo da indenização, sabemos todos, é reparar o prejuízo sofrido pela vítima, reintegrá-la ao estado em que se encontrava antes da prática do ato ilícito. $\mathrm{E}$, se a vítima não sofreu nenhum prejuízo, a toda evidência, não haverá o que ressarcir. Daí a afirmação, comum a praticamente todos os autores, de que o dano é não somente o fato constitutivo mas, também, determinante do dever de indenizar ${ }^{65}$

A brilhante autora MARIA HELENA DINIZ, ao definir o dano, diz que esse deve ser encarado como uma lesão sofrida por alguém, contra sua vontade, em decorrência de um certo evento:

O dano pode ser definido como a lesão (diminuição ou destruição) que, devido a um certo evento, sofre uma pessoa, contra a sua vontade, em qualquer bem ou interesse jurídico, patrimonial ou moral. ${ }^{66}$

\subsubsection{Nexo Causal}

O nexo causal ou de causalidade é a relação de causa e efeito entre a conduta praticada e o resultado. Antes de ser decidido se o agente agiu ou

\footnotetext{
${ }^{65}$ CAVALIERI FILHO, Sérgio . Op. cit., p. 71

${ }^{66}$ DINIZ, Maria Helena. Op. cit., p. 66.
} 
não com culpa é necessário apurar se ele deu causa ao resultado. Por isso, o nexo causal se revela como o terceiro pressuposto para a configuração da responsabilidade civil.

Assim, para que seja caracterizada a responsabilidade civil do agente, não basta que o mesmo tenha praticado uma conduta ilícita, e nem mesma que a vítima tenha sofrido o dano, sendo imprescindível que o dano tenha sido causado pela conduta ilícita do agente e que exista entre ambos uma necessária relação de causa e efeito. Nesse sentido, o nexo causal é um elemento referencial entre a conduta e o resultado, através do qual se pode concluir quem foi o causador do dano.

O nexo causal se mostra como requisito essencial para qualquer espécie de responsabilidade, diferente do que acontece com a culpa, que não precisa estar presente na responsabilidade objetiva.

Sobre o nexo causal, SÉRGIO CAVALIERI diz que:

\begin{abstract}
Não basta, portanto, que o agente tenha praticado uma conduta ilícita; tampouco que a vitima tenha sofrido um dano. É preciso que esse dano tenha sido causado pela conduta ilícita do agente, que exista entre ambos uma necessária relação de causa e efeito. Em síntese, é necessário que o ato ilícito seja a causa do dano, que o prejuízo sofrido pela vitima seja resultado desse ato, sem o que a responsabilidade não correrá a cargo do autor material do fato. Daí a relevância do chamado nexo causal. Cuida-se, então, de saber quando um determinado resultado é imputável ao agente; que relação deve existir entre o dano e o fato para que este, sob a ótica do Direito, possa ser considerado causa daquele ${ }^{67}$.
\end{abstract}

Diversas teorias surgiram para tentar explicar o nexo de causalidade, dentre essas teorias é importante citar as três principais delas, quais sejam: (i) da causalidade adequada; (ii) teoria dos danos diretos e imediatos e(iv) teoria da equivalência dos antecedentes.

A primeira teoria, ou seja, a teoria da causalidade adequada pode ser encarada como a menos extremada, por pressupor a lógica do razoável. Em breve síntese, a teoria ensina que haverá nexo causal quando, pela ordem natural das coisas, a conduta do agente poderia adequadamente produzir o nexo causal. Assim, a teoria pressupõe o lógico, o natural.

\footnotetext{
${ }^{67}$ CAVALIERI FILHO, Sérgio. Op. cit., p. 49
} 
A segunda teoria, qual seja, a teoria dos danos diretos e imediatos, também denominada como teoria da interrupção do nexo causal, entende que a causa pode ser classificada apenas como o antecedente fático que, ligado por um vínculo de necessariedade ao resultado danoso, determinasse esse ultimo como uma consequência sua, direta e imediata.

Por fim, a teoria da equivalência dos antecedentes, também chamada de teoria da equivalência das condições, ou ainda, conditio sine qua non, considera que toda e qualquer circunstância que tenha concorrido para a produção do dano é considerada como causa para ele.

A maioria da doutrina entende que a teoria da equivalência das condições é a escolhida na esfera penal. Já acerca da teoria adotada na esfera civil, há divergência doutrinária bastante relevante.

Uma parte da doutrina, liderada por Sérgio Cavalieri, Aguiar Dias e Caio Mário, considera a teoria da causalidade adequada como a prevalecente na órbita civil. Segundo essa corrente, embora a literalidade do artigo 403 do Código Civil tenha o condão de induzir ao entendimento de que a teoria adotada pelo ordenamento jurídico brasileiro é a do dano direto e imediato, a prática, por sua vez, demonstra que é prevalecente a aplicação da teoria da causalidade adequada, uma vez que é plenamente possível a responsabilização por danos indiretos

Nesse sentido, em se tratando de responsabilidade civil, CAVALIERI explica que:

Logo, em sede de responsabilidade civil, nem todas as condições que concorrem para o resultado são equivalentes (como no caso da responsabilidade penal), mas somente aquela que foi a mais adequada a produzir concretamente o resultado ${ }^{68}$.

Já outra parte da doutrina, onde se destacam autores como Carlos Roberto Gonçalves, Pablo Stolze Gagliano e Rodolfo Pamplona Filho, defende que a teoria adotada pelo Código Civil Brasileiro é a teoria da causalidade direta ou imediata.

\footnotetext{
${ }^{68}$ CAVALIERI FILHO, Sérgio. Op. cit., p. 52
} 
Os defensores dessa teoria se sustentam no artigo 403 do Código Civil, que estabelece: "ainda que a inexecução resulte de dolo do devedor, as perdas e danos só incluem os prejuízos efetivos e os lucros cessantes por efeito dela direto e imediato, sem prejuízo no disposto na lei processual’.

Carlos Roberto Gonçalves é enfático ao afirmar que:

Das várias teorias sobre o nexo causal, o nosso Código adotou, indiscutivelmente, a do dano direto e imediato, como está expresso no art. 403; e das varias escolas que explicam o dano direto e imediato, a mais autorizada é a que se reporta à consequência necessária ${ }^{69}$

Apesar da divergência doutrinária quanto a teoria adotada pelo Código Civil, é pacífico que a teoria da equivalência das condições, adotada pelo Código Penal Brasileiro, não pode ser a escolhida para a responsabilidade civil, pois acarretaria em uma regressão infinita. Caso essa teoria fosse adotada na órbita civil, seria necessária a indenização de uma eventual vítima de atropelamento não só por quem dirigia o veículo com imprudência, porém também quem lhe vendeu o automóvel, que o fabricou, que forneceu a matéria-prima, etc. ${ }^{70}$

Acerca de tal discussão doutrinária, pertinente se faz citar as brilhantes palavras de RUI STOCO:

Enfim, independente da teoria que se adote, como a questão só se apresenta ao juiz, caberá a este, na análise do caso concreto, sopesar as provas, interpretá-las como conjunto e estabelecer se houve violação do direito alheio, cujo resultado seja danoso, e se existe um nexo causal entre esse comportamento do agente e o dano verificado. ${ }^{71}$

\footnotetext{
${ }^{69}$ GONÇALVES, Carlos Roberto. Direito civil brasileiro. 3. ed. rev. e atual. São Paulo: Saraiva, 2008. v. IV, p. 524

${ }^{70}$ Esse é o entendimento de SÉRGIO CAVALIERI FILHO em Programa de responsabilidade civil. 10 ed. São Paulo: Atlas, 2012, p. 513.

${ }^{71}$ STOCO, Rui. Tratado de responsabilidade civil: doutrina e jurisprudência. 7 ed.. São Paulo Editora Revista dos Tribunais, 2007, p. 152.
} 


\section{Capítulo III - A RESPONSABILIDADE POR ABANDONO AFETIVO}

\subsection{A Intervenção Estatal nas Relações Familiares}

O Estado é legitimo para adentrar no seio familiar a fim de que sejam resguardados e protegido os interesses dos menores que o habitam. $\mathrm{O}$ Estado, através de sua máquina, goza da poder-dever fiscalizar o adimplemento do encargo que recai sobre os responsáveis do menor a fim de que seja garantido a ele todos os seus direitos que lhe são assegurados pela Constituição e pela sua condição de ser humano vulnerável.

É perceptível a intervenção do Estado nas relações paterno-filiais, de início, ao fato de a família ter modificado sua função de ser unidade de direção, passando a tornar-se pluralidade de existências, com que admite uma ingerência na intimidade doméstica, necessária ao processo de politização da família, especialmente em relação ao governo da mesma ${ }^{72}$

Não há de haver confusão entre o dever da família para com a prole e o dever do Estado no controle e fiscalização dessa relação. O Código Civil, em seu artigo $1513^{73}$, retrata que é direito de qualquer pessoa de direito público ou privado interferir na comunhão da vida instituída pela família, cabendo aos pais o controle sobre a família e aos filhos o dever de agir de forma digna e moral.

Nessa esteira, incumbe ao Estado formular e executar a política de atendimento aos direitos da criança e do adolescente, em parceria com a sociedade, fiscalizando a esfera negativa e omissiva da atuação dos pais. $\mathrm{O}$ Estado tem responsabilidade para agir na hipótese de os genitores nãocumprirem o previsto em lei.

O pátrio poder, chamado de poder familiar pelo Código Civil de 2002, passou a receber muito mais ônus do que propriamente conferir

\footnotetext{
${ }^{72}$ COMEL, Denise Damo. Do Poder Familiar. São Paulo: Revista dos Tribunais, 2003. p. 90.

${ }^{73}$ Art. 1.513. É defeso a qualquer pessoa, de direito público ou privado, interferir na comunhão de vida instituída pela família.
} 
poderes para os seus titulares. Fala-se hoje em "pátrio-dever" para designar esse fenômeno que pressupõe uma carga de deveres muito maior do que de $\operatorname{direitos}^{74}$.

O pátrio poder, na acepção moderna, muito distanciada do sentido originário da expressão é um direito-função, um poder-dever, que estaria numa posição intermediaria entre o poder propriamente dito e o direito subjetivo ${ }^{75}$.

Dessa forma, como qualquer dever, o seu descumprimento que gere dano a outrem acarreta em responsabilização do agente causador. Várias são as possibilidades de fiscalização e controle do Estado, seja por meio do poder de polícia, seja por meio do Poder Judiciário, no campo das relações de paternidade.

Sabe-se que o tema é muito polêmico, na medida em que se trata de um ente público intervindo em relações particulares e íntimas. Uma das hipóteses bastante controvertidas foi a chamada "Lei da Palmada", Lei no $13.010 / 2014$

A referida proposição legislativa visa proteger o menor de castigos cruéis e degradantes que eventualmente possam ser submetidos pelos seus pais ou responsáveis. Seu principal fundamento é estabelecer como direito da criança e do adolescente a sua não submissão a qualquer forma de punição corporal, através da adoção de castigos moderados ou imoderados, sob qualquer hipótese, mesmo que os castigos sejam meramente pedagógicos.

Ora, o Estado, ausente no apoio na família e no suporte ao bem-estar do lar, seja na questão estrutural, seja na questão moral, passa a intervir em questão de natureza íntima que se consiste na forma pela qual os pais devem punir as suas crianças e adolescentes.

\footnotetext{
${ }^{74}$ BRANDÃO, Wilson de Andrade. Divórcio e separação judicial. 3 ed. Rio de Janeiro: Freitas Bastos, 1991, p. 157.

${ }^{75}$ Ibid. p. 157-158.
} 
Há quem diga que a Lei da Palmada veio consumar um Estado totalitário e intervencionista, que visa regular todos os tipos de relações interpessoais.

Eis, portanto, a consumação de um Estado totalitário que emerge ao se erigir misticismos, demagogia e oportunismos à condição de Lei, tal como estamos agora assistindo com a famigerada 'Lei da Palmada'.

(...)

O Estado já intervém naquilo que seu filho deve ou não assistir na TV, agora busca intervir na forma de criação deles, sem contudo dar solução ou apresentar alternativas. O seu papel mesmo, qual seja, o de dar acesso à Educação de qualidade nas escolas, esse ele está pouco se lixando...E aí surge a pergunta obrigatória: quem vai intervir no Estado, quando ele espanca a sociedade? ${ }^{76}$

Fato é que aos pais cabe o dever de fornecer a devida assistência material e imaterial a sua prole, a fim de que seja despendida a melhor criação possível para a efetiva contribuição para o bom desenvolvimento da criança e do adolescente.

Portanto, o Poder Público, ao observar as impossibilidades dos pais ao atendimento das necessidades de seus filhos, seja por problemas de desestrutura familiar, seja por desemprego, deverá garantir os direitos fundamentais de crianças e adolescentes, possibilitando-lhes uma vida digna.

A função do Ministério Público é essencial, já que deve observar, a todo momento, os casos de desassistência material ou imaterial, atentando a verdadeira intenção dos genitores e o melhor interesse dos filhos. Cabe ressaltar que se deve distinguir aqueles pais que "podem, mas não exercem o pátrio poder e os que querem, mas não podem exercer o pátrio poder". 77

$\mathrm{O}$ artigo 129 do $\mathrm{ECA}^{78}$ relaciona as medidas pertinentes aos pais ou responsáveis, dentre elas o inciso I, o qual prevê o encaminhamento a

\footnotetext{
${ }^{76}$ ROMEU JUNIOR, Tuma. Lei da palmada: um tapa na cara da família brasileira!. Disponível em $<$ http://www.migalhas.com.br/dePeso/16,MI204630,41046-

Lei+da+Palmada+um+tapa+na+cara+da+familia+brasileira>. Acesso em 4 out. 2015.

${ }^{77}$ SE $\square$ DA, Edson. Construir o passado. São Paulo: Malheiros, 1993, p. 34-35.

${ }^{78}$ Art. 129. São medidas aplicáveis aos pais ou responsável:

I - encaminhamento a programa oficial ou comunitário de proteção à família;

II - inclusão em programa oficial ou comunitário de auxílio, orientação e tratamento a alcoólatras e toxicômanos;

III - encaminhamento a tratamento psicológico ou psiquiátrico;
} 
programa oficial ou comunitário de proteção à família para aqueles pais que não têm condições de proporcionar ao filho uma criação digna por carência material. $^{79}$

Nesse sentido, a atuação do Estado, através de sua máquina, deve ser incisiva a fim de que seja garantido o previsto no art. 227 da Constituição, ou seja, assegurar, por parte do Estado e da Família, o direito à vida, à saúde, à alimentação, à educação, ao lazer, à profissionalização, à cultura, à dignidade, ao respeito, à liberdade e à convivência familiar e comunitária.

É dever da família, da sociedade e do Estado assegurar à criança, ao adolescente e ao jovem, com absoluta prioridade, o direito à vida, à saúde, à alimentação, à educação, ao lazer, à profissionalização, à cultura, à dignidade, ao respeito, à liberdade e à convivência familiar e comunitária, além de colocá-los a salvo de toda forma de negligência, discriminação, exploração, violência, crueldade e opressão.

\section{Nesse sentido, MARLENE SAUER WIECHOREKI dispõe:}

Como educadora, entendo que a responsabilidade do Poder Público envolve a garantia dos direitos fundamentais desde o nascimento com vida, a saber: saúde, alimentação, moradia, educação, o que inclui investimentos em ações de proteção a crianças e adolescentes em situação de risco e que necessitem de atendimento especializado.

(...) Todos eles merecem o nosso olhar, a nossa proteção e uma atitude positiva das autoridades, quer federais, estaduais ou municipais. ${ }^{80}$

Cabe ressaltar que o artigo 227 da Constituição brasileira prevê a que a atuação jurisdicional do Estado se dá por meio do MinistérioPúblico, que

IV - encaminhamento a cursos ou programas de orientação;

V - obrigação de matricular o filho ou pupilo e acompanhar sua frequência e aproveitamento escolar;

VI - obrigação de encaminhar a criança ou adolescente a tratamento especializado; VII advertência;

VIII - perda da guarda;

IX - destituição da tutela;

X - suspensão ou destituição do poder familiar.

Parágrafo único. Na aplicação das medidas previstas nos incisos IX e X deste artigo, observar-se-á o disposto nos arts. 23 e 24.

${ }^{79}$ FERREIRA, Lucia Maria Teixeira. As políticas públicas e o Ministério Público como agentes garantidores do direito à convivência familiar e comunitária de crianças e adolescentes. Revista do advogado, São Paulo, v. 28, n. 101, dez. 2008, p. 65.

${ }^{80}$ WIECHOREKI, Marlene Sauer. Papel da família, da sociedade e do estado na proteção de crianças e adolescentes. Revista Jurídica Consulex, Brasília, v. 12, n. 286, 15 dez. 2008, p. 36. 


\section{é uma instituição delegada que constitui essa função estatal. Como afirma PEDRO LENZA:}

(...) o Ministério Publico é a instituição permanente, essencial à função jurisdicional do Estado, incumbindo-lhe a defesa da ordem jurídica, do regime democrático e dos interesses sociais e individuais indisponíveis. ${ }^{81}$

Ressalta-se que cabe ao Ministério Público atuar em prol dos interesses coletivos e indisponíveis, protegendo o direito de crianças e adolescentes, como acontece nas promotorias da infância e juventude.

Sendo judicial ou administrativa, o poder discricionário conferido ao MinistérioPúblico, com atribuiçõesespecíficas na área da criança e do adolescente, consiste em exercer suas funções sem restrições ou condições impostas, desenvolvidas com empenho e responsabilidade, de forma independente e que vise garantir a efetividade dos direitos constitucionais das crianças e adolescentes $^{82}$

Observa-se que o artigo 201do $\mathrm{ECA}^{83}$ combinando com o artigo 148 do mesmo Estatuto ${ }^{84}$ preveem a responsabilidade do Poder Público perante

\footnotetext{
${ }^{81}$ LENZA, Pedro. Direito constitucional esquematizado. 7. Ed. São Paulo: Método, 2004, p. 345

${ }^{82}$ CHAVES, C; ALVES, L. B. M; ROSENVALD, N. Temas atuais do ministério público: a atuação do "Parquet" nos 20 anos da Constituição Federal. Rio de Janeiro: Lumen Juris, 2010, p. 326.

${ }^{83}$ Art. 201. Compete ao Ministério Público:

(...)

III - promover e acompanhar as ações de alimentos e os procedimentos de suspensão e destituição do pátrio poder, nomeação e remoção de tutores, curadores e guardiães, bem como oficiar em todos os demais procedimentos da competência da Justiça da Infância e da Juventude; (...)

VIII - zelar pelo efetivo respeito aos direitos e garantias legais assegurados às crianças e adolescentes, promovendo as medidas judiciais e extrajudiciais cabíveis; (...)

${ }^{84}$ Art. 148. A Justiça da Infância e da Juventude é competente para:

I - conhecer de representações promovidas pelo Ministério Público, para apuração de ato infracional atribuído a adolescente, aplicando as medidas cabíveis;

II - conceder a remissão, como forma de suspensão ou extinção do processo;

III - conhecer de pedidos de adoção e seus incidentes;

IV - conhecer de ações civis fundadas em interesses individuais, difusos ou coletivos afetos à criança e ao adolescente, observado o disposto no art. 209;

$\mathrm{V}$ - conhecer de ações decorrentes de irregularidades em entidades de atendimento, aplicando as medidas cabíveis;

VI - aplicar penalidades administrativas nos casos de infrações contra norma de proteção à criança ou adolescente;

VII - conhecer de casos encaminhados pelo Conselho Tutelar, aplicando as medidas cabíveis.

Parágrafo único. Quando se tratar de criança ou adolescente nas hipóteses do art. 98, é também competente a Justiça da Infância e da Juventude para o fim de:

a) conhecer de pedidos de guarda e tutela;

b) conhecer de ações de destituição do poder familiar, perda ou modificação da tutela ou guarda;

c) suprir a capacidade ou o consentimento para o casamento;
} 
as crianças e os adolescentes. Esse dever conferido aos Promotores de Justiça da Infância e Juventude, responsáveis pela defesa dessas indivíduos, é elementar e indisponível. Eles nãodetêm a alternativa de agir ou não, quando existe a ameaça ou a violação ao direito, porémtêm a discricionariedade de escolher qual o mecanismo mais eficiente para solucionar o caso, amparado pelos instrumentos que a Constituição Federal de 1988 e o Estatuto da Criança e do Adolescente lhes conferem ${ }^{85}$.

Na hipótese de omissão do núcleo familiar, o Estado, como poder público, não pode ser negligente com tal situação, tendo o dever de responsabilizar e sancionar os pais pelo não cumprimento do poder familiar.

A suspensão, extinção e a destituição do poder familiar se constituem como sanções aplicadas aos pais pela infração dos deveres inerentes ao poder familiar. Ressalta-se que o intuito das sanções não é punitivo, mas protetivo, já que visa preservar o interesse da prole, afastando-a de influências prejudiciais ao seu desenvolvimento.

As sequelas que a perda do poder familiar geram são muito graves e danosas. Por isso, a perda, extinção ou destituição do poder familiar somente deve ser decretada quando sua mantença coloca em perigo a segurança ou a dignidade da prole.

Logo, o poder familiar sujeita-se à fiscalização e ao controle do Estado, nos termos da lei. Sempre que ocorrer algum fato incompatível ao exercício do poder por seus titulares existe a possibilidade de suspensão ou de sua destituição. Tanto a suspensão como a destituiçãosão formas de o Estado proteger a criança ou o adolescente daqueles pais que estão faltando com seus deveres em relação a seus filhos, sempre em prol do interesse do menor. Todavia, a principal diferença entre os institutos de suspensão ou de perda desse poder é a gravidade das faltas cometidas pelos pais ${ }^{86}$.

d) conhecer de pedidos baseados em discordância paterna ou materna, em relação ao exercício do poder familiar;

e) conceder a emancipação, nos termos da lei civil, quando faltarem os pais;

f) designar curador especial em casos de apresentação de queixa ou representação, ou de outros procedimentos judiciais ou extrajudiciais em que haja interesses de criança ou adolescente;

g) conhecer de ações de alimentos;

h) determinar o cancelamento, a retificação e o suprimento dos registros de nascimento e óbito.

${ }^{85}$ CHAVES, C; ALVES, L. B. M; ROSENVALD, N. Op. Cit., p. 327

${ }^{86}$ ZAMBELLI, Sara Koshevnikoff. Intervenc $\square$ ão do Estado no Poder Familiar. Brasília. 2010. 84 p. Monografia de fim de curso - Departamento de Direito do Centro Universitário de Brasília Faculdade de Cie $\square$ ncias Jurídicas e Sociais, p. 54 
Nesse sentido, as medidas impostas aos pais ou responsáveis são proporcionais a gravidade do descumprimento dos deveres impostos a eles.

Dessa forma, percebe-se que o Estado, ora através de regulamentação legislativa, ora através do Poder Judiciário, adentra na relação familiar com o intuito de proteger e salvaguardar os direitos e interesses da criança e do adolescente.

O importante é estabelecer o limite dessa regulamentação estatal, já que a sua omissão importa em graves consequências e ferimento a ordem constitucional enquanto que a regulamentação exagerada importa em dano a intimidade do núcleo familiar, indo, também, de encontro com princípios constitucionais.

Dentre as vantagens da intervenção do Estado no poder familiar, há o impedimento de abuso de direitos pelos pais e a obrigação do cumprimento de seus deveres. O Estado, como ente fiscalizador em busca do bem-estar das crianças e dos adolescentes, irá permitir a concretização do princípio do melhor interesse da criança e do adolescente, na medida em que coibirá a atitudes autoritárias e unilaterais dos pais em relação a seus filhos.

Dentre as desvantagens da intervenção do Estado no seio familiar é a possiblidade dessa intervenção se dar de forma exagerada e descabida, hipótese na qual haverá a lesão a intimidade, a liberdade e a autonomia da vontade dos indivíduos, princípios estruturantes do ordenamento jurídico brasileiro.

Assim, se por um lado a omissão estatal diante de um descumprimento do dever decorrente do poder familiar significa o ferimento da ordem constitucional, a sua intervenção em demasia significa a invasão na intimidade da família e da liberdade de escolha dos pais ou responsáveis.

Nessa esteira, cabe destacar que o descumprimento dos deveres impostos pelo poder familiar acarretarão em responsabilidade do agente causador do dano. Por isso, o presente trabalho, ao tratar do abandono 
afetivo, quer demostrar que tal atitude vai de encontro com os deveres do poder familiar e acarreta em responsabilização do causador.

\subsection{A Espécie de Responsabilidade Civil Aplicável aos Casos de Abandono Afetivo}

Partindo do fundamento de que a afetividade se constitui como um princípio do Direito de Família, derivado do princípio da dignidade da pessoa humana, exprimindo, portanto, valor jurídico, o seu descumprimento gera a responsabilização do agente causador do dano.

Sustenta-se que diante do presumido dano moral e psíquico sofrido em decorrência da ausência ou do desprezo pelo ascendente, os deveres impostos pelo poder familiar não se esgotam no dever de sustento material, englobando, também o dever de afeto.

Desse modo, para aqueles que defendem a possibilidade de responsabilização daqueles que causam o dano decorrente da conduta omissiva ou negativa de fornecer afeto, o fundamento da pretensão é baseada na afetividade como princípio.

PAULO LÔBO diz que "o abandono afetivo nada mais é do que o inadimplemento dos deveres jurídicos de paternidade ${ }^{, 87}$. Assim, o autor estabelece que cabe aos pais, fundado nos princípios da paternidade responsável e da afetividade, prover aos seus filhos menores além da assistência material, a assistência moral. LÔBO ainda afirma que "o poder familiar impõe o dever de companhia aos pais." $" 88$

Nessa esteira, ao fornecer ao afeto valor jurídico, as consequências para o seu descumprimento originam o dano e o dever de repará-lo. Assim, entra-se na seara da responsabilidade civil.

\footnotetext{
${ }^{87}$ LÔBO, Paulo. Direito civil: famílias. 4. ed. São Paulo: Saraiva, 2011. p.288.

${ }^{88}$ Ibid. p. 289.
} 
FLÁVIO TARTUCE ${ }^{89}$ expõe que o principal fundamento para a aplicação do instituto da responsabilidade civil nos casos de abandono afetivoseria o enquadramento da conduta aos termos do art. 186 do Código Civil, que traz positivado o conceito de ato ilícito: "aquele que, por ação ou omissão voluntária, negligência ou imprudência, violar direito e causar dano a outrem, ainda que exclusivamente moral, comete ato ilícito" ${ }^{90}$.

Nessa hipótese, o autor afirma que o direito violado, passível de reparação civil, seria a convivência paterna ou materna, na medida em que o art. 927 do CC prevê que "aquele que, por ato ilícito, causar dano a outrem, fica obrigado a repará-lo".

Por isso, o abandono afetivo configura ato ilícito por ser o afeto um princípio, ou seja, um dever jurídico imposto aos pais frente aos filhos menores. Assim, aquele que descumpre com tal dever, está por descumprir um preceito legal, possibilitando a condenação do infrator à reparação do dano causado.

Outro argumento suscitado para a defesa da possibilidade de se aferir a responsabilização daquele que comete o ato ilícito do abandono afetivo é a ofensa a direitos da personalidade que são inerentes à pessoa humana. Sobre esse enfoque, TARTUCE diz que:

\begin{abstract}
Não restam dúvidas de que tais atribuições são verdadeiros deveres jurídicos que, violados, geram o direito subjetivo a uma indenização pecuniária, muito além do que a simples perda do poder familiar, conforme consta do julgado do Superior Tribunal de Justiça no caso Alexandre Fortes. Pode-se, falar, em reforço, da lesão a um direito da personalidade, nos termos do que dispõe o art. 12, caput, do atual Código Civil, particularmente na lesão à honra e à integridade físico-psíquica ${ }^{91}$
\end{abstract}

Para aqueles que reconhecem a configuração do ato ilícito de abandono afetivo, haverá a possibilidade da ocorrência da conduta ilícita mesmo nos casos em que pais e filhos vivem sob o mesmo teto ou convivem constantemente. Através dessa possibilidade, percebe-se que não

\footnotetext{
${ }^{89}$ TARTUCE, Flávio. Danos Morais por Abandono Moral. Revista Brasileira de Direito das Famílias e Sucessões. Porto Alegre, Magíster; Belo Horizonte: IBDFAM, a. 10, n. 7, p.113, dez./jan. 2009.

${ }^{90}$ Código Civil de 2002, artigo 186.

${ }^{91}$ TARTUCE, Flávio. Op. cit.,p.109
} 
se está buscando a mera convivência, mas a efetiva dedicação, carinho, amor, isto é, enxerga-se o afeto como dever imposto aos pais perante aos filhos menores.

Assim, no que tange ao tema tratado nesse trabalho, destaca-se, acerca das espécies de responsabilidade, a responsabilidade extracontratual, na medida em que inexiste ato unilateral negocial ou contrato moral entre pai e filho. O que existe são direitos e deveres os quais decorrem automaticamente da lei, bem como do simples fato natural de se ter gerado um filho.

A responsabilidade extracontratual, é que incide, portanto, nos casos de abandono moral ou por desamor, tendo em vista que deriva de um dever de conduta, de uma transgressão de comportamento, sendo ainda subjetiva, à medida que nessas relações familiares a discussão da culpa é fundamental.

Como se trata de responsabilidade civil extracontratual subjetiva, seus pressupostos, conforme elencado por CAVALIERI, são: (i) conduta culposa; (ii) nexo causal e (iii) dano.

Diante da necessidade de existência desses pressupostos, argumentos contrários à possibilidade de responsabilização dos pais por abandono afetivo são desenvolvidos.

Se mostra difícil a caracterização da ilicitude da conduta, da culpa e do nexo causal em uma suposta hipótese de abandono afetivo. Primeiramente, questiona-se a ilicitude da conduta. Quando um pai ou mãe apesar de amparar seu filho com alimentos e necessidades materiais, deixa de ampara-lo afetivamente, tal conduta não poderia ser enquadrada como ilícita, na medida não se poderia se impor, mesmo que juridicamente, um sentimento.

Os professores WALSIR RODRIGUES JUNIOR e RENATA ALMEIDA são enfáticos ao afirmar que não se pode impor um sentimento, sobretudo no âmbito familiar.

A entidade familiar deve se encaminhar para a consolidação de uma comunhão plena de vida, embasada em laços de amor. Entretanto, é extremamente provável 
que a imposição desse sentimento não irá cumprir seu papel no seio da família. No lugar de proporcionar união e respeito mútuos, a obrigatoriedade causará discórdia e sentimento de desamparo. A liberdade é pressuposto do afeto ${ }^{92}$.

A Constituição da República, em seu artigo 227, estabeleceu como compromisso da família, comunidade e Estado zelar e primar pelos interesses dos menores proporcionando seu desenvolvimento saudável.

O artigo 1634, inciso I, do Código Civil, prevê que cabe aos pais o dever de sustento, educação e formação moral dos filhos menores. Já no Estatuto da Criança e do Adolescente, está prevista a obrigação dos pais em garantir aos seus filhos a ampla assistência, a interpretando da forma mais abrangente possível. Por fim, o Código Penal, em seu art. $244^{93}$,prevê e reprime a conduta do abandono, bem como o abandono intelectual no artigo $246^{94}$.

Assim, aqueles que defendem a impossibilidade da responsabilização civil dos pais pelo abandono afetivo argumentam que consta expressa na lei a obrigação de sustento material e suporte moral eintelectual dos pais em relação aos filhos, não havendo qualquer obrigação legal ao fornecimento de afeto. Por isso, sustenta-se que não configura ato ilícito a conduta de abandono afetivo.

Por isso, diz-se que ato ilícito passível de reparação é aquele contrário ao direito e como não existiriaprevisão normativa que alcançasseo conteúdo mínimo da obrigação de dar afeto na Constituição Federalou

\footnotetext{
${ }^{92}$ ALMEIDA, Renata Barbosa de; RODRIGUES JÚNIOR, Walsir Edson. Direito Civil: Famílias. Rio de Janeiro: Lumen Juris, 2010, p. 586

${ }^{93}$ Art. 244. Deixar, sem justa causa, de prover a subsistência do cônjuge, ou de filho menor de 18 (dezoito) anos ou inapto para o trabalho, ou de ascendente inválido ou maior de 60 (sessenta) anos, não lhes proporcionando os recursos necessários ou faltando ao pagamento de pensão alimentícia judicialmente acordada, fixada ou majorada; deixar, sem justa causa, de socorrer descendente ou ascendente, gravemente enfermo:

Pena - detenção, de 1 (um) a 4 (quatro) anos e multa, de uma a dez vezes o maior salário mínimo vigente no País.

Parágrafo único - Nas mesmas penas incide quem, sendo solvente, frustra ou ilide, de qualquer modo, inclusive por abandono injustificado de emprego ou função, o pagamento de pensão alimentícia judicialmente acordada, fixada ou majorada

${ }^{94}$ Art. 246. Deixar, sem justa causa, de prover à instrução primária de filho em idade escolar:

Pena - detenção, de quinze dias a um mês, ou multa.
} 
nalegislação infraconstitucional, não haveria como impor a responsabilidade civil por essa conduta.

Um segundo aspecto que serve como justificação para aqueles que defendem a impossibilidade da responsabilização dos pais pelo abandono afetivo é a dificuldade de se caracterizar a culpa na conduta. Ou seja, deduz-se que a conduta daquele que não dá afeto ao filho se configura como uma conduta omissiva e por ser omissiva, para ser considerada causadora de dano, deve ser culposa.

Sustenta-se que é demais subjetiva a configuração da conduta culposa, através da observância da modalidade de negligência. Ora, alegase que a falta de afeto nem sempre se daria por uma conduta culposa, pois é decorrência de diversos fatores externos e íntimos, tornando, assim, temerária a atribuição de culpa exclusiva a alguém por falta de amor.

A professora TAÍSA MARIA MACENA DE LIMA é da corrente da impossibilidade da configuração da responsabilidade civil por abandono moral: "há casos em que o abandono material e intelectual da própria família envolve indistintamente pais e filhos. Todos são vítimas. Não há como apontar um culpado na própria entidade familiar" $" 95$.

Defende-se que inúmeras causas poderiam acarretar no afastamento paterno, com até mesmo o desconhecimento da prole ou ser consequência da conduta daquele que detém a guarda física do menor. Entende-se que, com a demanda, se estaria buscando uma vingança pessoal e não a reparação de um efetivo dano. É o que se percebe através das palavras do Min. Fernando Gonçalves do STJ:

(...) é preciso levar em conta que, muitas vezes, aquele que fica com a guarda isolada da criança transfere a ela os sentimentos de ódio e vingança nutridos contra o ex-companheiro, sem olvidar ainda a questão de que a indenização pode

\footnotetext{
${ }^{95}$ LIMA, Taisa Maria Macena de. Responsabilidade civil dos pais por negligência na educação e formação escolar dos filhos: o dever dos pais de indenizar o filho prejudicado. In: PEREIRA, Rodrigo da Cunha (Coord.). Afeto, ética, família e o novo Código Civil. Belo Horizonte: Del Rey, 2004, p. 629.
} 
não atender exatamente o sofrimento do menor, mas também a ambição financeira daquele que foi preterido no relacionamento amoroso ${ }^{96}$.

O terceiro aspecto que é alvo de crítica é quanto ao nexo causal entre a conduta do pai ou mãe que nega o afeto e o dano causado ao filho. Mesmo que se admita em tese o abalo psíquico, o nexo de causalidade entre a conduta do ofensor e o dano mostrar-se-ia de improvável e difícil constatação, uma vez que diversos outros fatores poderiam ter contribuído para a origem e a construção do dano.

Infere-se, portanto, que prova do nexo de causalidade entre a conduta do suposto ofensor no caso do abandono afetivo parental e o alegado dano, na maioria das vezes, será controvertida, pois não haverá certeza da real causa do abalo psíquico $^{97}$.

Nessa esteira, para aqueles que defendem a impossibilidade da responsabilização por abandono afetivo, o afeto se mostra como um valor moral, como um sentimento que não pode ser imposto, devendo ser espontâneo. Assim, questionam tamanha ingerência estatal na relação familiar e encaram negativa a patrimonialização do afeto.

Como pode ser observado, há argumentos favoráveis e desfavoráveis a responsabilização daqueles que praticam o abandono afetivo. Parece mais razoável, porém, o entendimento pela possibilidade de aplicação do instituto da responsabilidade civil ao casos de abandono afetivo. Não é atoa que grande parte da doutrina e da jurisprudência vem entendendo pelo seu cabimento.

\footnotetext{
${ }^{96}$ STJ, 4 a Turma, Resp. 757.411 - MG (2005/0085464-3), Rel. Min. Fernando Gonçalves. Jul. 29 nov. 2005. Disponível em <www.stj.jus.br>. Acesso em 10 out. 2015.

${ }^{97}$ VIEGAS, Cláudia Mara de Almeida Rabelo; POLI, Leonardo Macedo. Os Efeitos do Abandono Afetivo e a Mediação Como Forma de Solução de Conflitos Paterno-Filiais. Disponível em $<$ http://www.ambito-juridico.com.br/site/?n_link=revista_artigos_leitura\&artigo_id=12913>. Acesso em 06 out. 2015.
} 


\subsection{O Alcance da Responsabilidade Civil nas Relações do Abandono Afetivo pela Parentalidade: da Perda do Poder Familiar à Indenização Pecuniária}

Algo que é bastante controverso na doutrina é o alcance da responsabilidade civil nas relações do abandono afetivo. Há quem entenda que a única consequência possível é a perda ou a suspensão do poder familiar enquanto que outros entendem que além dessas, a indenização pecuniária é plenamente possível.

Assim, doutrinariamente, alguns defendem a possibilidade de indenização por abandono afetivo e os que são desfavoráveis a tal aplicação.Aqueles que são contra a possiblidade de indenização, sustentam que a partir de uma interpretação teleológica da expressão "abandono", prevista no artigo 1638, II, do Código Civil, se faz crer que ausência total de afeto dos pais em relação aos filhos menores daria ensejo apenas a destituição do poder familiar, se mostrando incabível o arbitramento de uma indenização pecuniária. Tal entendimento foi muito sustentado até o recente julgamento do STJ. Esse entendimento pela impossibilidade da indenização por danos morais leva em consideração o princípio do melhor interesse da criança e do adolescente, bem como a impossibilidade de se impor um sentimento a outrem.

Para aqueles que defendem apenas a destituição do poder familiar, inexiste no ordenamento jurídico o dever de reparar a prole pela falta de assistência afetiva, isto é, pelos danos morais eventualmente sofridos. $\mathrm{Na}$ hipótese de arbitramento de indenização pecuniária por abandono afetivo, o juiz estaria impondo uma verdadeira pena civil a uma conduta não tipificada no sistema normativo, afrontando os princípios democrático e da separação dos poderes, previsto no artigos $1^{\circ}$, caput, e $2^{\circ}$ da Constituição Federal $^{98}$.

\footnotetext{
${ }^{98}$ Art. $1^{\circ}$ A República Federativa do Brasil, formada pela união indissolúvel dos Estados e Municípios e do Distrito Federal, constitui-se em Estado Democrático de Direito e tem como fundamentos:
} 
Por outro lado, há aqueles que defendem a possiblidade do arbitramento de indenização nas relações de abandono afetivo. MARIA BERENICE DIAS, como já citada, é favorável a referida indenização:

\begin{abstract}
Comprovado que a falta de convívio pode gerar danos, a ponto de comprometer o desenvolvimento pleno e saudável do filho, a omissão do pai gera dano afetivo susceptível de ser indenizado. (...)A lei obriga e responsabiliza os pais no que toca ao cuidado com os filhos. A ausência desses cuidados, o abandono moral, viola a integridade psicofísica dos filhos, bem como o princípio da solidariedade familiar, valores protegidos constitucionalmente ${ }^{99}$
\end{abstract}

Da mesma forma, GAGLIANO e PAMPLONA, se posicionam favorável a indenização, alegando que a mesma obtém caráter punitivo e pedagógico. Defendem que somente a perda do poder familiar caracterizaria como um favor para o genitor que realiza a conduta omissiva:

Mas é preciso se compreender que a fixação dessa indenização tem um acentuado e necessário caráter punitivo e pedagógico, na perspectiva da função social da responsabilidade civil, para que não se consagre o paradoxo de se impor ao pai ou mãe responsável por esse grave comportamento danoso (jurídico e espiritual), simplesmente, a 'perda do poder familiar', pois, se assim o for, para o genitor que o realiza, essa suposta sansão repercutiria como um verdadeiro favor. ${ }^{100}$

Desse modo, há duas posições contraditórias sobre a possiblidade do arbitramento de indenização para as relações de abandono afetivo. Existindo aqueles que defendem o seu cabimento e aqueles que o rechaçam.

Sabe-se que há argumentos fortes que fundamentam ambos os posicionamentos, a doutrina, porém, é majoritária na defesa da possibilidade do arbitramento de indenização para aqueles que sofreram danos decorrentes do abandono afetivo.

Além da doutrina, parece que o caminho que vem sendo seguido é no sentido da possiblidade do arbitramento de indenização pelos danos morais

\footnotetext{
Art. $2^{\circ}$ São Poderes da União, independentes e harmônicos entre si, o Legislativo, o Executivo e o Judiciário.

${ }^{99}$ DIAS, Maria Berenice. Manual de Direito das Famílias. $8^{\mathrm{a}}$ Edição. Revista, atualizada e ampliada. São Paulo: Editora Revista dos Tribunais, 2011, p. 416.

${ }^{100}$ GAGLIANO, Pablo Stolze; PAMPLONA FILHO, Rodolfo. Novo Curso de Direito Civil - Vol. VI - Direito de Família. $1^{\text {a }}$ ed. Rio de janeiro: Saraiva, 2011, p. 736.
} 
decorrentes do abandono afetivo. Tanto é assim que o Poder Judiciário e o Poder Legislativo caminham para a consolidação desse entendimento.

\subsubsection{Indenização Cível: a Resposta do Poder Judiciário}

No que concerne ao entendimento jurisprudencial sobre a possibilidade ou não de indenização em decorrência do abandono afetivo, esse se mostra bastante conflitante. Cabe trazer decisões que sustentam tanto a impossibilidade quanto a possibilidade dos danos morais.

O Superior Tribunal de Justiça vinha entendendo que embora presentes todos os requisitos para que ensejasse a responsabilidade civil, não seria cabível a indenização, na medida em que a omissão causada pelo genitor não constituía ato ilícito.

Tal entendimento pode ser visto através da decisão do REsp 757.411/MG, de relatoria doministro Fernando Gonçalves, datada de 29 de novembro de 2005, onde foi a primeira oportunidade na qual o STJ se manifestou sobre o tema:

RESPONSABILIDADE CIVIL. ABANDONO MORAL. REPARAÇÃO. DANOS MORAIS. IMPOSSIBILIDADE. 1. A indenização por dano moral pressupõe a prática de ato ilícito, não rendendo ensejo à aplicabilidade da norma do art. 159 do Código Civil de 1916 o abandono afetivo, incapaz de reparação pecuniária. 2. Recurso especial conhecido e provido. [Grifou-se $]^{101}$

Tal decisão sufragou a tese de ser incabível a indenização por abandono afetivo. $\mathrm{O}$ voto se sustentou em dois pilares: (a) a destituição do poder familiar é a consequência jurídica do abandono e do descumprimento dos deveres de sustento, guarda e educação, como previsto pelo artigo 24 do Estatuto da Criança e Adolescente e artigo 1.638, inciso II, do Código Civil, não sendo cabível a compensação pecuniária pela conduta de

\footnotetext{
${ }^{101}$ STJ, $4{ }^{\mathrm{a}}$ Turma, REsp 757411/MG, Relator: Ministro Fernando Gonçalves, Data de Julgamento: 29/11/2005. Disponível em <http://www.stj.jus.br/>. Acesso em 09 out. 2015.
} 
desafetoe (b) a condenação ao pagamento de indenização colaboraria para o afastamento de qualquer chance de aproximação entre pai e filho.

Essa tese foi reafirmada em 2009, através do julgamento do REsp 514.350/SP, relatado pelo ministro Aldir Passarinho Junior, em 28 de abril de 2009:

CIVIL E PROCESSUAL. AÇÃO DE INVESTIGAÇÃO DE PATERNIDADE. E CONHECIMENTO. DANOS MORAIS REJEITADOS. ATO ILÍCITO NÃO CONFIGURADO. Firmou o Superior Tribunal de Justiça que "A indenização por dano moral pressupõe a prática de ato ilícito, não rendendo ensejo à aplicabilidade da norma do art. 159 do Código Civil de 1916 o abandono afetivo, incapaz de reparação pecuniária. Recurso especial não conhecido.[Grifou-se] ${ }^{102}$

Assim, diante do existente entendimento do STJ, os Tribunais de Justiça de Santa Catarina e do Rio Grande do Sul também se manifestavam em sentido contrário a possibilidade de indenização nos casos de abandono afetivo.

No Tribunal da Justiça de Santa Catarina o entendimento majoritário é de que a indenização em decorrência de danos morais é incabível. O Desembargador Jorge Luis da Costa Bebe, se manifestou pela impossibilidade dos danos morais, por acredita que se estaria favorecendo o desenvolvimento de uma afetividade compulsória, já que os pais se viriam em uma posição obrigatória de dar afeto e amor mesmo que não possuíssem. Veja-se:

APELAÇÃO CÍVEL. RESPONSABILIDADE CIVIL. AÇÃO DE INDENIZAÇÃO POR DANOS MORAIS. FILHO QUE IMPUTA AO PAI O COMETIMENTO DE ABANDONO MORAL E AFETIVO, CULPANDO-LHE PELO DISTANCIAMENTO DE AMBOS AO LONGO DA VIDA E PELOS SOFRIMENTOS EXPERIMENTADOS EM VIRTUDE DISTO. AGRAVO RETIDO. INTEMPESTIVIDADE. NÃO INTERPOSIÇÃO IMEDIATA, NA PRÓPRIA AUDIÊNCIA DE INSTRUÇÃO E JULGAMENTO. ART. 523, $\S 4^{\circ}$, DO CPC. MÉRITO. AO PODER JUDICIÁRIO NÃO É DADA A INCUMBENNCIA DE TUTELAR O AMOR OU O DESAFETO, NUMA ESPÉCIE DE JURISDICIONALIZAÇÃO DOS SENTIMENTOS, QUE SÃO INCONTROLÁVEIS PELA SUA PRÓPRIA ESSÊNCIA. A AFEIÇÃO

\footnotetext{
${ }^{102}$ STJ, $4{ }^{\text {a }}$ Turma, REsp 514.350/SP, Rel. Ministro Aldir Passarinho Junior, julgado em 28/04/2009, DJe 25/05/2009. Disponível em <http://www.stj.jus.br/>. Acesso em 09 out. 2015.
} 
COMPULSÓRIA, FORJADA PELO RECEIO DA RESPONSABILIZAÇÃO PECUNIÁRIA, É TÃO OU MAIS FUNESTA DO QUE A PRÓPRIA AUSÊNCIA DE AFETO. RESPONSABILIZAR, MEDIANTE INDENIZAÇÃO PECUNÁRIA A AUSÊNCIA DE SENTIMENTOS, É INCENTIVAR A INSINCERIDADE DO AMOR, CONSPIRANDO PARA O NASCIMENTO DE RELAÇÕES FAMILIARES ASSENTADAS SOB OS PILARES DO FINGIMENTO, O QUE NÃO SE COADUNA COM A MORAL, A ÉTICA E O DIREITO. ATO ILÍCITO NÃO CARACTERIZADO. INEXISTÊNCIA DA OBRIGAÇÃO DE INDENIZAR. ARTS. 186 E 927 DO CC E ART. 333, INC. I, DO CPC. PRECEDENTES DESTA CORTE E DO STJ. APELO DESPROVIDO. Amor existe ou não existe e, em não existindo, pode até vir a ser cultivado com atitudes de aproximação, jamais sob ameaça de punição. A construção de laços afetivos mediante coação pecuniária é de todo temerária, ressumbrando bizarro imaginar pais que não nutrem afeto algum pela prole, fingirem, de um instante para outro, aquilo que são incapazes de sentir genuinamente, apenas pelo temor de virem a ser condenados a indenizar o que desditosamente já está consumado. Quantos filhos seriam obrigados a compartilhar a presença nociva de alguns pais por força dessa imposição jurisdicional? Guarda alguma razoabilidade imaginar benefícios para o filho quando sua relação com o pai é construída sobre alicerces falsos? Quanto de humanidade realmente restaria de um afeto legalmente conduzido? Em muitos casos, seria ainda de indagar: quantos filhos seriam efetivamente beneficiados pela monetarização do afeto? Para o pai ausente, cujo coração não aflorou para o amor aos filhos, a punição maior está nos dramas da sua própria consciência. É preciso, todavia, saber distinguir a ausência de afeição com a repugnância acintosa. Por isso, em casos excepcionais, onde a falta de afeto criou espaço para um sentimento de desprezo acintoso, de menoscabamento explícito, público e constrangedor, o filho possa pleitear a reparação pelo dano anímico experimentado, porque nesse caso, ao invés da inexistência de amor, não nascido espontaneamente, há uma vontade deliberada e consciente de repugnar a prole não desejada. ${ }^{103}$

Do mesmo modo, coloca-se o Desembargador Marcus Tulio

Sartorato, que alega não estarem presentes os requisitos ensejadores da fixação de indenização:

DIREITO CIVIL. AÇÃO DE INVESTIGAÇÃO DE PATERNIDADE C/C INDENIZAÇÃO POR DANOS MORAIS. ALEGADO ABANDONO MATERIAL E AFETIVO PELO GENITOR. RECONHECIMENTO DA PATERNIDADE REALIZADO APENAS MEDIANTE O AJUIZAMENTO DA PRESENTE AÇÃO JUDICIAL. REQUISITOS DO ART. 186 DO CÓDIGO CIVIL NÃO CONFIGURADOS. DEVER DE INDENIZAR INEXISTENTE. SENTENÇA MANTIDA. RECURSO DESPROVIDO. Os sentimentos compreendem a esfera mais íntima do ser humano e, para existirem, dependem de uma série de circunstâncias subjetivas. Portanto, o filho não pode obrigar o pai a nutrir amor e carinho por ele, e por este mesmo motivo, não há fundamento para reparação pecuniária por abandono afetivo. ${ }^{104}$

\footnotetext{
${ }^{103}$ TJSC, Apelação Cível n. 2011.073787-1, de São José, rel. Des. Jorge Luis Costa Beber, j. 0208-2012. Disponível em <http://www.stj.jus.br/>. Acesso em 09 out. 2015.

${ }^{104}$ TJSC, Apelação Cível n. 2012.005438-5, de Joinville, rel. Des. Marcus Tulio Sartorato, j. $27-$ 03-2012. Disponível em <http://www.stj.jus.br/>. Acesso em 09 out. 2015.
} 
O Tribunal de Justiça do Rio Grande do Sul também tem sua jurisprudência majoritária desfavorável a indenização por abandono afetivo. O desembargador Luiz Felipe Brasil Santos entendeu não ser cabível a aplicação da indenização por danos morais gerados pelo abandono afetivo, considerando que não se pressupõe o abandono como ato ilícito. Observase:

\begin{abstract}
APELAÇÃO CÍVEL. INDENIZAÇÃO POR DANO MORAL AOS FILHOS.ABANDONO AFETIVO. No direito de família, o dano moral é, em tese, cabível. No entanto, imprescindível que haja a configuração do ato ilícito. O distanciamento do varão em relação aos filhos não constitui motivo para fundamentar a indenização por dano moral, sendo tal fato um acontecimento bastante recorrente, um fato da vida, apesar de lamentável. Embora seja plausível que os apelantes tenham sofrido pela ausência do pai, essa situação não pode ser atribuída ao genitor somente, a ponto de levar à obrigação de indenizar. Ademais, em que pese reprovável, a conduta do demandado não se enquadra no conceito jurídico de ato ilícito, que gera o dever de indenizar. NEGARAM PROVIMENTO. UNÂNIME. ${ }^{105}$
\end{abstract}

O desembargador Alzir Felippe Schmitz também entendeu, em 2013, não cabível a indenização em relação ao abandono afetivo, considerando que o ato de abandono afetivo não ser considerado ilícito. Veja-se:

\begin{abstract}
APELAÇÃO CÍVEL. AÇÃO INDENIZATÓRIA DECORRENTE DE ABANDONO AFETIVO. INOCORRÊNCIA. A responsabilidade civil no Direito de Família é subjetiva, de modo que o dever de indenizar pressupõe o ato ilícito e nexo de causalidade. Nesse passo, não se pode reconhecer como ato ilícito o alegado abandono afetivo que, por sua vez, não guarda nexo de causalidade com os danos alegadamente sofridos pelo autor. APELO NÃO PROVIDO. ${ }^{106}$
\end{abstract}

Em 2012, entretanto, apesar de prevalecer perante os Tribunais analisados e ser até então o entendimento do Superior Tribunal de Justiça pela impossibilidade dos danos morais nos casos de abandono afetivo, esse último tribunal entendeu de forma divergente. A desembargadora Nancy

\footnotetext{
${ }^{105}$ TJRS, Apelação Cível No 70044172401, Oitava Câmara Cível, Relator: Luiz Felipe Brasil Santos, Julgado em 13/10/2011. Disponível em <http://www.stj.jus.br/>. Acesso em 09 out. 2015. ${ }^{106}$ TJRS, Apelação Cível No 70052059417, Oitava Câmara Cível, Relator: Alzir Felippe Schmitz, Julgado em 07/02/2013. Disponível em <http://www.stj.jus.br/>. Acesso em 09 out. 2015.
} 
Andrighi, em seu voto, sustenta que o ato de deixar de cuidar da família implica no reconhecimento da ilicitude, ponderando se tratar de uma conduta omissiva, permitindo-se, assim, a indenização ao ofendido. Confere-se apenas a ementa do julgado, que será no item 3.4 bem discutido:

CIVIL E PROCESSUAL CIVIL. FAMÍLIA. ABANDONO AFETIVO. COMPENSAÇÃO POR DANO MORAL. POSSIBILIDADE. 1. Inexistem restrições legais à aplicação das regras concernentes à responsabilidade civil e o consequente dever de indenizar/compensar no Direito de Família. 2. O cuidado como valor jurídico objetivo está incorporado no ordenamento jurídico brasileiro não com essa expressão, mas com locuções e termos que manifestam suas diversas desinências, como se observa do art. 227 da $\mathrm{CF} / 88$. 3. Comprovar que a imposição legal de cuidar da prole foi descumprida implica em se reconhecer a ocorrência de ilicitude civil, sob a forma de omissão. Isso porque o non facere, que atinge um bem juridicamente tutelado, leia-se, o necessário dever de criação, educação e companhia - de cuidado - importa em vulneração da imposição legal, exsurgindo, daí, a possibilidade de se pleitear compensação por danos morais por abandono psicológico. 4. Apesar das inúmeras hipóteses que minimizam a possibilidade de pleno cuidado de um dos genitores em relação à sua prole, existe um núcleo mínimo de cuidados parentais que, para além do mero cumprimento da lei, garantam aos filhos, ao menos quanto à afetividade, condiç̃̃es para uma adequada formação psicológica e inserção social. 5. A caracterização do abandono afetivo, a existência de excludentes ou, ainda, fatores atenuantes - por demandarem revolvimento de matéria fática - não podem ser objeto de reavaliação na estreita via do recurso especial. 6. A alteração do valor fixado a título de compensação por danos morais é possível, em recurso especial, nas hipóteses em que a quantia estipulada pelo Tribunal de origem revela-se irrisória ou exagerada. 7. Recurso especial parcialmente provido. $[\text { Grifou-se }]^{107}$

Ante ao exposto, apesar de se ponderar que é majoritário o entendimento jurisprudencial pela impossibilidade de cabimento da indenização por danos morais nas relações de abandono afetivo, conclui-se ser cabível a referida indenização diante das transformações da sociedade, bem como através da nova interpretação conferida pelo Superior Tribunal de Justiça.

Da mesma forma entende o Instituto Brasileiro de Direito de Família (IBDFAM) ao aprovar dois enunciados - Enunciado $\mathbf{n}^{\mathbf{0}} 8$ e Enunciado $\mathbf{n}^{\mathbf{0}}$ 10 - prevendo a possibilidade de arbitramento de danos morais nas relações de abandono afetivo.

\footnotetext{
${ }^{107}$ STJ, $3{ }^{\text {a }}$ Turma, REsp 1159242/SP, Rel. Ministra Nancy Andrighi, julgado em 24/04/2012, DJe 10/05/2012. Disponível em <http://www.stj.jus.br/>. Acesso em 09 out. 2015.
} 
Os Enunciados se revelam como uma diretriz para a criação da nova doutrina e jurisprudência em Direito de Família, na medida em que o ordenamento jurídico brasileiro é deficiente quanto ao tema.

O conteúdo dos Enunciados aprovados pelo Instituto está previsto no Estatuto das Famílias (Projeto de Lei $\left.n^{\circ} 470 / 2013\right)^{108}$, mas por trataram temas em que a sociedade não pode esperar, se mostrou necessária a aprovação de tais diretrizes.

Segundo os especialistas:

Essas questões são tão importantes que não dá para esperar a aprovação do Estatuto das Famílias. Por isso estamos nos antecipando. São Enunciados principiológicos para esse novo Direito de Família. Esses são os temas palpitantes que ainda não encontram regras e que ainda são alvo de dúvidas ${ }^{109}$

Os Enunciados contemplam temas inovadores e polêmicos. A concepção de família alterou com o tempo, mas a lei não acompanhou estas mudanças.

O Direito de Família não pode continuar repetindo a história das injustiças e condenando à invisibilidade arranjos de família que não estão previsto nas leis.

(...)

os Enunciados são para aqueles aspectos da vida das famílias que não tem uma regra específica. Seja porque são questões novas, seja porque a tramitação legislativa é lenta, dando uma referência e um norte para um novo Direito de Família brasileiro. ${ }^{110}$

Assim, como o tema do abandono afetivo se revela como sendo relevante e polêmico, foram aprovados dois Enunciados. O Enunciado $\mathrm{n}^{\mathrm{o}} 8$ foi aprovado no ano de 2013 e o Enunciado ${ }^{\circ} 10$ foi aprovado em 2015. Recentes, pois, ambas as diretrizes.

\footnotetext{
${ }^{108}$ Projeto de Lei $\mathrm{n}^{\circ}$ 470/2013. Disponível em <http://www.migalhas.com.br/arquivos/2014/1/art20140109-13.pdf>. Acesso em 08 out. 2015. ${ }^{109}$ Informação retirada do site oficial do IBDFAM. Disponível em <http://www.ibdfam.org.br/noticias/5194/Enunciados\%20do\%20IBDFAM\%20são\%20aprovados >. Acesso em 03 nov. 2015.

${ }^{110}$ Entrevista como Rodrigo da Cunha Pereira, presidente do IBDFAM. Disponível em: <http://www.ibdfam.org.br/noticias/5194/Enunciados\%20do\%20IBDFAM\%20são\%20aprovados >. Acesso em 03 nov. 2015.
} 
Enunciado 8. $\underline{\mathbf{O} \text { abandono afetivo pode gerar direito à reparacão pelo dano }}$ causado.

Enunciado 10. $\underline{\text { É cabível o reconhecimento do abandono afetivo em relação }}$ aos ascendentes idosos.

Desse modo, os Enunciados acima mencionados se mostram como uma tendência da doutrina e da jurisprudência do Direito de Família, prevendo a pacificação do entendimento pela possiblidade do arbitramento de danos morais pelo abandono afetivo. Mais além, pelos Enunciados se percebe a tendência de ampliação do instituto, permitindo o reconhecimento do abandono afetivo em relação aos ascendentes idosos.

Torna-se, assim, imperioso ao Estado efetuar a aplicação da indenização pelos danos morais sofridos, afim de que seja dirimido novos casos, permitindo aos filhos o seupleno e saudável desenvolvimento, além de coibir que sofram com o abandono. Assim, revela-se o arbitramento de indenização por danos morais pelo Poder Judiciário como uma resposta a conduta contrária ao Direito, já que a sociedade altera de forma muito constante e rápida e não há legislação que acompanhe tal ritmo, vislumbrando a tendência da jurisprudência e os Enunciados já aprovados pelo IBDFAM.

\subsubsection{Punição Criminal: Tentativa Louvável de Esforço pelo Poder Legislativo}

Apesar da sociedade mudar de forma muito constante e dinâmica e ser difícil o seu acompanhamento pela Legislação, o drama do abandono afetivo passou a não se restringir apenas ao Poder Judiciário.

Por ser considerado como um problema de ordem pública, muitos juristas passaram a questionar o seu tratamento pela legislação.

\footnotetext{
${ }^{111}$ Enunciados obtidos no site oficial do IBDFAM. Disponível em: $<$ http://www.ibdfam.org.br/noticias/5819/IBDFAM+aprova+Enunciados+++>. Acesso em 03 nov. 2015.
} 
Segundo esta orientação de cunho positivista, os princípios constitucionais da dignidade, da afetividade, do dever de convivência e da paternidade responsável, ainda que acolhidos pelo Código Civil e pelo ECA, por si só não seriam suficientes à efetivação da convivência entre pais e filhos. Seria necessária a previsão expressa do ato ilícito e as penalidade aplicáveis em caso de sua ocorrência, visando impedir novas condutas lesivas ${ }^{112}$

Como exemplo, RODRIGO DA CUNHA PEREIRA considera que mesmo que tenha havido esforços estatais para coibir o abandono afetivo, a inexistência de previsão de pena é rechaçado pelo autor:

Por isso a necessidade de responsabilização dos pais pelo não cuidado e, principalmente, pelo abandono dos filhos. $\mathrm{O}$ caráter punitivo e preventivo, aliados a uma necessidade pedagógica da reparação civil, significam um freio a tal ato danoso àquele que não escolheu nascer. ${ }^{113}$

Nessa esteira de entendimento, dois projetos de lei foram criados a fim de que fosse punida e reparados os danos pelo abandono afetivo.

O primeiro, o Projeto de Lei do Senado $n^{0} 700 / 2007114$, prevê não somente a responsabilização, como também a criminalização com pena privativa de liberdade dos pais que deixarem de prestar assistência moral aos filhos menores de 18 anos.

Crivella foi o Senador responsável pela propositura do projeto, sendo de sua autoria. Para ele, decisões do Poder Judiciário que condenam os pais pelo abandono afetivo não são suficientes para coibir essa prática, já que decisões em sentido contrária permaneciam sendo proferidas.

O Projeto de Lei $n^{\circ} 700 / 2007$ ainda tramita e, no dia 09 de setembro do presente ano, a Comissão de Direitos Humanos aprovou a mudança no

\footnotetext{
${ }^{112}$ BRAGA, Julio Cezar de Oliveira. Abandono afetivo: do Direito à Psicanálise. Rio de Janeiro: Lumen Juris, 2014. p, 47.

${ }^{113}$ PEREIRA, Rodrigo da Cunha. Responsabilidade civil por abandono afetivo. Disponível em $<$ http://www.rkladvocacia.com/arquivos/artigos/art_srt_arquivo20131029210851.pdf>. Acesso em 14 out. 2015.

${ }^{114}$ Projeto de Lei $\mathrm{n}^{\mathrm{o}}$ 700/2007. Disponível em <http://www.migalhas.com.br/arquivo_artigo/art20100222-04.pdf> . Acesso em 12 out. 2015.
} 
Estatuto da Criança e do Adolescente. Em 06 de outubro, o Projeto de Lei foi remetido à Câmara dos Deputados.

Na hipótese dele ser aprovado, os $\S \S 2^{\circ}$ e $3^{\circ}$, do art. $4^{\circ}$ do ECA, passarão a ter a seguinte redação:

Art. $4^{\circ}$. (...). $\S 2^{\circ}$. Compete aos pais, além de zelar pelos direitos de que trata o art. $3^{\circ}$ desta Lei, prestar aos filhos assistência moral, seja por convívio, seja por visitação periódica, que permitam o acompanhamento da formação psicológica, moral e social da pessoa em desenvolvimento.

$3^{\circ}$. Para efeitos desta Lei, compreende-se por assistência moral devida aos filhos menores de dezoito anos:

I - a orientação quanto às principais escolhas e oportunidades profissionais, educacionais e culturais;

II - a solidariedade e apoio nos momentos de intenso sofrimento ou dificuldade;

III - a presença física espontaneamente solicitada pela criança ou adolescente e possível de ser atendida.

Além dessas mudanças, ainda haverá a alteração do parágrafo único do art. $5^{\circ}$ do ECA, que passará a vigorar com a seguinte redação:

Art. $5^{\circ}$. (...). Parágrafo único. Considera-se conduta ilícita, sujeita a reparação de danos, sem prejuízo de outras sanções cabíveis, a ação ou a omissão que ofenda direito fundamental de criança ou adolescente previsto nesta Lei, incluindo os casos de abandono moral.

O crime de abandono afetivo, por sua vez, será disciplinado pelo artigo 232-A, do ECA. Veja-se:

Art. 232-A. Deixar, sem justa causa, de prestar assistência moral ao filho menor de dezoito anos, nos termos dos $\S \S 2^{\circ}$ e $3^{\circ}$ do art. $4^{\circ}$ desta Lei, prejudicando-lhe o desenvolvimento psicológico e social.

Pena - detenção, de um a seis meses

Ressalta-se que ao ser submetido à Comissão de Constituição, Justiça e Cidadania (CCJC), foi vetada a expressão "abandono moral", restando sugerido o termo "abandono afetivo", para designar a deficiente convivência da criança ou do adolescente com seu genitor. Além disso, a Comissão entendeu exagerada a responsabilização penal dos pais abandônicos, entendendo que a competente indenização no âmbito civil bastaria. 
Já o segundo Projeto de Lei é o PL no 4.294-A/2008 ${ }^{115}$, aprovado em 13 de abril de 2011 por unanimidade pela Comissão de Seguridade Social da Família da Câmara Federal. O referido Projeto acaba por responsabilizar também o filho que priva os pais da dedicação afetiva.

Ao justificar a finalidade de seu projeto de lei, o deputado Carlos Bezerra sustenta que o envolvimento familiar não pode ser pautado apenas por um parâmetro patrimonialista e individualista. Segundo o deputado:

No caso dos filhos menores, o trauma decorrente do abandono afetivo parental implica marcas profundas no comportamento da criança. A espera por alguém que nunca telefona - sequer nas datas mais importantes - o sentimento de rejeição e a revolta causada pela indiferença alheia provocam prejuízos profundos em sua personalidade. ${ }^{116}$

O projeto aguarda votação na Comissão de Constituição, Justiça e Cidadania (CCJC) da câmara, já tendo sido aprovado na Comissão de Seguridade Social e Família (CSSF).

Além desses dois projetos de leis supramencionados, o abandono afetivo passou também a receber tratamento específico no Projeto de Lei $n^{\circ}$ 470/2013 ${ }^{117}$, denominado de Estatuto das Famílias, ainda em trâmite no Parlamento.

O Estatuto foi pensado e elaborado pela comunidade jurídica do Instituto Brasileiro de Direito de Família (IBDFAM), havendo entre seus membros, os mais respeitados juristas. Paternidade socioafetiva, alienação parental, abandono afetivo, famílias recompostas e auto curatela são alguns dos temas mais relevantes que foram previstos pela proposição.

Sobre o abandono afetivo, o texto do projeto prevê para a sua prática, assim como para a prática de alienação parental, punições a fim de proteger e incentivar as relações estáveis e saudáveis entre pais e filhos.

\footnotetext{
${ }^{115}$ Projeto de Lei $\quad \mathrm{n}^{\mathrm{o}}$ 4.294-A/2008. Disponível em $<\mathrm{http}: / /$ www.camara.gov.br/proposicoesWeb/prop_mostrarintegra? codteor $=864558 \&$ filename $=\mathrm{Av}$ ulso+-PL+4294/2008>. Acesso em 15 out. 2015.

${ }^{116}$ Justificativa de voto do Dep. Carlos Bezerra. Disponível em $<\mathrm{http}: / /$ www.camara.gov.br/proposicoesWeb/prop_mostrarintegra?codteor $=864558 \&$ filename $=\mathrm{Av}$ ulso+-PL+4294/2008>. Acesso em 15 out. 2015.

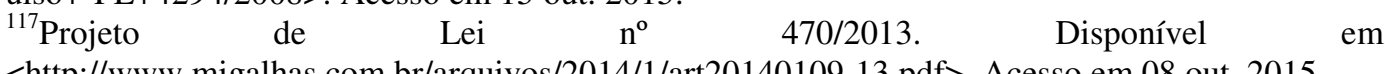
<http://www.migalhas.com.br/arquivos/2014/1/art20140109-13.pdf>. Acesso em 08 out. 2015.
} 
A proposição legislativa, ao prever que pais e filhos têm direitos e deveres recíprocos de convivência familiar, aponta o sentido para a futura discussão acerca do abandono afetivo e da alienação parental. O caminho a ser seguido é claro: proibição e combate a tais condutas. Tal combate se ampara no comando de que os filhos não podem ser privados do contato regular com ambos os pais, mesmo que os pais já tenham constituído outras famílias.

A SENDORA LÍDICE DA MATA, ao justificar a elaboração da proposição normativa, prevê que "para o Direito, o afeto não se traduz apenas como um sentimento, mas principalmente como dever de cuidado, atenção, educação, entre outros" $" 118$.

Sobre a alienação parental, o Estatuto das Famílias a define como a tentativa do pai ou da mãe, dos avós ou de outra pessoa que tenha a criança ou o adolescente sob sua autoridade, convivência ou vigilância de afastá-lo de um dos pais. Além disso, o texto normativo, ao listar sinais dessa prática, indica a criação de dificuldades para o contato de um dos pais com o filho; a mudança do domicílio para local distante; a apresentação de falsa denúncia ou desqualificar sua conduta, inclusive em processos judiciais e, sem justificativa, a dificultação da convivência familiar.

Segundo o Projeto de Lei $\mathrm{n}^{\circ}$ 470/2013, o indício de alienação parental pode acarretar na abertura de processo judicial com tramitação mais acelerada. Na hipótese de confirmação da conduta, o magistrado terá a prerrogativa de adotar determinadas providências, que deverão ser escolhidas de acordo com a gravidade do caso. São elas: (i) advertir a mãe ou o pai alienador, que pode ser punido, ainda, com o pagamento de multa; (ii) alterar o regime de convivência familiar em favor do genitor alienado e (iii) declarar a suspensão da autoridade parental.

O abandono afetivo, ponto central do presente trabalho, é também considerado como conduta ilícita pelo Estatuto das Famílias. A proposta

\footnotetext{
${ }^{118}$ Informação obtida pelo site oficial do Senado Federal. Disponível em $<$ http://www12.senado.gov.br/jornal/edicoes/2014/11/06/texto-pune-alienacao-parental-eabandono-afetivo/imprimir_materia_jornal>. Acesso em 09 out. 2015.
} 
legislativa conceitua a prática do abandono afetivo como qualquer ação ou omissão que ofenda direito fundamental da criança ou do adolescente, entre eles a convivência familiar saudável.

Assim, além de prezar pelos direitos estabelecidos na legislação de proteção à criança e ao adolescente, através do ECA, o Estatuto prevê expressamente a competência dos pais em prestar assistência afetiva aos filhos, classificando como dever o afeto a ser fornecido a prole.

O texto classifica como dever de afeto a orientação quanto às principais escolhas e oportunidades profissionais, educacionais e culturais; a solidariedade e o apoio nos momentos de necessidade ou dificuldade; e o cuidado, a responsabilização e o envolvimento com o filho ${ }^{119}$.

Nesse sentido, a conduta do abandono afetivo é expressamente punida pelo Estatuto das Famílias - Projeto de Lei nº470/2013 - a considerando como conduta contrária ao direito, ou seja, conduta ilícita. Desse modo, quando o projeto se tornar lei vigente, acabará a discussão quanto a licitude ou a ilicitude da conduta.

Nessa esteira, esboça-se o esforço do Poder Legislativo em se ver punida a conduta de abandono afetivo, na medida em que essa se revela contrária a todos os preceitos legais do ordenamento jurídico, bem como a todos os preceitos morais do ser humano.

Por isso, considerando-se a conduta de abandono afetivo como conduta ilícita passível de punição, o arbitramento de indenização pelos danos morais decorrentes dessa conduta se mostra consequência lógica e necessária.

\footnotetext{
${ }^{119}$ FRANCO, Simone. Alienação parental e abandono afetivo são punidos por estatuto. Disponível em <http://www12.senado.leg.br/noticias/materias/2014/10/23/alienacao-parental-eabandono-afetivo-sao-punidos-por-estatuto >. Acesso em 07 out. 2015.
} 


\subsection{Comentários ao REsp. 11.59242/SP que Reconheceu a Procedência do Pedido de Indenização por Abandono Afetivo}

Em 2012, quando julgado o Recurso Especial $n^{\circ} 11.59242 / \mathrm{SP}$, a Terceira Turma do STJ entendeu pela possibilidadede ensejo do dever de reparação pelos danos morais sofridos nas relações de abandono afetivo.

Através da leitura do acórdão do julgamento do REsp, percebe-se que: (i) foi reconhecida a aplicação da responsabilidade civil e o consequente dever de indenização no Direito de Família; (ii) foi reconhecido o dever de cuidado como valor jurídico objetivo, incorporando no ordenamento jurídico brasileiro através do art. 227 da CRFB; (iii) foi reconhecido que se descumprida a imposição legal de cuidar da prole haverá a ocorrência de ilicitude civil, sob a forma de omissão, exsurgindo a possibilidade de se pleitear a compensação por danos morais por abandono psicológico e (iv) foi reconhecida a existência de um núcleo mínimo de cuidados parentais em relação à sua prole a fim de que sejam garantidas condições para uma adequada formação psicológica e inserção social por via da afetividade.

A ministra Nancy Andrighi, ministra relatora, protagonizou um dos mais brilhantes votos já proferidos no STJ. Em seu voto, a Ministra, brilhantemente, inicia através da afirmação de que inexistem restrições legais à aplicação das regras relativas à responsabilidade civil e o consequente dever de indenizar/compensar no Direito de Família.

Posteriormente, pontua o interessante ponto de que a perda do poder familiar, como previsto no art. 1.638, II do CC, não suprime ou afasta a possibilidade do arbitramento de indenizações ou compensações, já que essa punição visa apenas a proteção do menor e não a compensação de prejuízos advindos do malcuidado recebido pela prole. Veja-se:

Nota-se, contudo, que a perda do pátrio poder não suprime, nem afasta, a possibilidade de indenizações ou compensações, porque tem como objetivo primário resguardar a integridade do menor, ofertando-lhe, por outros meios, a 
criação e educação negada pelos genitores, e nunca compensar os prejuízos advindos do malcuidado recebido pelos filhos. [Grifou-se] $]^{120}$

Após, a ministra relatora passa a descrever os elementos necessários para a caracterização do dano moral, enunciando a tríade que configura a responsabilidade civil subjetiva: (i) o dano; (ii) a culpa do autor e (iii) o nexo causal. Ela afirma que apesar de ser bastante conhecida essa lição do Direito, ela passa a se tornar complexa quando aplicada às relações familiares, já que essas são pautadas por fatores de alto grau de subjetividade, como a afetividade, o amor, a mágoa, que dificultam identificar os elementos configuradores do dano moral.

No entanto, a Min. afirma que apesar da dificuldade, é possível se vislumbrar nas relações entre pais e filhos o liame objetivo e subjacente, ou seja, obrigações mínimas inerentes ao poder familiar que são previstos tanto na Constituição como nas leis infraconstitucionais.

Por isso, ela sustenta que é inquestionável que o dever de assistência psicológica seja uma das obrigações do poder familiar, o chamando como obrigação inescapável. Ela afirma, contudo, que apesar de ser inquestionável o dever de assistência psicológica, a viabilidade técnica de se responsabilizar civilmente àqueles que descumprem essa incumbência se mostra como algo polêmico.

Para esclarecer a possibilidade técnica de responsabilizar todos aqueles que infringirem o dever de assistência psicológica a Min. defende a ilicitude da conduta e a existência da culpa. Para melhor explicar, a ministra sustenta que ao encarar o cuidado como valor jurídico, o seu descumprimento através de uma conduta omissiva implica em descumprimento de preceito legal.

A Min. afirma que “(...) amar é faculdade, cuidar é dever” e sustenta que não se trata de amar, mas sim "(...) a imposição biológica e legal de cuidar, que é dever jurídico, corolário da liberdade das pessoas de

\footnotetext{
${ }^{120}$ STJ, $3^{\text {a }}$ Turma, REsp 1159242/SP, Rel. Ministra Nancy Andrighi, julgado em 24/04/2012, DJe 10/05/2012. Disponível em <http://www.stj.jus.br/>. Acesso em 13 out. 2015.
} 
gerarem ou adotarem filhos ${ }^{121}$ "Por consequência e através desse entendimento, a comprovação do descumprimento da imposição legal implica, por certo, a ocorrência de ilicitude civil, sob a forma de omissão.

Além da ilicitude, se fixa o ponto da existência de culpa, ou seja, apesar de serem inúmeras as hipóteses que poderiam justificar a ausência de pleno cuidado de um dos genitores em relação à sua prole, deve-se considerar negligente a conduta que vai de encontro ao dever objetivo de cuidado.

Por fim, a Ministra Nancy Adrighi ainda verifica a necessidade de ocorrência do dano e do nexo causal para que seja possível o arbitramento de indenização por dano moral em caso de abandono afetivo.

Para verificar a existência de ambos os elementos, a Min. afirma que basta a existência de laudo formulado por especialista que aponte a existência de uma determinada doença psicológica e a vincule ao descuido por parte de um dos pais. Assim, a conduta negligente deve ser causadora de um dano, havendo portanto, nexo causal.

Quanto ao valor da compensação por danos morais, o voto se deu no sentido de que o grau das agressões ao dever de cuidado deve ser proporcional ao valor arbitrado pelo juízo.

O ministro-vogal, Dr. Massami Uyeda, por sua vez, votou no sentido contrário, ou seja, entendendo pela impossibilidade de fixação de danos morais em casos de abandono afetivo. Para sustentar seu entendimento, o Min. afirma que isso faria com que se potencializassem as mágoas sofridas, alegando que ao abrir essa porta, não haveria mais tranquilidade nas famílias.

\footnotetext{
Ora, se atentarmos para a realidade dos fatos, qualquer filho, qualquer filha, enfim, qualquer pessoa poderá dizer assim: mas estou sendo preterido em relação aos meus irmãos e qualquer dado subjetivo poderia motivar um pedido de indenização por dano moral. Ora, isso faria com que quantificássemos ou potencializássemos as mágoas íntimas - muitas legítimas, algumas supostamente legítimas - de filhos, de irmãos, de pais, de marido e mulher

${ }^{121}$ STJ, $3^{\text {a }}$ Turma, REsp 1159242/SP, Rel. Ministra Nancy Andrighi, julgado em 24/04/2012, DJe 10/05/2012. Disponível em <http://www.stj.jus.br/>. Acesso em 13 out. 2015.
} 
também,porque o dever dos cônjuges está entre prestar assistência, amar e tal. E os estudos indicam que esse amor é uma coisa da convivência.

(...)

Estou dizendo a tese. Se abrirmos essa tese aqui, olha, como diria o pessoal, sai de baixo. Este Tribunal irá cuidar de mágoas [Grifou-se] ${ }^{122}$

O terceiro a votar foi o Min. Sidnei Beneti que acabou por reconhecer a responsabilidade civil e ressaltar a necessidade da proporcionalidade entre o valor arbitrado a título de danos morais e a responsabilidade do pai. In verbis:

A responsabilidade pelo dano moral deve, contudo, ser proporcional à ação ou omissão do agente em sua provocação, determinando, essa proporcionalidade, o pagamento, por ele, de indenização proporcional, e reservando ao lesado a busca de indenização de outrem, na medida da proporcionalidade deste na causação do dano ${ }^{123}$

Após o Sr. Min. Paulo de Tarso Sansverino pediu vista para melhor exame da matéria em discussão e acompanhou o voto do Min. Sidnei Beneti. O Min. Paulo de Tarso Sanseverino sustentou em seu voto que a responsabilidade civil no Direito de Família não pode ser equiparada à responsabilidade civil extracontratual em geral, entendo o reconhecimento de dano moral em matéria de família como sendo situação excepcionalíssima. O voto-vista do Ministro Paulo Sanseverino ressalta que "apenas o abandono completo e notório do filho tem o condão de gerar a responsabilidade civil dos pais", alega que o "dever de cuidado, pois, apresenta cum conteúdo inegavelmente subjetivo" e, ainda, esclarece que "o abandono afetivo apenas ocorre quando o progenitor descumpre totalmente seu dever de cuidado, infringindo flagrantemente as mais comezinhas obrigações para com seu filho"124.

\footnotetext{
${ }^{122}$ STJ, $3^{\text {a }}$ Turma, REsp 1159242/SP, Rel. Ministra Nancy Andrighi, julgado em 24/04/2012, DJe 10/05/2012. Disponível em <http://www.stj.jus.br/>. Acesso em 13 out. 2015.

${ }^{123}$ STJ, $3^{\text {a }}$ Turma, REsp 1159242/SP, Rel. Ministra Nancy Andrighi, julgado em 24/04/2012, DJe 10/05/2012. Disponível em <http://www.stj.jus.br/>. Acesso em 13 out. 2015.

${ }^{124}$ STJ, $3^{\mathrm{a}}$ Turma, REsp 1159242/SP, Rel. Ministra Nancy Andrighi, julgado em 24/04/2012, DJe 10/05/2012. Disponível em <http://www.stj.jus.br/>. Acesso em 13 out. 2015.
} 
Prosseguindo no julgamento, após o voto-vista do Sr. Ministro Paulo de Tarso Sanseverino, a retificação de voto da Sra. Ministra Nancy Andrighi e a ratificação de voto-vencido do Sr. Ministro Massami Uyeda, a Turma, por maioria, deu parcial provimento ao recurso especial nos termos do voto da Sra. Ministra Relatora. Votou vencido o Sr. Ministro Massami Uyeda. Os Srs. Ministros Sidnei Beneti, Paulo de Tarso Sanseverino e Ricardo Villas Bôas Cueva votaram com a Sra. Ministra Relatora. [Grifou-se]

Posteriormente essa polêmica decisão do REsp, foram opostos Embargos de Divergência. Desse modo, na tarde do dia 09 de abril de 2014, o Superior Tribunal Justiça, através do julgamento dos embargos, teve a oportunidade de definir se o abandono afetivo efetivamente enseja o dever de reparação por dano moral. Os embargos tiveram como Desembargador Relator o Ministro Marco Buzzi, integrante da Segunda Seção, órgão que reúne as Turmas de Direito Privado da Corte.

À época, o Ministro Luis Felipe Salomão publicou um artigo sustentando que o STJ passaria a ter a oportunidade de uniformizar o seu entendimento acerca do tema através do julgamento dos referidos embargos.

O Superior Tribunal de Justiça terá a inédita oportunidade de uniformizar o entendimento acerca do tema por ocasião do julgamento dos EREsp 1.159.242/SP, de relatoria do eminente ministro Marco Buzzi, previsto para esta quarta-feira (9/4), na $2^{\mathrm{a}}$ Seção - Direito Privado.

A primeira vez em que a corte deliberou sobre o tema foi no julgamento do REsp 757.411/MG, relatado pelo ministro Fernando Gonçalves. O caso foi julgado pela $4^{\mathrm{a}}$ Turma, no dia 29 de novembro de 2005, tendo aquele Colegiado, por maioria de votos, sufragado a tese de ser incabível a indenização por abandono afetivo.

(...)

Essa tese foi reafirmada por ocasião do julgamento do REsp 514.350/SP, relatado pelo ministro Aldir Passarinho Junior, na $4^{\text {a }}$ Turma, em 28 de abril de 2009.

Porém, no primeiro semestre de 2012, a $3^{\text {a }}$ Turma abraçou entendimento contrário, tendo sido acolhida a possibilidade de indenização do abandono afetivo (REsp 1.159.242/SP, relatado pela ministra Nancy Andrighi, $3^{\mathrm{a}}$ Turma, julgado em 24 de abril de 2012) [Grifou-se] ${ }^{125}$.

\footnotetext{
${ }^{125}$ SALOMÃO, Luis Felipe. Momento propício: STJ vai uniformizar jurisprudência sobre abandono afetivo. Disponível em: <http://www.conjur.com.br/2014-abr-08/luis-felipe-salomaostjuniformizar-entendimento-abandono-efetivo>. Acesso em 09 out. 2015.
} 
Contudo, mesmo diante da oportunidade fornecida pelo julgamento dos Embargos de Divergência, o mérito da questão deixou de ser enfrentado e a jurisprudência não foi uniformizada, na medida em quea Segunda Seção acolheu a preliminar de não conhecimento dos Embargos de Divergência.

A decisão considerou que a Terceira Turma decidiu pela possiblidade dos danos morais em caso excepcional e que, por isso, a decisão não poderia servir de parâmetro para os embargos de divergência.

Fato é que não se mostra coerente ou razoável impor aos pais o amor, o carinho e a ligação existencial inerentes à relação de pais e filhos, contudo, a responsabilidade parental impõe aos pais o dever de cuidado, dever este cujo descumprimento poderá ensejar o dever de reparação.

Como assinala VALÉRIA SILVA GALDINO CARDIN, realmente, o afeto não é algo que pode ser monetizado, porém, a sua falta acarreta inúmeros danos psicológicos a uma criança ou adolescente, que se sente rejeitado, humilhado perante os outros amigos em que os pais são presentes. $^{126}$

É comprovado que uma criança ou adolescente que sofreu o abandono afetivo terá dificuldades em se relacionar no futuro. Logo, a indenização tem o condão de proporcionar que esta pessoa recebesse auxílio psicológico para tratar das sequelas oriundas da falta de visitação, do descaso, da não orientação ética, moral e intelectual etc.

É sabido que a personalidade necessita do afeto para o seu desenvolvimento. Sem o afeto a criança não sobreviverá ou, no mínimo, não se humanizará. Tal preceito foi bem explanado na decisão da $2^{\mathrm{a}}$ Vara de Família no caso paradigma do menino Sean Goldman:

\footnotetext{
A personalidade, para o seu desenvolvimento, necessita do afeto e do amor, sem os quais efetivamente não sobrevivemos. $\mathrm{O}$ amor não é uma qualidade instintiva, depende de aprendizagem, de pautas relacionais, da convivência e dos exemplos que fazem sua inscrição o psiquismo, de forma consciente e inconsciente. Se a criança não tiver quem a cuide com amor, certamente não sobreviverá ou, no mínimo, não se humanizará. $O$ amor é condição para entender o outro e a
}

\footnotetext{
${ }^{126}$ CARDIN, Valéria Silva Galdino. Dano moral no Direito de Família. São Paulo: Saraiva, 2012, p. 161.
} 
si, respeitar dignidade, desenvolver uma personalidade saudável. Assim, é na interação com o outro, inicialmente na família, por meio do amor, que se desenvolve, na personalidade, as qualidades eminentemente humanas, de pensamento, de auto reflexão e empatia. [Grifou-se] ${ }^{127}$

Por isso, não há que ser rechaçada a possiblidade de compensação por danos morais no caso de um pai abandonar afetivamente seu filho. Como visto, o afeto é a base para todo o bom desenvolvimento da personalidade, sendo responsável pela sobrevivência ou humanização do indivíduo.

Pela gravidade do assunto, esperemos que o assunto volte em breve a ser analisado pelo STJ para que, assim, obtenhamos uma posição definitiva acerca desse controvertido tema.

\subsection{Mediação como Modo Mais Efetivo para a Solução do Conflito}

A mediação é uma relevante técnica de solução consensual de conflitos que objetiva a facilitação do diálogo entre os mediados, para que, por si só, alcancem uma solução de benefício mútuo e sustentável no tempo.

O termo "mediação" origina-se do latim mediare, que significa intervir, mediar.A mediação se consiste em um meio não-jurisdicional de solução de litígios, onde se preza a comunicação das partes e o seu protagonismo.

LÍLIA MAIA DE MORAIS SALES conceitua a mediação como:

Mediação é um procedimento consensual de solução de conflitos por meio do qual uma terceira pessoal imparcial - escolhida ou aceita pelas partes - age no sentido de encorajar e facilitar a resolução de uma divergência. As pessoas envolvidas nesse conflito são as responsáveis pela decisão que melhor satisfaça. A mediação representa um mecanismo de solução de conflitos utilizado pelas próprias partes que, motivadas pelo diálogo, encontram uma alternativa ponderada, eficaz e satisfatória. O mediador é a pessoa que auxilia na construção desse diálogo. ${ }^{128}$

\footnotetext{
${ }^{127}$ Decisão da $2^{\mathrm{a}}$ Vara de Família no âmbito da ação de reconhecimento de paternidade socioafetiva combinada com guarda e posse do menor Sean.

${ }^{128}$ SALES, Lília Maia de Morais. Mediação de Conflitos: Família, Escola e Comunidade. Florianópolis: Conceito Editorial, 2007.
} 
Os elementos básicos para se iniciar um processo de mediação podem ser numerados como: (i) existência de partes em conflito; (ii) existência de contraposição de interesses e (iii) existência de um terceiro neutro capacitado a facilitar a busca pelo acordo. É nesse sentido que NURIA BELLOSO MARTÍN afirma que a mediação se caracteriza pelos seguintes elementos:

a) voluntariedade; b) eleição do mediador; c) aspecto privado; d) cooperação entre as partes; e) conhecimentos específicos (habilidade) do mediador; f) reuniões programadas pelas partes; g) informalidade; h) acordo mútuo; i) ausência de sentimento de vitória ou derrota. ${ }^{129}$

A mediação busca primeiramente o diálogo entre as partes e o consequente acordo entre elas através de um processo no qual questões subjetivas e objetivas hão de ser discutidas.

Como é possível perceber, a comunicação é a base nuclear do processo de mediação. Nesse sentido, Águida Arruda Barbosa informa:

(...) na França, toda a construção teórica da mediação vem fundamentada em Habermas, filósofo contemporâneo, cuja contribuição filosófica é que tudo se constrói pela comunicação, pela necessidade do diálogo, pela humanidade; enfim, pela ética da discussão. ${ }^{130}$

O discurso e a participação dos mediados são os elementos que permitem a adoção de mecanismos de pacificação dos conflitos, priorizando a autonomia da vontade e a liberdade das partes. Ao vislumbrar a medição a partir desse prisma, é possível afirmar que o processo se mostra muito mais participativo e dialógico do que a jurisdição.

A sentença judicial, apesar de colocar um fim a lide no plano jurídico, muitas vezes não resolve as questões subjetivas e não é capaz de reestabelecer a comunicação das partes envolvidas, permanecendo o

\footnotetext{
${ }^{129}$ MARTín, Nuria Belosso. Reflexiones sobre Mediación Familiar: Algunas Experiencias en el Derecho Comparado. Revista Eletrônica de Direito Processual. $2^{\mathrm{a}}$ ed . Disponível em: $<$ www.revistaprocessual.com>. Acesso em 05 out. 2015.

${ }^{130}$ BARBOSA, Águida Arruda. Prática da mediação: ética profissional. In: Família e dignidade humana. Anais do V Congresso Brasileiro de Direito de Família. Coordenador: Rodrigo da Cunha Pereira. 2006, p.63.
} 
conflito existente no mundo dos fatos. Nesse sentido, através da decisão judicial, se instaura um cenário ganha-perde, onde há uma parte vencedora e outra vencida, mesmo que ambas estejam certas de serem detentoras de um direito subjetivo.

Através do processo de mediação, a solução do conflito é criada e encontrada pelas partes, tendo o mediador a função de apenas auxilia-las no alcance de tal solução. Ressalta-se o fato de que não cabe ao mediador apontar ou de qualquer forma pressionar alguma forma de solução para o conflito, cabendo às partes, por elas mesmo, chegar ao alcance da mesma.

SAMANTHA PELAJO e EVANDRO SOUZA E LIMA ${ }^{131}$ dizem que o conflito em si tem um potencial transformador que é capaz de aprimorar a qualidade da interação e, consequentemente, estreitamento de vínculos.

Ambos, ao citarem MORTON DEUTSCH ${ }^{132}$, afirmam que os desentendimentos não são necessariamente destrutivos. Sustentam que a proposta é aproveitar o momento de crise para reavaliar a qualidade da interação entre as partes e os reais interesses e necessidades próprios e recíprocos. Os autores afirmam que a forma pela qual se leva o conflito é o que irá determinar o resultado final da controvérsia:

o que verdadeiramente determina o resultado da controvérsia é a forma como se administra o momento de crise. (...) a proposta é aproveitar a crise para reavaliar a qualidade de interação e o mérito das necessidades e interesses recíprocos. Essa dinâmica construtiva faz com que as soluções negociadas com base na empatia, na atitude colaborativa e na exploração criativa de alternativas potencializem os ganhos e minimizem os custos, isto é, não raro, cada uma das partes tem necessidades e interesses plenamente atendidos, sem fazer excessivo esforço. [Grifou-se] ${ }^{133}$

\footnotetext{
${ }^{131}$ LIMA, Evandro Souza e; PELAJO, Samantha. A mediação nas ações de família. In:. ALMEIDA, D. A. R.; PANTOJA, F. M.; PELAJO, S. (Coords.). A mediação no novo Código de Processo Civil. Rio de Janeiro: Forense, 2015. p. 239.

${ }^{132}$ DEUTSCH, Morton. The resolution of conflict: constructive and destructive processes. New Haven: Yale University Press, 1973 apud ALMEIDA, D. A. R.; PANTOJA, F. M.; PELAJO, S. (Coords.). A mediação no novo Código de Processo Civil. Rio de Janeiro: Forense, 2015, p. 239.

${ }^{133}$ LIMA, Evandro Souza e; PELAJO, Samantha. Op. cit. p. 239.
} 
Quando se trata de conflitos familiares, nada mais claro de que a relação entre as partes é continuada e questões subjetivas e problemas na comunicação estão sempre permeando tais conflitos. Dessa forma, quando esse tipo de conflito é levado ao Poder Judiciário, através de lides a serem julgadas por um Juízo, o fracasso no alcance da solução ideal é quase sempre certo.

Nesse sentido, entende-se que pelas particularidades dos conflitos familiares, o Poder Judiciário não se mostra o melhor caminho para a solução de tais conflitos, já que se mostra como um meio adversarial, onde há muito pouco espaço para o diálogo. É pacífico na doutrina que a jurisdição tradicional não é capaz de trazer respostas suficientes para os conflitos familiares.

Nessa esteira, tem-se a mediação como a forma alternativa mais adequada para a solução de conflitos das relações familiares, na medida que busca a preservação dos vínculos relacionais e da discussão não apenas das questões objetivas, mas das subjetivas. Na maioria das vezes, as decisões judiciais não são capazes de alcançar a pacificação social, pois os julgadores são sujeitos presos a critérios objetivos, previamente estabelecidos na lei. Além disso, os julgadores não são capazes de compreender a diferença entre a posição e o interesse das partes, isto é, não conseguem alcançar o verdadeiro interesse das partes através da simples leitura de petições.

Por isso, através da jurisdição tradicional, resolve-se aquela lide judicial, mas o real conflito persiste, pois a pauta de questões subjetivas não foi discutida e a comunicação entre as partes não foi restabelecida.

Sobre o tema da ineficácia da jurisdição nos conflitos familiares, sobretudo sobre o abandono afetivo, no mês de dezembro de 2004, a Revista Época ${ }^{134}$ publicou uma interessante reportagem que trazia as três

\footnotetext{
${ }^{134}$ RUBIN, Débora; TEIXEIRA, Paulo César. Pelo direito de ser filho. Revista Época, Rio de Janeiro, 6 de dez. 2004, p. 60-62.
} 
ações judiciais que tinham por objeto a responsabilização de um dos pais pelo abandono afetivo, propostas até a referida época no Brasil.

Comprovou-se que em nenhum dos três casos concretos houve aproximação entre pai e filho após decisão favorável aos filhos. Assim, a reportagem dizia que as decisões se mostraram ineficientes, já que os filhos, se realmente buscavam o amor paterno, continuarão a ter em suas vidas o abandono que ensejou a ação.

Um dos filhos que figura como autor na ação judicial afirma que sua pretensão ao ingressar perante o Poder Judiciário teria sido chamar a atenção do pai e que mesmo sendo procedente seu pedido não desejava receber o dinheiro correspondente à indenização.

Aqui há o claro conflito tão estudado pela Mediação entre posições e interesses. Resta claro que a posição adotada pelo filho no processo judicial se mostrava adversarial e mascarado por questões intimamente subjetivas, enquanto que seus reais interesses em nada estavam sendo explicitados naquela demanda.

Ora, por esse relato, se questiona se o Poder Judiciário seria via adequada para responder os anseios desse filho. Indaga-se ainda se o Poder Judiciário, meio coercitivo e pouco flexível, seria o caminho mais efetivo para a resolução de pendências de foro tão íntimo e subjetivo.

Além disso, questiona-se a eficácia do arbitramento de indenização quando esse não é o realmentequerido para o autor da ação.

Em relação ao nexo de causalidade, questiona-se se o Poder Judiciário seria capaz de avaliar e afirmar que a conduta do genitor ou da genitora causou o dano psicológico ao filho. Estabelecer com tanta lógica uma relação de causa e consequência é querer aplicar raciocínio físico ao amor.

Assim, como dado estatístico, de fevereiro de 2002 a agosto de 2003, 453 casos foram enviados para a mediação. Desse total, 393 referiam-se a conflitos de ordem familiar. O estudo apontou que dos 453 processos, dos quais $86 \%$ eram de ordem familiar, 365 apresentaram resultado positivo e 
88 resultaram em tentativas frustradas. Nesse sentido, em média, $80 \%$ dos conflitos enviados para o processo de mediação obtiveram um resultado favorável. Através desse dado, se confirma a teoria de a mediação deve ser encarada como meio mais eficaz e adequado de solução de conflitos familiares, como no caso de abandono afetivo. ${ }^{135}$

Tanto é que o Novo Código de Processo Civil prevê o artigo $695^{136}$ que traz a mediação como ato inerente e obrigatório ao procedimento nas ações de família, determinando a citação do réu para o comparecimento à audiência de mediação e conciliação logo após o recebimento da petição inicial.

Essa compulsoriedade nada mais é que a expertise do legislador primário ao observar o cenário social, onde é possível se perceber que, mundialmente, há o índice de $90 \%{ }^{137}$ de acordos obtidos no curso de processos judiciais relacionados a temas familiares.

Há quem diga que tal obrigatoriedade seria uma afronta ao princípio da autonomia da vontade, mas inexiste razão para tal entendimento, na medida em que uma vez escolhida a intervenção estatal, cabe aos jurisdicionados observar o procedimento previsto pelo legislador. Cabe, ainda, ao Estado incentivar o uso de instrumentos especiais e eficazes para a solução dos conflitos de interesses. Além disso, a obrigatoriedade prevista na nova legislação apenas alcança a participação na mediação, não atingindo a negociação propriamente dita, ou seja, não são obrigadas as partes a negocias e alcançar um acordo, mas apenas a comparecer a uma primeira reunião onde se irá explicar, de forma preliminar, a proposta da

\footnotetext{
${ }^{135}$ SALES, Lilia Maia de Morais. Conflitos Familiares - A Mediação como Instrumento Consensual de Solução. Disponível em <http://gajop.org.br/justicacidada/wpcontent/uploads/Conflitos-Familiares---A-Mediacao-Como-Instrumento.pdf>. Acesso em 06 out. 2015.

${ }^{136}$ Art. 695. Recebida a petição inicial e, se for o caso, tomadas as providências referentes à tutela provisória, o juiz ordenará a citação do réu para comparecer à audiência de mediação e conciliação, observado o disposto no art. 694.

${ }^{137}$ Informação dada pela professora Pauline Tesler no seminário sobre Práticas Colaborativas, realizado no Rio de Janeiro nos dias 10 a 13 de abril de 2014. Informação obtida no no livro LIMA, Evandro Souza e; PELAJO, Samantha. A mediação nas ações de família. In: ALMEIDA, D. A. R.; PANTOJA, F. M.; PELAJO, S. (Coords.). A mediação no novo Código de Processo Civil. Rio de Janeiro: Forense, 2015, p. 235.
} 
mediação, fornecendo a oportunidade das partes de vivenciarem ou não a experiência do processo de diálogo e negociação assistida.

Assim, o legislador caminha para o sentido das práticas colaborativas e dos modos alternativos de solução de conflito, prevendo ênfase no processo de mediação, sobretudo nas ações de família, onde ele se mostra e extrema eficiência e prevê especificidades. 


\subsection{O Interesse da Psicanálise para o Direito: Uma Visão Interdisciplinar}

"O Direito é um discurso do homem sobre si, assim como a Psicanálise" afirma DERRIDA. ${ }^{138}$

Para conceituar o Direito, NORBERTO BOBBIO o define

brilhantemente como sendo:

O conjunto de normas de conduta e de organização, constituindo uma unidade e tendo por conteúdo a regulamentação das relações fundamentais para a convivência e sobrevivência do grupo social, tais como as relações familiares, relações econômicas, as relações superiores de poder, e ainda a regulamentação dos modos e formas através das quais o grupo social reage à violação das normas. ${ }^{139}$

A Psicanálise, por sua vez, é método de investigação teórica da psicologia, desenvolvido por Sigmund Freud que se propõe à compreensão e a análise do homem, compreendido como sujeito do inconsciente. Isto é, a Psicanálise é a ciência que estuda o comportamento e os processos mentais dos indivíduos.

Atualmente, é crescente a discussão sobre a interlocução dos temas jurídico e psicanalítico. Os operadores do Direito, cada vez mais, tem se interessado em realizar um trabalho interdisciplinar que amplie o campo de estudo, já que fazer valer a ordem jurídica se mostra um trabalho cada vez mais complexo.

O Direito para proteger a dignidade da pessoa humana, elevada a princípio fundamental da República na Constituição Federal Brasileira de 1988 (BRASIL, 1988), precisa compreender os afetos e respeitar o desejo. Contudo, com base apenas nos seus dogmas conservadores e racionalismo filosófico, o Direito não é capaz de atender a tantas demandas. Os operadores do Direito não se contentam mais com a objetividade da ordem legal e da doutrina jurídica. Sentem que há

\footnotetext{
${ }^{138}$ DERRIDA, J. Força de lei: o fundamento místico da autoridade.São Paulo: WMF Martins Fontes, 2010, p. 55.

${ }^{139}$ BOBBIO, Noberto. Direito e Estado no pensamento de Emanuel Kant. $4^{\mathrm{a}}$ Ed. Trad. Alfredo Fait. Brasília: UnB, 1997, p. 349.
} 
algo oculto, por trás e tal como o analisando, premidos pelos sintomas batem à porta da Psicanálise para melhor compreender a subjetividade humana. Afinal, que outro saber, firmado na ética do desejo e no primado da alteridade, permitiria alcançar este objeto, senão a Psicanálise ? ${ }^{140}$

Sobre o tema, ninguém mais adequado do que Sigmund Freud. O referido autor, em 1913, escreveu o artigo "O Interesse Científico da Psicanálise”, que se divide em duas partes, a primeira intitulada “ $O$ Interesse Psicológico da Psicanálise” e a segunda parte "O Interesse da Psicanálise para as Ciências Não-Psicológicas”. Neste segundo texto, Freud relacionou as contribuições oferecidas pela Psicanálise aos demais campos do saber, quais sejam: Filosofia, História, Biologia, Educação, Sociologia e Artes. No texto, Freudpassa a demonstrar a referida teoria como ferramenta para melhor compreensão da civilização humana.

Nessa esteira, a relação entre Direito e Psicanálise tem como principal escopo, a busca eterna pela efetivação da Dignidade da Pessoa Humana. Sabe-se que a ciência jurídica está em constante busca da compreensão de seus próprios institutos. Nessa busca, a ciência jurídica procura agregar embasamento e conhecimento através do estudo de outras áreas do saber, entre elas a Psicanálise.

É na interseção com a Psicologia e a Psicanálise, que o Direito busca avançar ainda mais no desenvolvimento de nossa sociedade cada vez mais plural, dinâmica e que necessita incessantemente de respeito às diferenças. O surgimento da Psicanálise e o estudo do inconsciente tiveram particular influência nas ciências sociais e humanas e o Direito não poderia ficar ileso. ${ }^{141}$

RODRIGO DA CUNHA PEREIRA diz que "o inconsciente produz efeitos e é exatamente a partir desses efeitos que ele é reconhecido - lapso, ato falho... Efeitos que, embora inconscientes, repercutem no Direito". ${ }^{142}$

\footnotetext{
${ }^{140}$ BRAGA, Julio Cezar de Oliveira. Do interesse da Psicanálise para o Direito na contemporaneidade. Disponivel

em <http://www.uff.br/periodicoshumanas/index.php/ecos/article/viewFile/1028/825> . Acesso em 19 out. 2015.

${ }^{141}$ VIEGAS, Cláudia Mara de Almeida Rabelo. O papel da mediação e da psicanálise para o direito de família. Disponível em <http://www.ambitojuridico.com.br/site/index.php?n_link=revista_artigos_leitura\&artigo_id=9270> Acesso em 21 out. 2015.

${ }^{142}$ PEREIRA, Rodrigo da Cunha. Prefácio. In: GARCIA, Célio. Psicologia Jurídica: operadores do simbólico. Belo Horizonte: Del Rey, 2004.
} 
A Psicanálise veio demonstrar que a objetividade dos fatos e atos jurídicos está permeada por uma subjetividade que o Direito não pode mais desconsiderar.

A bem da verdade, o Direito e a Psicanálise se mostram presentes em todos os momentos da vida do homem. Enquanto que o Direito atua nas consequências e repercussões na sociedade causadas pelosatos do homem, a Psicanálise busca desvendar os impulsos que antecedem aos atos, procurando se alcançar a razão que deu origem aos mesmos.

Para GROENINGA, "cabe aos psicanalistas sensibilizar os que lidam com o Direito para as questões de família, permitindo uma compreensão mais ampla dos conflitos e do sofrimento". ${ }^{143}$

Freud, em seu texto "Totem e tabu", escreveu que não há necessidade de se proibir algo que ninguém deseja, ou seja, se algo é proibido é porque é desejado. Assim, para toda lei existe um desejo contraposto a ela.

Consequentemente, o Direito de Família, que é um ramo autônomo e independente e permeado por questões subjetivas e internas dos indivíduos, sofre repercussões. A primeira lei criada é uma lei do Direto de Família: proibição do incesto. Tal lei jurídica, como todas as demais, é um interdito proibitório dos impulsos inviabilizadores de um bom convívio social, sendo necessária para a existência de uma organização social.

Ao falar em Direito de Família, percebe-se que esse ramo do Direito é permeado, em sua essência, pela afetividade humana. Não por outra razão, a técnica de escuta e o diálogo são extremamente apropriadas e relevantes para a resolução dos conflitos inerentes às relações familiares. Nesse sentido, tais técnicas devem ser valorizados por todos os operadores do direito, como os advogados, juízes e promotores.

Em se tratando de problemas afetivos, a teoria psicanalítica trouxe uma revolução tanto na concepção desses problemas como no tratamento

\footnotetext{
${ }^{143}$ GROENINGA, Giselle Câmara. Direito e psicanálise: um novo horizonte epistemológico. In: PEREIRA, Rodrigo da Cunha (coord.) Afeto, ética, família e o novo Código Civil. Belo Horizonte, Del Rey, 2004, p. 144.
} 
dos mesmos. A Psicanálise, como será melhor esclarecido, revela grande interesse pela motivação do inconsciente, pelo comportamento anormal, pela personalidade e pelo desenvolvimento infantil.

É comum o indivíduo trazer uma demanda jurídica com pedidos objetivos, como divórcio consensual ou litigioso, pensão alimentícia,guarda dos filhos, visitas, divisão de bens e cabe ao Judiciário encontrar uma solução queregulamente à convivência familiar. A Psicanálise, por sua vez, proporciona um tipo de escuta que leva o sujeito a refletir sobre suas queixas, e a se responsabilizar por elas, desconstruindo o cenário de vitimização para protagonização do conflito.

Nesse contexto, sabe-se que a visão do sujeito pelo Direito é diversa da visão da Psicanálise. O mal-estar e o conflito são enxergados de modo diverso por ambos os institutos. De acordo com SOUZA, o sujeito jurídico é visto como aquele detentor do livre arbítrio e da razão, aquele que tem consciência de seus atos e é capaz de controlar suas vontades, discernindo o que é proibido e o que é permitido. ${ }^{144}$

Certo é que para se viver em sociedade é necessário que os homens tenham que se submeter às leis, que geram restrições, porém se algoescapa, se instaura o mal-estar e o conflito.

As leis foram impostas em nossa sociedade com a finalidade de estabelecer normas para uma boa convivência com as pessoas que nos rodeiam. Entretanto na grande maioria das vezes acabamos por nos tornar dependentes e submissos a ela. Se existe a lei é porque existe o desejo. ${ }^{145}$

Diante do desejo e da lei que se encontra o diálogo de intercessão do Direito e da Psicanálise. Fato é que a Psicanálise se revela de grandíssima relevância para o Direito, sobretudo quando se trata de descumprimento de

\footnotetext{
${ }^{144}$ SOUZA, Ivone M. C. Coelho de. Mediação em Direito de Família - um recurso além da semântica. In: Revista Brasileira de Direito de Família. v. 27, Porto Alegre: Síntese, 2005, p.2939.

${ }^{145}$ VIEGAS, Cláudia Mara de Almeida Rabelo. O papel da mediação e da psicanálise para o direito de família. Disponível em <http://www.ambitojuridico.com.br/site/index.php?n_link=revista_artigos_leitura\&artigo_id=9270> Acesso em 25 out. 2015.
} 
deveres subjetivos como os previstos no Direito de Família.

Pelo exposto, a Psicanálise pode e deve ser utilizadade forma ampla no âmbito do Judiciário, a fim de promover discussões e questionamento e até mesmo a possibilidade de uma eventual intervenção na estrutura familiar e social do sujeito envolvido em conflitos.

\subsection{A Proposta da Psicanálise: a Subjetivação da Responsabilidade}

Muito diferente das implicações da condenação indenizatória pelo abandono afetivo ao filho abandonado, a Psicanálise desvenda os reflexos dessa responsabilização ao pai abandônico.

Freud desvenda o inconsciente ao mundo e anuncia que o "eu deixou de ser senhor da sua própria casa", querendo se referir à instância enigmática, incontrolável e desconhecida como determinante das relações do sujeito com o outro. Ao desvendar o inconsciente, Freud supõe que o homem estaria isento de qualquer responsabilidade pelos seus atos, já que esses seriam resultado de ações incontroláveis do inconsciente.

Assim, os atos do sujeito inserido no inconsciente se mostram, para Freud, como sendo livres de quaisquer responsabilidades, na medida em que são encarados através da acepção de inconsequente.

Freud, após afastar a noção de responsabilidadeem sua obra inicial "A interpretação dos sonhos" (1900), publica a sua obra intitulada de "Algumas notas adicionais sobre interpretação dos sonhos como um todo", em 1925, composta por três notas, onde melhor explica tal dinâmica.

$\mathrm{Na}$ segunda nota da referida obra, denominada "A responsabilidade moral pelo conteúdo dos sonhos", Freud questiona e responde, ao mesmo tempo, se o homem deve assumir a responsabilidade pelo conteúdo de seus sonhos.

Ainda que a noção de responsabilidade não tenha sido objeto de abordagem mais profunda na obra freudiana, no mínimo que Freud se dedicou àquela, tomando o sonho como paradigma para as demais 
formações do inconsciente, se mostra decisivo para a conclusão de que a Psicanálise não afasta a responsabilidade do sujeito por força de seu inconsciente. Conforma se lê em Freud:

Se olharmos para os desejos inconscientes reduzidos à sua mais fundamental e verdadeira forma, teremos de concluir, fora de dúvida, que a realidade psíquica é uma forma especial de existência que não deve ser confundida com a realidade material. Desse modo, não parece haver justificativa para relutância das pessoas em aceitar a responsabilidade pela imoralidade de seus sonhos. $[\text { Grifou-se }]^{146}$

Através disso, Freud explica que ainda que não se possa ter controle sobre o inconsciente e que a autonomia da vontade seja relativa, a responsabilidade do sujeito por todos seus atos ou sonhos é existente.

Freud e os psicanalistas, nesse sentido, fornecem importância para a culpa, ou seja, entendem que culpa inconsciente se caracteriza por uma falta ignorada pelo sujeito.

Entende-se que a culpa faz parte do sujeito, sendo o elemento que permite ao sujeito assumir as consequências do seu ato de delito. Para a Psicanálise, a culpa é o registro da falta na subjetividade, é o entendimento de que se existe limite ao qual é preciso ser respeitado, não somente ao mundo exterior, como também para si mesmo.

GEREZ - AMBERTIN, ao citar Lacan, sustenta que não é possível pensar na estrutura do sujeito sem que se tenha em consideração a culpa como algo onipresente. Para ela, a extinção da culpa pressupõe a dissolução da subjetividade

JULIO CEZAR DE OLIVEIRABRAGA, ao citar AMBERTÍN explica bem o conceito:

A culpa inconsciente é uma falta ignorada pelo sujeito, e o sujeito não pode escapar da responsabilidade de interrogar sobre esta falta, porque ainda que ignorada provoca mal-estar, remorsos, vergonhas, inibições, autoacusações, atos impulsivos incompreendidos, crimes imotivados. Interrogar a este malestar com o outro e na transferência supõe a intenção de que esta falta ignorada se torne negociável pelo significante. Tal responsabilidade com consentimento

\footnotetext{
${ }^{146}$ FREUD, Sigmund. O Ego e o Id e outros trabalhos. Ed. Standard Brasileira das Obras Psicológicas Completas de Sigmund Freud. Rio de Janeiro: Imago, 1976.
} 
subjetivo que cabe ao sujeito do inconsciente freudiano. Neste sentido, a culpa para a psicanálise está ligada à responsabilidade e o sujeito não pode depreenderse dela. [Grifou-se] ${ }^{147}$

Outro relevante ponto destacado nessa área da Psicanálise é a diferenciação entre a responsabilização e a imputação de uma culpa. A responsabilidade, como resposta pelas próprias ações ou pelas de outros, difere do alcance conceitual de imputação, que segundo ABBAGNANO, possui significado moral, como "juízo em virtude do qual alguém é considerado como autor (causa livre) de uma ação que está submetida a leis e se chama fato". ${ }^{148}$

Em termos psicanalíticos, para que o sujeito seja responsabilizado efetivamente é preciso fazer valei a Lei, não somente aquela do registro objetivo, do lado de fora, mas principalmente pela sua subjetivação, para que então se opere a submissão aos limites impostos pela cultura, possibilitando a inclusão do sujeito e do outro no laço social. ${ }^{149}$

A principal contribuição da Psicanálise para o Direito é o entendimento de que o castigo não se mostra como a solução mais eficaz. É importante que se vá além do castigo, ou seja, não é que não seja possível haver pena, mas para que uma penalidade tenha eficácia é preciso que ela passe do externo para o interno.

Dentro do interior do sujeito que a responsabilidade passará a dar sentido a penalidade. Sendo assim, o castigo decorrente da responsabilização advinda do mundo externo somente ganhará valor se assentido pelo sujeito que foi penalizado.

Por isso, diferentemente do Direito, em que o Poder Judiciário acaba por responder pelo sujeito, a Psicanálise entende que o sujeito se oferece como resposta para as suas próprias questões.

No caso do abandono afetivo e sua solução através da resposta indenizatória pelo Poder Judiciário, se percebe que a condenação judicial não conduz, necessária e obrigatoriamente, à responsabilização do sujeito.

\footnotetext{
${ }^{147}$ AMBERTÍN, 2006, p. 46 apud BRAGA, Julio Cezar de Oliveira, 2014, Op. cit., p. 192-193.

${ }^{148}$ ABB AGNANO, Nicola. Dicionário de Filosofia. São Paulo: Martins Fontes, 1998, p. 855.

${ }^{149}$ BRAGA, Julio Cezar de Oliveira. Op. cit., p. 200.
} 
O que pode ocorrer é justamente o contrário, ou seja, levar a desresponsabilização, em que o pagamento pecuniário afasta a possiblidade de se subjetivar o ato ou a omissão. Como se o afeto ficasse quitado como ficou quitada a dívida imposta.

Tem-se que a condenação por danos morais culpabiliza o pai que não deseja ou não manifesta afeto pelo filho, não tem, porém, o condão de, por si só, conduzir a sua responsabilidade efetiva para o restabelecimento do laço afetivo, tampouco seria capaz de compensar qualquer ausência afetiva.

Quando se fala em comportamento e conduta humana, bem como em responsabilidade do sujeito perante si próprio e perante ao outro, alcança-se o campo profundo da ética.

A ética se perfaz através de uma noção eminentemente filosófica, sendo visitada pela Psicanálise. Como o conceito de ética advém da filosofia, um saber focado na consciência, se questiona qual seria a sua importância para o mundo da Psicanálise, já que essa última se centra no inconsciente.

Assim, para a Psicanálise, a ética recebe importância quando se quer investigar a subjetividade e as relações de alteridade que habita o psiquismo. A ética, portanto, serve como fonte de estudo para a compreensão da conduta humana, sendo ela, um limite crítico para essa última.

\subsection{A Ética Afetiva como Limite à Conduta Humana}

A noção de afeto entra no campo da ética e do Direito com uma grande relevância para a compreensão mais efetiva da conduta humana. O Direito e a ética enxergaa norma como sendo a figura mais importante e, consequentemente, a interdição ao desvio.

Deve-se entender que o afeto é o que antecede a norma, ou seja, onde falha $o$ afeto, urge-se a lei. 
No âmbito das éticas baseadas na individualidade, o afeto é invocado como fundamento da ação moral, ou seja, é o capacitor da empatia e de tolerância.

Se a lei moral e o ditame do Direito forem chamados para dirimir conflitos, supõe-se que faltou, por ambos os lados da demanda, a capacidade de sentir como o outro, de se colocar no lugar do outro. Nessa diapasão, é possível dizer que faltou afeto.

A questão do afeto merece atenção, pois pela dificuldade que temos de reconhecer nossas características agressivas, nós, através do senso comum e talvez pela herança filosófica, tendemos a equiparar o amor ao afeto, idealizando, muitas vezes, a família como um reduto apenas de amor. Sabe-se, porém, que a família se revela como muito maior do que apenas amor, sendo um meio de construção liberal da individualidade de cada qual.

GROENINGA e PEREIRA, citando Freud, explicam que:

\begin{abstract}
A evidência trazida pela psicanálise demonstra que quase toda a relação emocional íntima entre duas pessoas, que dura algum tempo - casamento, amizade, as relações entre pais e filhos - contém sedimento de sentimentos de aversão e hostilidade, que somente escapa da percepção como resultado da repressão. Isto está menos disfarçado nas disputas comuns entre parceiros de negócios ou em resmungos de um subordinado com seu superior. O mesmo ocorre quando os homens se reúnem em unidades maiores. ${ }^{150}$
\end{abstract}

Nessa esteira, a ética afetiva se revela como o meio limitador da conduta humana, já que sem é fundamento da ação moral e permeia a criação dos filhos pelos pais.

A virada do século XX caracteriza-se pela quebra de uma estrutura milenar ao romper a ideologia patriarcal. Nessa antiga ideologia patriarcal, os lugares de mãe, pai e filho são bastante demarcados e rígidos. Com o rompimento dessa ideologia, os lugares estruturantes dos sujeitos, enquanto função, passam a serem alterados, causando consequências na formação das famílias da atualidade.

\footnotetext{
${ }^{150}$ FREUD, Sigmund. Group psychology and the analysis of the ego.Vol. XIII, p. 101. In: GROENINGA, Giselle Câmara; PEREIRA, Rodrigo da Cunha. Direito de família e psicanálise: rumo a uma nova epistemologia. Rio de janeiro: Imago, 2003, p. 131.
} 
Uma das maiores e mais claras consequências do referido declínio do modelo patriarcal é o redimensionamento do masculino e da função paterna no novo contexto pós-patriarcalismo. Podemos falar hoje em uma crise da paternidade, diante das novas representações sociais da família.

A ausência das funções paternas é alarmante e ela se asseverou com a revolução feminista, onde houve a redivisão sexual do trabalho e a consequente queda do patriarcalismo. Aqui se fala em um menor esforço de ambos os pais, pai e mãe, de atenderem os anseios de seus filhos, já que o mercado de trabalho se mostra muito mais atraente e chamativo.

A inserção da mulher no mercado de trabalho é algo de muita valia e deve ser motivo de orgulho para a sociedade, mas uma de suas consequências é o abandono moral do menor. Se ambos os pais competem espaços iguais no mercado, não há como se fornecer à prole a devida atenção que lhe é devida.

O desafio do terceiro milênio será a aprendizagem da organização da polis, devendo o Estado ser pensado através de seu núcleo básico que é a família. Teremos que aprender, diante desse novo contexto e essas novas formas de família, como lidar e reverter a ausência dos pais em relação aos filhos, na medida em que essa, como já é sabido, se mostra por demais danosa a estrutura do sujeito.

Nessa medida, a ética afetiva se revela como sendo um limite à conduta dos pais em relação aos seus filhos. O entendimento de que a realização pessoal não deve acabar por significar ausência na criação da prole é imprescindível para a efetiva organização da polis, sob pena de um caos completo. 
Junto com a Constituição Federal de 1988, incontestáveis alterações para o exercício do poder familiar foram importadas para o ordenamento jurídico pátrio. Se observa que o poder familiar não mais vislumbra apenas direitos, mas inúmeros deveres em relação a prole.

Fato é que dentre esses deveres decorrentes do poder familiar, há o dever se assistência moral aos filhos. Através desse entendimento, a conduta de abandono afetivo é, consequentemente, enxergada como contrária ao Direito, sendo eivada de ilicitude.

É certo que o abandono afetivo sempre esteve presente em todos os lugares e tempos, sendo vislumbrado inclusive em passagens bíblicas e regulamentado no Código de Hamurabi. Assim, não se revela como sendo fenômeno da atualidade, tampouco decorrente das alterações conceituais da família.

Como visto no presente trabalho, o conceito de família foi alterado com o tempo. A família passou a ser encarada como base da sociedade, sendo capaz de oferecer às crianças e adolescentes um ambiente propício para a efetiva formação intelectual e psíquica. Sabe-se que um dos responsáveis pela alteração conceitual e prática do instituo família foi justamente o afeto.

$\mathrm{O}$ afeto se mostra com sendo uma figura primordial para a construção da individualidade do ser humano. Nesse contexto, unindo a ideia de que a família deve ser um ambiente acolhedor e propício para o desenvolvimento dos menores com a ideia de que o afeto é fundamental para a formação da individualidade do ser humano, nada mais óbvio do que se exigir dos pais a afetividade para com sua prole.

Aqui não se trata de amor, mas de afeto. $\mathrm{O}$ afeto deve ser encarado como um princípio constitucional, decorrente do princípio basilar da dignidade da pessoa humana, devendo ser visto como um direito 
fundamental da personalidade. Juntamente com o princípio da afetividade, há o princípio da paternidade responsável, esse encarado como obrigação legal decorrente da parentalidade.

As consequências da conduta de abandono afetivo são reconhecidamente devastadoras para quem sofre. Muitas vezes, os maus tratos são levados de forma menos danosa em relação à ausência de trato.

Assim, apesar de, a princípio, o abandono afetivo não aparentar fornecer o mesmo risco de vida a que os maus tratos e o castigo físico submetem a criança ou o adolescente, há diversas implicações no psiquismo do indivíduo que podem acarretar consequências muito mais graves à formação do ser humano. Não raro, portanto, o castigo físico se mostra como infinitamente menor diante do castigo que é submetido aquele que é vitima do abandono afetivo.

O abandono afetivo representa a descrença no outro, simboliza o desinteresse, a falta de desejo e remete, ao final, o desamparo. As consequências de tal conduta, como já explicitado, são devastadoras e podem implicar na malcriação do psiquismo e do caráter daquele que sofre.

Nesse contexto, diante das alterações conceituais do instituto da família e diante das agressivas consequências do ausência afetiva, o tema guarda controvérsia acerca da responsabilidade civil dos pais que praticam a conduta ilícita do abandono afetivo.

A possibilidade de se vislumbrar a reparação do dano decorrente do abandono afetivo surge a partir da evolução da responsabilidade civil aplicável às relações familiares. Essa evolução se deu com passar dos tempos e de forma gradual, já que antigamente não havia espaço para a discussão acerca da responsabilidade civil no âmbito do direito de família.

Se enxergava as relações do âmbito familiar como sendo intocáveis e pessoais, de modo que normas jurídicas não podiam alcança-las. Nesse sentido, por bastante tempo se entendeu que as regras da responsabilidade civil não eram cabíveis nas relações familiares.

Ao Direito de Família se aplicavam apenas regras próprias, não 
sendo cabíveis as regras gerais do Direito, como por exemplo o dever de reparação em caso de dano.

Com o decorrer do tempo, entretanto, em função de uma nova ordem econômica e social, as relações familiares passaram a sofrer incidência das regras da responsabilidade civil, bastando, para tanto, que se estivessem presentem os requisitos gerais para a sua aplicação. São eles: (i) conduta ilícita; (ii) dano e (iii) nexo causal.

Portanto, a responsabilidade civil no Direito de Família tem como objetivoproteger os direitos fundamentais dos membros, exigindo a assistência integral dos pais aos seus filhos e prevendo a possibilidade de reparação do dano em eventual conduta ilícita.

A responsabilidade civil decorre de uma série de obrigações imputadas pelo poder familiar. De fato, o poder familiar vislumbra diversos deveres-poderes que devem ser desempenhados de modo a efetivar o princípio do melhor interesse da criança, sempre com o intuito de garantir o pleno e melhor desenvolvimento da prole.

A Constituição Federal, em seu artigo 227, ao dispor sobre direitos da criança e do adolescente, afirma o direito à convivência familiar, atribuindo-a como dever da família, da sociedade e do Estado.

Pois bem, é dever dos pais ter os filhos em sua companhia, dirigirlhes a criação e a educação, como reza o artigo 1.634, incisos I e II, do Código Civil. O Estatuto da Criança e do Adolescente, em diversos dispositivos, prevê o desenvolvimento pleno e sadio da criança e do adolescente como sendo um direito fundamental do menor.

Nesse sentido, diante da previsão legislativa constitucional e infraconstitucional que circunda os deveres imputados ao poder familiar, a conduta de desassistência afetiva se revela como contrária ao ordenamento e o dano causado em consequência é claro e conhecido. Plenamente aplicável, pois, o instituto da responsabilidade civil para os casos de abandono afetivo dentro das relações familiares. 
A controvérsia, porém, resideno fato de a legislação não ser capaz de acompanhar a velocidade das alterações sociais e, por isso, não prevê expressamente os liames da responsabilidade civil aplicável aos casos de abandono afetivo. Ao mesmo passo em que o afeto é resguardado pela legislação e claramente passível de punição, não se vislumbra de forma expressa qual a forma de punição adequada, tampouco as hipóteses para o seu cabimento.

Por isso, diante da lacuna legislativa, se mostrou necessária a intervenção do Poder Judiciário para que avalie cada caso e a aplicação do instituo de forma geral. Ao trazer tais demandas ao Poder Judiciário, houve a jurisdicização do afeto e a sua consequente patrimonialização. A jurisdicização é fenômeno natural e lógico, mas a sua patrimonialização guarda debates fervorosos que foram tratados no presente trabalho.

No mesmo sentido, sabe-se que casos que envolvam conflitos familiares guardam consigo questões subjetivas e internas, sendo de grande responsabilidade dos julgadores a correta análise do caso concreto.

Além do caminhar feito pelo Poder Judiciário, há o esforço do Poder Legislativo em ver a conduta abandônica efetivamente punida. Com o intuito de ver punida tal conduta, dois projetos de lei foram criados. O primeiro deles, o Projeto de Lei nº 700/2007 de autoria do Senador Crivella, prevê não somente a responsabilização, como também a criminalização com pena privativa de liberdade dos pais que deixarem de prestar assistência moral, alterando artigos do ECA.

O segundo, é o Projeto de Lei $n^{\circ}$ 4.294-A/2008 acaba por responsabilizar também o filho que priva os pais da dedicação afetiva, prevendo, assim, uma nova visão do instituto.

Além de ambos projetos, há ainda o grande Projeto de Lei $\mathrm{n}^{\circ}$ 470/2013, denominado de Estatuto das Famílias. O abandono afetivo é considerado na referida proposição como conduta ilícita. A proposta legislativa conceitua a prática do abandono afetivo como qualquer ação ou 
omissão que ofenda direito fundamental da criança ou do adolescente, entre eles a convivência familiar saudável.

Ainda em sede de tentativa de regulamentação do tema do abandono afetivo, o IBDFAM aprovou, em 2013 e 2015, dois enunciadosno sentido de prever a possibilidade de reparação pelo dano causado em decorrência da conduta abandônica, bem como a previsão de possiblidade de reconhecimento do abandono afetivo em relação aos ascendentes idosos.

Tais enunciados se revelam como uma tendência da doutrina e da jurisprudência do Direito de Família, possibilitando a pacificação do entendimento pela possiblidade do arbitramento de danos morais pelo abandono afetivo e, inclusive, a ampliação do instituto, já que prevê o reconhecimento do abandono afetivo em relação aos ascendentes idosos.

O presente trabalho propôs, ainda, a melhor via para a solução do conflito que envolve pais e filhos em relação de desassistência afetiva, prevendo a mediação como a mais adequada. Isso porque, a mediação é uma relevante técnica de solução consensual de conflitos que objetiva a facilitação do diálogo entre os mediados, para que, por si só, alcancem uma solução de benefício mútuo e sustentável no tempo, preservando os vínculos relacionais e discutindo não apenas das questões objetivas, mas das subjetivas.

Por fim, em uma visão interdisciplinar, foi feita uma analise crítica dos pontos de intercessão e ruptura entre o Direito e a Psicanálise no que se refere a conduta humana. O diálogo entre as duas áreas do saber reside no ponto de intercessão entre o desejo e a lei.

A ruptura, por sua vez, se encontra no entendimento de que a solução mais eficaz não se dá através do castigo externo, como a pena, mas do interno para o externo. Assim, para que uma penalidade tenha eficácia é preciso que ela se transporte do âmbito externo para o âmbito interno.

A ética afetiva também é de grande contribuição para o tema, pois ela é capaz de limitar a conduta humana. Atualmente, o homem está centrado muito em seus próprios interesses e é necessário que se doe ao 
outro de forma plena. Esse cenário é bem encarado pela atual rotina dos pais. Os pais trabalham a maior parte do tempo para serem bem sucedidos e acabam por pecar na educação e nas demonstrações de afeto com sua prole.

Nessa medida, a ética afetiva se mostra como um limite à conduta dos pais em relação aos seus filhos, na medida em que cabe aos pais entenderem que a realização pessoal não deve prejudicar criação da prole. Dependendo dessa criação, que será determinada a efetiva organização da sociedade.

Portanto, como visto, o tema do abandono afetivo guarda diversas controvérsias não apenas em seu conteúdo teórico, mas sobretudo quando aplicado em casos concretos e julgados pelos nossos tribunais

O presente trabalho buscoua discussão acerca do abandono afetivo e da relevância do afeto para a construção da individualidade de cada ser humano. 


\section{BIBLIOGRAFIA}

\section{Livros:}

ABBAGNANO, Nicola. Dicionário de Filosofia. São Paulo: Martins Fontes, 1998.

ALMEIDA, Renata Barbosa de; RODRIGUES JÚNIOR, Walsir Edson. Direito civil: famílias. Rio de Janeiro: Lumen Juris, 2010

BARBOSA, Águida Arruda. Prática da mediação: ética profissional. In: PEREIRA, Rodrigo da Cunha (Coord.). Família e dignidade humana. Anais do V Congresso Brasileiro de Direito de Família. Rodrigo da Cunha Pereira. 2006.

BARROSO, Luís Roberto. Curso de Direito Constitucional contemporâneo. São Paulo: Saraiva, 2009.

BOBBIO, Noberto. Direito e Estado no pensamento de Emanuel Kant. $4^{\mathrm{a}}$ Ed. Trad. Alfredo Fait. Brasília: UnB, 1997.

BRAGA, Julio Cezar de Oliveira. Abandono afetivo: do Direito à Psicanálise. Rio de Janeiro: Lumen Juris, 2014

BRANCO, Bernardo Castelo. Dano moral no Direito de Família. São Paulo: Método, 2006.

BRANDÃO, Wilson de Andrade. Divórcio e separação judicial. 3 ed. Rio de Janeiro: Freitas Bastos, 1991. 
BUENO, Cassio Scarpinella. Curso sistematizado de Direito Processual Civil. 6ed. São Paulo: Saraiva, 2012. vol. 1.

CALDERÓN, Ricardo Lucas. Princípio da afetividade no Direito de Família. Rio de Janeiro: Renovar, 2013.

CALIXTO, Marcelo Junqueira. A culpa na responsabilidade civil: estrutura e função. Rio de Janeiro: Renovar, 2008.

CÂMARA, Alexandre Freitas. Lições de Direito Processual Civil. 17 ed. Rio de Janeiro: Lumen Juris, 2008, v. I.

CARDIN, Valéria Silva Galdino. Dano moral no Direito de Família. São Paulo: Saraiva, 2012.

CAVALIERI FILHO, Sérgio. Programa de responsabilidade civil. 10 ed. São Paulo: Atlas, 2012.

CHAVES, C; ALVES, L. B. M; ROSENVALD, N. Temas atuais do Ministério Público: a atuação do "Parquet" nos 20 anos da Constituição Federal. Rio de Janeiro: Lumen Juris, 2010..

CODO, W.; GAZZOTTI, A. A. Trabalho e afetividade. In: CODO, W. (Coord.). Educação: carinho e trabalho. 3. ed. Petrópolis: Vozes, 1999.

COMEL, Denise Damo. Do poder familiar. São Paulo: Revista dos Tribunais, 2003.

DERRIDA, J. Força de lei: o fundamento místico da autoridade. São Paulo: WMF Martins Fontes, 2010. 
DEUTSCH, Morton. The resolution of conflict: constructive and destructive processes. New Haven: Yale University Press, 1973 apud ALMEIDA, D. A. R.; PANTOJA, F. M.; PELAJO, S. (Coords.). A mediação no novo Código de Processo Civil. Rio de Janeiro: Forense, 2015.

DIAS, Maria Berenice. Manual de direito das famílias. $8^{a}$ Edição. Revista, atualizada e ampliada. São Paulo: Editora Revista dos Tribunais, 2011.

DINIZ, Maria Helena. Curso de Direito Civil brasileiro: responsabilidade civil. 19 ed. São Paulo: Saraiva, 2005

FARIAS, C. C; ROSENVALD, N. Direito das famílias. 2 ed. Rio de Janeiro:Lumen Juris, p.9, 2010.

FREUD, Sigmund. Group psychology and the analysis of the ego.Vol. XIII, p. 101. In: GROENINGA, Giselle Câmara; PEREIRA, Rodrigo da Cunha (Coord.). Direito de família e psicanálise: rumo a uma nova epistemologia. Rio de janeiro: Imago, 2003,

Sigmund. $O$ Ego e o id e outros trabalhos. Ed. Standard Brasileira das Obras Psicológicas Completas de Sigmund Freud. Rio de Janeiro: Imago, 1976.

GAGLIANO, Pablo Stolze; PAMPLONA FILHO, Rodolfo. Novo curso de Direito Civil - Direito de Família. vol. VI, $1^{\text {a }}$ ed. Rio de Janeiro: Saraiva, 2011.

GONÇALVES, Carlos Roberto. Direito Civil brasileiro - Direito de Família. Vol. 6. $12^{\circ}$ Ed. Rio de Janeiro: Saraiva, 2015. 
, Carlos Roberto. Direito Civil brasileiro. 3. ed. rev. e atual.

São Paulo: Saraiva, 2008. v. IV

GROENINGA, Giselle Câmara. Direito e Psicanálise: um novo horizonte epistemológico. In: PEREIRA, Rodrigo da Cunha (Coord.) Afeto, ética, família e o novo código civil. Belo Horizonte, Del Rey, 2004.

KAROW, Aline Biasuz Suarez. Abandono afetivo: valorização do afeto nas relações paterno-filiais. Curitiba: Juruá, 2012.

LENZA, Pedro. Direito constitucional esquematizado. 7. Ed. São Paulo: Método, 2004.

LIMA, Taisa Maria Macena de. Responsabilidade civil dos pais por negligência na educação e formação escolar dos filhos: o dever dos pais de indenizar o filho prejudicado. In: PEREIRA, Rodrigo da Cunha (Coord.). Afeto, ética, família e o novo Código Civil. Belo Horizonte: Del Rey, 2004.

, Evandro Souza e; PELAJO, Samantha. A mediação nas ações de família. In: ALMEIDA, D. A. R.; PANTOJA, F. M.; PELAJO, S. (Coords.). A mediação no novo Código de Processo Civil. Rio de Janeiro: Forense, 2015.

LÔBO, Paulo Luiz Netto. Código Civil comentado. São Paulo: Atlas, 2003. , Paulo. Direito civil: famílias. 4. ed. São Paulo: Saraiva, 2011.

MADALENO, Rolf. A guarda compartilhada pela ótica dos direitos fundamentais. In, WELTER. Belmiro Pedro; MADALENO, Rolf (Coord). Direitos Fundamentais do Direito de Família. Porto Alegre: Livraria do Advogado, 2004, 
MENDES. M. U. Vindo e indo. In: MORATO, H. T. P; BARRETO, C. L. B. T; PRADO, A. N. Rio de Janeiro: Guanabara Koogan, 2009.

MORAES, Maria Celina Bodin de. Recusa à realização do exame de DNA na investigação de paternidade e direitos da personalidade. A nova família: problemas e perspectivas. Coordenador: BARRETO, Vicente. Rio de Janeiro: Renovar, 1997.

OLIVEIRA, José Sebastião de.Fundamentos constitucionais do Direito de Família. São Paulo: Revista dos Tribunais, 2002.

PEREIRA, Rodrigo da Cunha. Prefácio. In: GARCIA, Célio. Psicologia jurídica: operadores do simbólico. Belo Horizonte: Del Rey, 2004.

PEREIRA, Tânia da Silva. O Cuidado como valor jurídico. In: A ética da convivência familiar: sua efetividade no quotidiano dos Tribunais. Tânia da Silva Pereira e Rodrigo da Cunha Pereira (coords.). Rio de Janeiro: Forense, 2006.

SALES, Lília Maia de Morais. Mediação de conflitos: família, escola e comunidade. Florianópolis: Conceito Editorial, 2007.

SE $\square$ DA, Edson. Construir o passado. São Paulo: Malheiros, 1993.

VALDEZ, Diane. Inocentes expostos: o abandono de crianças na íncia de Goiás no século XIX. Rev. Fac. Educ. UFG, 29 (I), 2009.

VENOSA, Sílvio de Salvo.Direito civil. Direito de Família. 7. ed. São Paulo: Atlas, 2007. 


\section{Teses e Artigos:}

ALMEIDA, Ena Nunes de, et al.. Os maus tratos às crianças na família. Acta Médica Portuguesa, Lisboa, nº 15, p. 257-267, 2002.

COL, Helder Martinez da. Contrato de namoro. Revista Brasileira de Direito de Família: IBDFAM, Porto Alegre, n. , p.126-156, 01 abr. 2004.

FERREIRA, Lucia Maria Teixeira. As políticas públicas e o Ministério Público como agentes garantidores do direito à convivência familiar e comunitária de crianças e adolescentes. Revista do advogado, São Paulo, v. 28, n. 101, dez. 2008, p. 65.

MOREIRA, Lívia Alves. A Judicialização do afeto: a responsabilidade civil dos pais em relação aos filhos por abandono afetivo. Rio de Janeiro. 2014. 133 p. Dissertação de mestrado - Departamento de Direito a PUCRio. Orientadora: Caitlin Mulholland.

RUBIN, Débora; TEIXEIRA, Paulo César. Pelo direito de ser filho. Revista Época, Rio de Janeiro, 6 de dez. 2004.

SCHUH, Lizete Peixoto Xavier. Responsabilidade civil por abandono afetivo: a valoração do elo perdido ou não consentido. Revista Brasileira de Direito de Família, Porto Alegre, v.8, n.35.

SOUZA, Ivone M. C. Coelho de. Mediação em Direito de Família - um recurso além da semântica. In: Revista Brasileira de Direito de Família. v. 27, Porto Alegre: Síntese, 2005, p.29-39.

TARTUCE, Flávio. Danos morais por abandono moral. Revista Brasileira de Direito das Famílias e Sucessões. Porto Alegre, Magíster; Belo Horizonte: IBDFAM, a. 10, n. 7, p.113, dez./jan. 2009. 
WIECHOREKI, Marlene Sauer. Papel da família, da sociedade e do estado na proteção de crianças e adolescentes. Revista Jurídica Consulex, Brasília, v. 12, n. 286, 15 dez. 2008.

ZAMBELLI, Sara Koshevnikoff. Intervenc $\square$ ão do Estado no poder familiar. Brasília. 2010. 84 p. Monografia de fim de curso - Departamento de Direito do Centro Universitário de Brasília Faculdade de Cie $\square$ ncias Jurídicas e Sociais.

\section{Sites:}

BANDEIRA, Paula Greco. A evolução do conceito de culpa e o artigo 944 do Código $\quad$ Civil. $\quad$ Disponível em $<$ http://www.emerj.tjrj.jus.br/revistaemerj_online/edicoes/revista42/Revista 42_227.pdf>. Acesso em 21 out. 2015.

BRAGA, Julio Cezar de Oliveira. Do interesse da Psicanálise para o Direito na contemporaneidade. Disponível em <http://www.uff.br/periodicoshumanas/index.php/ecos/article/viewFile/102 8/825> . Acesso em 19 out. 2015.

FRANCO, Simone. Alienação parental e abandono afetivo são punidos por estatuto. Disponível

em <http://www12.senado.leg.br/noticias/materias/2014/10/23/alienacaoparental-e-abandono-afetivo-sao-punidos-por-estatuto>. Acesso em 07 out. 2015

IBDAM - Enunciados aprovados pelo IBDFAM. Disponíveis em: $<$ http://www.ibdfam.org.br/noticias/5819/IBDFAM+aprova+Enunciados++ +>. Acesso em 03 de nov. 2015. 
Justificativa de voto da Senadora Lídice da Mata. <http://www12.senado.gov.br/jornal/edicoes/2014/11/06/texto-punealienacao-parental-e-abandono-afetivo/imprimir_materia_jornal>. Acesso em 09 out. 2015.

Justificativa de voto do Dep. Carlos Bezerra. Disponível em $<$ http://www.camara.gov.br/proposicoesWeb/prop_mostrarintegra?codteor= 864558\&filename=Avulso+-PL+4294/2008>. Acesso em 15 out. 2015.

Lei $\quad \mathrm{n}^{\mathrm{o}} \quad 11.340 / 2006 . \quad$ Disponível em $<$ http://www.planalto.gov.br/ccivil_03/_ato20042006/2006/lei/111340.htm>. Acesso em 23 set. 2015.

Lei $\quad \mathrm{n}^{\mathrm{o}} \quad 12.010 / 2009$ Disponível em $<$ http://www.planalto.gov.br/ccivil_03/_ato20072010/2009/lei/112010.htm>. Acesso 25 set. 2015.

LÔBO, Paulo Luiz Netto. Entidades familiares constitucionalizadas: para além do numerus clausus. Disponível em: <http://www.egov.ufsc.br/portal/sites/default/files/anexos/9408-9407-1PB.pdf>. Acesso em 09 set. 2015.

Paulo. Principio Jurídico da afetividade na filiação. In: Jus Navigandi. Terezina. Ano 5, no 41, Maio 2000. Disponível em: <http://jus.com.br/artigos/527>. Acesso em: 09 set. 2015.

MARTÍN, Nuria Belosso. Reflexiones sobre mediación familiar: algunas experiencias en el derecho comparado. Revista Eletrônica de Direito Processual. $2^{\mathrm{a}}$ ed. Disponível em: <www.revistaprocessual.com>. Acesso em 05 out. 2015 
PEREIRA, Rodrigo da Cunha. Responsabilidade civil por abandono afetivo.

<http://www.rkladvocacia.com/arquivos/artigos/art_srt_arquivo201310292 10851.pdf>. Acesso em 14 out. 2015.

Projeto de Lei $\mathrm{n}^{\mathrm{o}}$ 4.294-A/2008. Disponível em $<$ http://www.camara.gov.br/proposicoesWeb/prop_mostrarintegra?codteor= 864558\&filename=Avulso+-PL+4294/2008>. Acesso em 15 out. 2015.

Projeto de Lei $\mathrm{n}^{\mathrm{o}}$ 470/2013. Disponível em <http://www.migalhas.com.br/arquivos/2014/1/art20140109-13.pdf>. Acesso em 08 out. 2015.

Projeto de Lei $\mathrm{n}^{\text {o }}$ 700/2007. Disponível em $<$ http://www.migalhas.com.br/arquivo_artigo/art20100222-04.pdf>. Acesso em 12 out. 2015.

RIBEIRO, Karolyne Moraes. A evolução e os aspectos contemporâneos da responsabilidade civil no Direito de Família. Disponível em $<$ http://www.ambitojuridico.com.br/site/?n_link=revista_artigos_leitura\&artigo_id=10815>. Acesso em 28 set. 2015.

ROMEU JUNIOR, Tuma. Lei da palmada: um tapa na cara da família brasileira! . Disponível em <http://www.migalhas.com.br/dePeso/16,MI204630,41046Lei+da+Palmada+um+tapa+na+cara+da+familia+brasileira>. Acesso em 4 out. 2015.

ROSALINO, Cesar Augusto de Oliveira Queiroz.A gente não quer só dinheiro, a gente quer dinheiro e felicidade:como a patrimonialização do afeto pode interferir nas relações familiare. Disponível em 
$<$ http://jus.com.br/artigos/22080/a-gente-nao-quer-so-dinheiro-a-gentequer-dinheiro-e-felicidade\#ixzz3n2tZxScz>. Acesso em 28 set. 2015.

SALES, Lilia Maia de Morais. Conflitos familiares - a mediação como instrumento consensual de solução. Disponível em http://gajop.org.br/justicacidada/wp-content/uploads/Conflitos-Familiares--A-Mediacao-Como-Instrumento.pdf>. Acesso em 06 out. 2015.

SALOMÃO, Luis Felipe. Momento propício: STJ vai uniformizar jurisprudência sobre abandono afetivo. Disponível em: $<$ http://www.conjur.com.br/2014-abr-08/luis-felipe-salomaostjuniformizar-entendimento-abandono-efetivo>. Acesso em 09 out. 2015.

SANTOS, Pablo de Paula Saul. Responsabilidade civil: origem e pressupostos gerais. Disponível em: <http://www.ambitojuridico.com.br/site/?n_link=revista_artigos_leitura\&artigo_id=11875>. Acesso em 14 set. 2015

SILVA, N. S.; BATISTA, J. P. A Constituição do vínculo na adoção aspectos jurídicos e afetivos. Disponível em $<$ http://Ienomat.Com.Br/Revista/Index.Php/Judicare/Article/View/56/171>. Acesso em 25 set. 2015

VESENTINI, CÍNTIA. Responsabilidade parental: abandono afetivo. Disponível em $<$ http://www.juridicohightech.com.br/2014/04/responsabilidade-parentalabandono.html>. Acesso em 28 set. 2015

VIEGAS, Cláudia Mara de Almeida Rabelo; POLI, Leonardo Macedo. Os efeitos do abandono afetivo e a mediação como forma de solução de conflitos paterno-filiais. Disponível em <http://www.ambito- 
juridico.com.br/site/?n_link=revista_artigos_leitura\&artigo_id=12913>. Acesso em 06 out. 2015.

, Cláudia Mara de Almeida Rabelo. O papel da mediação e da psicanálise para o direito de família. Disponível em <http://www.ambitojuridico.com.br/site/index.php?n_link=revista_artigos_leitura\&artigo_id=9 270> Acesso em 21 out. 2015.

\section{Julgados:}

Decisão do Conselho Superior da Justiça do Trabalho em 03.04.2009, referente ao processo $\mathrm{n}^{0}$ CSJT-150/2008-895-15-00.0. Disponível em $<$ http://www.csjt.jus.br/c/document_library/get_file?uuid=e938572d-79794f8a-a9e9-415116ac0979\&groupId=955023>. Acesso em 01 out. 2015

STJ, $3^{\text {a }}$ Turma, REsp 1159242/SP, Rel. Ministra Nancy Andrighi, j. 24 abr. 2012, DJe 10/05/2012. Disponível em <http://www.stj.jus.br/>. Acesso em 09 out. 2015.

STJ, $4^{\text {a }}$ Turma, REsp 514.350/SP, Rel. Ministro Aldir Passarinho Junior, j. 28 abr. 2009, DJe 25/05/2009. Disponível em <http://www.stj.jus.br/>. Acesso em 09 out. 2015.

STJ, $3^{\text {a }}$ Turma, Resp. 1.304.718 - SP (2011/0304875-5),Rel. Min. Paulo de Tarso Sanseverino. 18 dez. 2014. Disponível em <www.stj.jus.br>. Acesso em 03 set. 2015.

STJ, $4^{\text {a }}$ Turma,Resp. 757.411 - MG (2005/0085464-3), Rel. Min. Fernando Gonçalves. j. 29 nov. 2005. Disponível em <www.stj.jus.br>. Acesso em 10 out. 2015. 
TJRS, Oitava Câmara Cível, Apelação Cível No 70044172401, Rel. Des. Luiz Felipe Brasil Santos, j. 13 out. 2011. Disponível em <http://www.stj.jus.br/>. Acesso em 09 out. 2015.

TJRS, Oitava Câmara Cível, Apelação Cível No 70052059417, Relator: Alzir Felippe Schmitz, Julgado em 07 fev. 2013. Disponível em $<$ http://www.stj.jus.br/>. Acesso em 09 out. 2015.

TJSC, Apelação Cível n. 2011.073787-1, Rel. Des. Jorge Luis Costa Beber, j. 02 ago. 2012. Disponível em <http://www.stj.jus.br/>. Acesso em 09 out. 2015.

TJSC, Apelação Cível n. 2012.005438-5, Rel. Des. Marcus Tulio Sartorato, j. 27- mar. 2012. Disponível em <http://www.stj.jus.br/>. Acesso em 09 out. 2015.

TJSE, $1{ }^{a}$ Câmara Cível, Apelação Cível n. 2012207781,Rel. Des. Suzana Maria Carvalho Oliveira. j. 04 jun. 2012, Data de Publicação: 04/06/2012. Disponível em: <http:/tjse.jusbrasil.com.br/jurisprudencia/21863753/apelacao-civel-ac2012207781-se-tjse>. Acesso em: 09 set. 2015. 